\title{
REGENERAÇÃO DE PLANTAS "IN VITRO" E RADIOSSENSITIVIDADE DE TECIDOS NUCELARES DE CITROS
}

\author{
MOACIR PASQUAL
}

Orientador: Prof. Dr. AKIHIKO ANDO

Tese apresentada à Escola Superior de Agricultura "Luiz de Queiroz", da Universidade de São Paulo, para obtenção do título de Doutor em Agronomia, Área de Concentração: Genética $\theta$ Melhoramento de Plantas.

PIRACICABA

Estado de São Paulo - Brasil

Junho, 1985 
A minha esposa Maria Cristina $e$ aos meus filhos Christiane, Alexander e Leandro

DEDICO 


\section{AGRADECIMENTOS}

As seguintes Instituições, pela oportunidade do curso e fa cilidades no desenvolvimento do trabalho de tese:

- Empresa Catarinense de Pesquisa Agropecuäria S.A. (EMPASC)

- Empresa Brasileira de Pesquisa Agropecuäria S.A. (EMBRAPA)

- Departamento de Genética da Escola Superior de Agricultura "Luiz de Queiroz" (ESALQ)

- Centro de Energia Nuclear na Agricultura (CENA)

- Estacão Experimental de Limeira/Instituto Agronômico de Campinas (IAC)

- A amizade, incentivo, apoio e colaboração de:

Dr. Akihiko Ando

Dr. Otto Jesu Crócomo

Dr. Augusto Tulmann Neto

Dr. José Otávio Machado Menten

Dr. Antonio Natal Gonçalvez

Dr. Joaquim Teófizo Sobrinho

Dr. Carlos Henrique Mattiolzi

Benedita Inês Possignolo Rodrigues

Enio Tiago Oziveira

José Benedito Alves

Paulo Cassieri Neto

- Wlamir de Aguiar Godoy

otávio Minoru Matsumoto

A todos que direta ou indiretamente contribuiram para a rea

lização deste trabalho. 
.ii.

INDICE

Pāgina

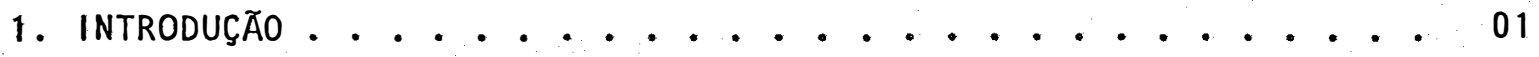

2. REVISÃO dE LITERATURA ....................... 03

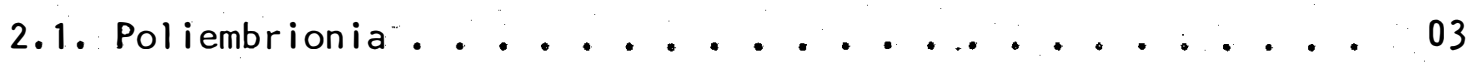

2.2. Embriogênese em tecidos nucelares ........ 06

2.2.1. Embriogênese em nucelos ......... 06

2.2.2. Embriogênese em óvulos ........... 07

2.2.3. Embriogênese em calos nucelares ....... 09

2.2.4. Efeitos do meio de cultura ......... 11

2.2.4.1. Substâncias orgânicas complexas ..... 11

2.2.4.2. Vitaminas ............ 13

2.2.4.3. Reguladores de crescimento ...... 13

2.2.5. Efeitos de subcultivos .......... 15

2.2.6. Efeitos de irradiação . . . . . . 16

2.2.7. Desenvolvimento de embrióides . . . . . . . 18

2.2.8. Variação somaclonal . . . . . . . . 20

2.3. Melhoramento das espécies citricas ........ 22

2.3.1. Métodos convencionais ........... 22

2.3.2. Cultura de.embriões "in vitro" . . . . . . 22

2.3.3. Uso de protoplastos ............ 24

2.3.4. Indução de mutações ........... 25

2.3.4.1. Irradiação de tecidos multicelulares . . 25

2.3.4.2. Irradiação de tecidos nucelares . . . . . -26 
.ii.

Pägina

2.3.4.3. Irradiação de calos nucelares . . . . . 27

2.3.4.4. Agentes mutagênicos em protoplastos . . . 28

2.3.4.5. Agentes mutagênicos em plântulas decapitadas 28

2.3.4.6. Seleção de mutantes ... . . . . 29

2.4. Propagação vegetativa "in vitro" ........ 30

2.4.1. Micropropagação ............ 30 .

2.4.2. Indução de calos em segmentos da planta . . . . 32

2.4.3. Organogênese em calos .......... 33

2.4.4. Enraizamento dos brotos ......... 33

2.5. Cultura de segmentos do fruto . . . . . . . . 34

2.6. Remoção das plantas para o solo . : . . . . . . . 37

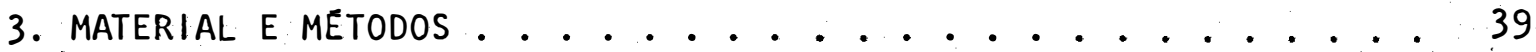

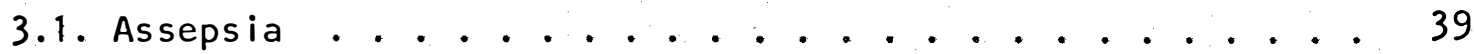

3.2. Meio de cultura ................ 40

3.3. Condições de crescimento ............. 40

3.4. Cultura de nucelos de 'Valência'. ......... 41

3.4.1. Extração do nucelo ........... 41

3.4.2. Diferentes concentrações de auxina/citocinina ... 41

3.4.3. Irradiação de tecido nucelar . . . . . . . 42

3.5. Cultura de óvulos abortivos de 'Pera' ........ 43

3.5.1. Diferentes fases de desenvolvimento ...... 43

3.5.2. Diferentes meios de cultura ......... 43

3.6. Cultura de calos de 'Valência' ........... 44

3.6.1. Desenvolvimento de pseudobulbilhos ...... 44 
iv.

Pāgina

3.6.2. I rradiação de calos globulares (pseudobulbilhos) . . 44

3.7. Individualização de embriōides . . . . . . . 45

3.7.1. Processo seguido para todos os experimentos ... 45

3.7.2. Enraizamento de embriōides de 'Valência' .... . 45

3.8. Propagação clonal de 'Valência' e 'Trifoliata'. . ... . 45

3.8.1. Multiplicação de gemas axilares . . . . . . . 45

3.8.2. Enraizamento de brotos .......... . 46

3.9. Cultura de segmentos do fruto de 'Pera' ........ 47

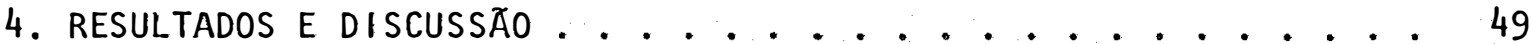

4.1. Cultura de nucelos de 'Valência' em diferentes níveis de au xina e citocinina . . . . . . . . . . . 4 49

4.2. Irradiação do tecido nucelar de 'Valência' . . . . . 57

4.3. Cultura de övulos abortivos em diferentes fases . . . . 68

4.4. Cultura de óvulos abortivos em diferentes meios . . . . 70

4.5. Desenvolvimento de pseudobulbilhos de 'Valência'. . . . 71

4.6. Irradiação de calos globulares de 'Valência' . . . . 73

4.7. Enrạizamento de embriōides de 'Valência' . . . . . . 75

4.8: Cultura de gemas axilares............. . . . 79

4.8.1. Cultivar 'Valência' ........... . . 79

4.8.2. Cultivar 'Trifoliata' ............ 81

4.8.3. Enraizamento de brotos ............ 84

4.9. Cultura de segmentos do fruto de 'Pera' . . . . . . . 86

4.10. Remoção das plantas para o solo........... 88 
.v.

Pägina

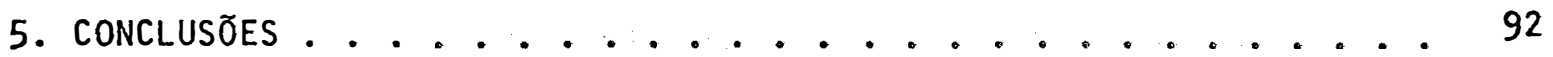

6. LITERATURA CITADA ............................... 95 
.vi.

LISTA DE TABELAS

Tabela

Pāgina

1. Número médio de embrióides obtidos em cultura de nucelos de 'Valência' em diferentes combinações de Cin e 2,4-D expos tos à luz.......................

2 Número médio de embrióides obtidos em cultura de nucelos de 'Valência' em diferentes combinações de Cin e 2,4-D mantidos no escuro . . . . . . . . . . . . . . . .

3 Observações realizadas em nucelos de 'Valência' cultivados em diferentes combinações de Cin e 2,4-D . . . . . .

4 Nümero de embriōides obtidos em cultura de nucelos de 'Va lência' submetidos a diferentes doses de radiação gama na inoculação $(A)$, uma $(B)$, duas $(C)$ e três semanas depois (D)

5 Observações realizadas em cultura de nucelos de 'Valência' submetidos a diferentes doses de radiação gama na inocula ção $(A)$, uma $(B)$, duas $(C)$ e três (D) semanas depois . .

6 Número de embriōides obtidos em cultura de nucelos de 'Va lência' apōs irradiação (em diferentes doses) do meio (E), do nucelo (F) ou do meio e do nucelo (G) . . . . . . .

7 Observações realizadas em cultura de nucelos de 'Valência' apōs irradiação (em diferentes doses) do meio (E), do nuce lo (F) ou do meio e do nucelo (G) ............ 62 
.vii.

Tabela

Pāgina

8 Desenvolvimento de embriōides (\%) individualizados oriundos de nucelos submetidos a diferentes doses de radiação na ino culação (A), uma (B), duas (C) ou três (D) semanas depois.

9 Desenvolvimento de embriōides individualizados obtidos de nucelos apōs irradiação (em diferentes doses) do meio (E), do nucelo (F) ou do nucelo e do meio (G) . . . . . . .

10 Embrióides (NO) e calos (\%) obtidos a partir de cultura de óvulos abortivos de 'Pera' em diferentes fases de desenvol vimento.......................

11 Embriōides (Nọ), plantas e calos (\%) obtidos em cultura de óvulos de 'Pera' em meio "MS"' adicionado de diferentes subs tâncias de crescimento .............. 71

i2 Desenvolvimento de pseudobulbilhos cultivados em meio "MS" adicionado de diferentes substâncias de crescimento . . .

13 Número de embriōides obtidos de calos globulares submetidos a diferentes doses de radiação gama .............

14 Enraizamento de embriōides (\%) oriundos de calos nucelares e de nucelos em diversos hormônios adicionados ao meio "MS"

15 Desenvolvimento do sistema radicular de plântulas de 'Valên cia' (que apresentavam apenas a raiz principal) em meio "MS" adicionado de NAA . . . . . . . . . . . . . . . . 
-ven.

Tabela

Pāgina

16 Nümero médio de brotos em cultura de gemas axilares de 'Va lência' em diferentes combinaçōes de BAP e NAA . . . . .

17 Nümero médio de brotos em cultura de gemas axilares de 'Tri foliata! em diferentes niveis de NAA e BAP . . . . . .

18 Enraizamento de brotos (\%) de 'Valência' e 'Trifoliata' em meio "MS" suplementado por värios reguladores de crescimen

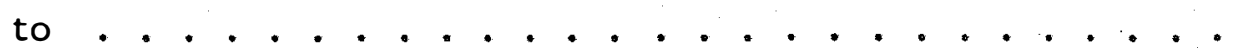

19 Produção de calos (\%) da cv. 'Pera' a partir de albedo è ve sículas em meio "MT" adicionado de diferentes concentrações

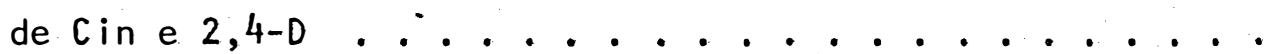

20 Produção de calos (\%) da cv. 'Pera' a partir de albedo e ve siculas em meio "MT" adicionado de diferentes concentrações de Cin e IAA 
.ix.

\section{LISTA DE FIGURAS}

Figura

Pägina

1 Número médio de embriōides por nucelo nos diferentes níveis

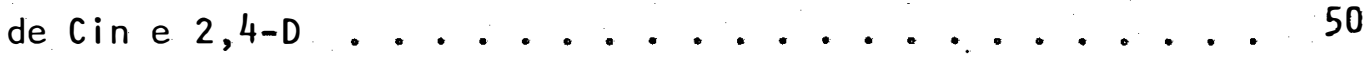

2 Diferenciação de embrióides a partir de nucelos de 'Valên cia' apös 9 semanas de cultivo em diferentes níveis de Cin.

3 Embriōides de 'Valência' diferenciados a partir de nucelos cultivados "in vitro" na ausência de Cin e 2,4-D .....

4 Produção de calos (\%) a partir de nucelos de 'Valência' cul tivados em diferentes niveis de Cin e 2,4-D ( $A-0,0 ; B-0,5$; $\mathrm{C}-1,0$ e $\mathrm{D}-2,0 \mathrm{mg} / 1) \ldots . . . . . . . . . . . .56$

5 Número de embrióides obtidos em cultura de nucelos submeti dos a diferentes doses de radiação gama e em diferentes fa ses......................

6 Número de embriōides obtidos de nucelos após irradiação (em diferentes fases) do meio (E), do nucelo (F) ou do nucelo e do meio $(G)$. . . . . . . . . . . . . . .

7 Nucelos que produziram calos (\%) após irradiação (em dife rentes doses) do meio (E), do nucelo (F) ou do meio e do nu $\operatorname{celo}(G)$. . . . . . . . . . . . .

8. Calos globulares obtidos de nucelos de 'Valência' cultiva dos em meio irradiado, mostrando elevado potencial embriogê nico .......................... 
9 Calos de 'Pera' oriundos de óvulos abortivos evidenciando a

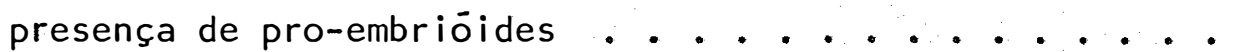

10 Número de embriōides obtidos de calos globulares submetidos a diferentes doses de radiação gama . . . . . . . 75

11 Embriōides de 'Valência' obtidos de nucelos após nove sema nas de cultura em meio bāsico "MS". . . . . . . . 76

12 Desenvolvimento da plântula a partir de embriōides de 'Va lência' obtidos de cultura de nucelos e individualizados em meio bāsico "MS" . . . . . . . . . . . . . . .

13 Número médio de brotos com mais de $1 \mathrm{~cm}$, obtidos em cultura de gemas axilares de 'Valência' em diferentes combinações de NAA e BAP .....................

14 Multiplicação de 'Valência' a partir de gemas axilares cul tivadas em NAA-0,2 mg/l e vārias concentrações de BAP . .

15 Número médio de brotos com mais de $1 \mathrm{~cm}$ obtidos em cultura de gemas axilares de 'Trifoliata' em diferentes combinações

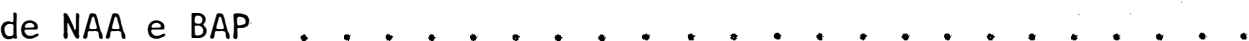

16 Enraizamento de brotos de 'Trifoliata' em meio "MS" adicio

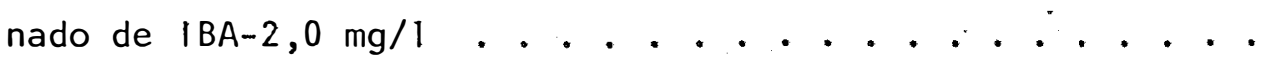

17 Plântulas de 'Valência' obtidas de cultura de nucelos, pron tas para serem removidas dos tubos de ensaio para o solo. 
.xi.

Figura

Pägina

18 Plântula de 'Valência' obtida de cultura de nucelos, com aproximadamente 1 ano após a remoção dos tubos de ensaio 


\section{ABREVIAÇÕES}

A caracterização do meio de cultura e as diversas substân cias que compõe o meio são referidas no decorrer do trabalho atravēs de abreviaturas cujo significado è dado a seguir:

$$
\begin{aligned}
& \text { "MS" = MURASHIGE e SKOOG (1962) } \\
& \text { "MT" = MURASHIGE e TUCKER (1969) } \\
& E M=\text { extrato de malte } \\
& E L=\text { extrato de levedura } \\
& \mathrm{CH}=\text { caseina hidrolizada } \\
& A C=\text { àgua de côco } \\
& \text { Cin = cinetina } \\
& 2 \mathbf{i} \mathbf{p}=2-\mathbf{i} \text { sopenten } \mathbf{i} \text { laden } i n a \\
& A A=\text { àcido ascörbicio } \\
& A D=\text { adenina } \\
& \text { ADS = sulfato de adenina } \\
& A C \mathbf{i}=\text { ácido cítrico } \\
& \mathrm{GA}_{3}=\text { àcido giberēlico } \\
& I A A=\text { àcido indolacét ico }
\end{aligned}
$$

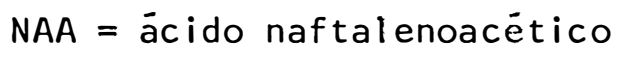

$$
\begin{aligned}
& I B A=\text { àcido indolbutírico } \\
& B A P=\text { benzil aminopurina } \\
& \text { 2, 4-D = ácido 2,4-diclorofenoxi-acét ico } \\
& \text { 5-HNB = 2-hidroxi-5-nitro benzilbromida } \\
& A G=8 \text {-aza-guanina } \\
& \text { CCC }=2 \text {-cloro-et ilmet } \mathrm{i} \text { lamonia } \\
& \text { alar = ácido 2,2-metilhidrazida }
\end{aligned}
$$


.xiii.

\section{"CURRICULUM UITAE" .}

MOACIR PASQUAL, nascido a 25 de janeiro de 1949 em Videira -SC., recebeu o título de Engenheiro Agrônomo em dezembro de 1971 pela Es cola de Agronomia "Eliseu Maciel", da Universidade Federal de Pelotas - Pe lotas-RS. e, de Mestre em Agronomia, àrea de Concentração Fitotecnia, em dezembro de 1976, pela Escola Superior de Agricultura de Lavras - Lavras MG

Desde janeiro de 1972 , exerceu suas atividades profissionais em pesquisa com Fruticultura de Clima Temperado, junto às Estações Experi mentais de Videira e Caçador-SC.; inicialmente pelo extinto Instituto de Pesquisa e Experimentação Agropecuärias do Sul (IPEAS)-Departamento Nacio nal de Pesquisa e Experimentação Agropecuärias (DNPEA), a partir de jane ro de 1974 pela Empresa Brasileira de Pesquisa Agropecuäria (EMBRAPA), e, de junho de 1978 a março de 1985 pela Empresa Catarinense de Pesquisa Agro pecuäria (EMPASC). Durante este período foi autor de 40 trabalhos cientificos publicados, na maioria contemplando aspectos que envolvem o melhora mento das fruteiras de clima temperado e, a polinização e quebra de dormên cia da macieira (Malus domestica Borkh.).

Atualmente, pela Seção de Radiogenética do Centro de Energia Nuclear na Agricultura (CENA), órgão da Universidade de São Paulo (USP), de senvolve trabalhos de pesquisa com melhoramento de plantas através da indu ção de mutações e fazendo uso das técnicas de cultura de tecidos e células. 
.xiv.

\section{REGENERAÇAO DE PLANTAS "IN VITRO" E RADIOS.SENSITIVIDADE DE TECIDOS NUCELARES DE CITROS}

Autor: MOACIR PASQUAL

Orientador: Prof. Dr. Akihiko Ando

\section{RESUMO}

Existem diversas limitações, como apomixia, esterilidade ga mética e incompatibilidade, ao melhoramento das espécies cítricas, razão da maioria das cultivares ter se originado por mutações espontâneas.

- Procurou-se através deste trabalho, determinar uma metodolo gia para regeneração de plantas a partir de nucelos, calos nucelares e ge mas axilares, bem como, para induzir mutantes com o uso de radiação gama, de forma a explorar os benefícics oferecidos pelas técnicas de cultura de tecidos e células.

Nucelos da cv. 'Valência' e óvulos abortivos da cv. 'Pera' foram cultivados "in vitro" em meio "MS" adicionado de värias substâncias reguladoras do crescimento. Tanto nucelos extraídos de frutos de 'Valên cia' com aproximadamente' 12 semanas apōs a polinização, como calos oriundos destes mesmos nucelos, foram submetidos a diferentes doses de radiação ga ma ecultivados "in vitro". Gemas axilares de 'Valência' e 'Trifoliata' foram cultivadas em meio "MS" suplementadocomdiversas combinações de uma auxina e uma citocinina. 
Houve diferenciação de embriōides tanto diretamente do nuce lo como via formação de calos em 'Valência' e 'Pera' e ótima multiplicação de gemas axilares em 'Valência' e 'Trifoliata'.

A adição de auxinas e citocininas inibe a embriogênese em nucelos. 0 aumento das doses de radiação gama sobre nucelos e calos nuce lares provoca uma redução do nümero de embriōides, mais acentuada se apli cadas em fases posteriores a inoculação. Pode-se definir uma dose de 1,0a 2,0 kR para tratamento de nucelos em trabalhos de indução de mutações. A irradiação apenas do meio de cultura aumeṇta a proliferação de calos. No ta-se um elevado indice de anormalidade nos embrióides principalmente com doses mais elevadas de raios gama.

0 enraizamento de embriōides é melhor estimulado por. $\mathrm{GA}_{3}$ $-1,0$ ou $\mathrm{NAA}-0,1 \mathrm{mg} / \mathrm{l}$.

Para a cv. 'Valência', a multiplicação de gemas foi mais es timulada por NAA-0,2 + BAP-0,2 mg/l e o enraizamento de brotos por NAA-0,1 a $1,0+\mid B A-2,0 \mathrm{mg} / 1$, enquanto que, para 'Trifoliata' o melhor índice de multiplicação de gemas se deu com NAA-1,0 + BAP-1,0 mg/l e de enraizamento de brotos com IBA-1,0 a $2,0 \mathrm{mg} / 1$ ou $N A A-5,0+B A P-0,1 \mathrm{mg} / 1$ ou ainda NAA-1,0 $+1 B A-2,0 \mathrm{mg} / 1$. 
.xui.

\section{"IN VITRO" REGENERATION OF PLANTS AND RADIOSENSITIVITY OF NUCELLAR TISSUES IN CITRUS}

Author: MOACIR PASQUAL

Adviser: Prof. Dr. Akihiko Ando

\section{SUMMARY}

There are various limiting factors, such as apomixis, gametic sterility and incompatibility in the breeding of Citrus species. In view of this, the majority of Citrus cultivars have originated from spontaneous mutation.

In the present work, attempts were made to determine a methodology to regenerate plants from nucelli, nucellar callus and axillary buds, and also to induce mutants by gamma radiation in order to explore the benefits offered by the technology of tissue and cell culture.

Nucelli of the cultivar 'Valencia' and abortive ovules of the cultivar 'Pera' were" cultured "in vitro" on the "MS"' medium, supplement ed with various growth regulators. Both nucelli, extracted from the fruits of 'Valencia' approximately 12 weeks after pollination, and callus originat ed from these nucelli, were irradiated with different doses of gamma-rays and cultured "in vitro". Axillary buds of 'Valencia' and 'Trifoliata' were cultured on the "MS" medium supplemented with various combinations of one auxin and one cytokinin. 
-xvii.

Differentiation of embryoids was observed directly from nucelli as well as from nucellar callus in 'Valencia' and 'Pera', and excellent multiplication of axillary buds of 'Valencia' and 'Trifoliata' was also observed.

Addition of auxin and cytokinin inhibits the embryogenesis of nucelli. Increase of gamma-radiation dose on nucelli and nucellar "callus caused a reduction in number of embryoids formed, and this was more noticeable when gamma-radiation was applied in posterior periods after inoculation. It has been concluded that gamma-ray doses of 1.0 to $2.0 \mathrm{kR}$ are adequate to the treatment of nucelli in mutation breeding. High frequency of abnormality of embryoids was observed with higher doses of gamma-ray.

The rooting of embryoids was stimulated with the addition of $\mathrm{GA}_{3}-1.0$ or $\mathrm{NAA}-0.1 \mathrm{mg} / 1$.

For the cultivar 'Valencia', multiplication of buds was stimulated with the addition of $N A A-0.2+B A P-0.2 \mathrm{mg} / 1$, and the rooting of shoots with the addition of NAA-0.1 to $0.2+1 B A-2.0 \mathrm{mg} / 1$, while for 'Trifoliata' the highest frequency of bud multiplication occurred with $N A A-1.0+B A P-1.0 \mathrm{mg} / 1$ and of rooting of shoots with $1 B A-1.0$ to $2.0 \mathrm{mg} / 1$ or $\mathrm{NAA}-5.0+B A P-0.1 \mathrm{mg} / 1$ of $\mathrm{NAA}-1.0+1 \mathrm{BA}-2.0 \mathrm{mg} / \mathrm{l}$. 


\section{INTRODUCATO}

A citricultura desempenha um papel de extrema importância, considerando que o Brasil é o segundo maior produtor de frutos citricos do mundo e o primeiro exportador mundial de suco de laranja, assumindo lugar de destaque na pauta brasileira de exportações.

0 melhoramento das espécies citricas pelos métodos conven cionais muito pouco tem contribuido, pois, é seriamente limitado pela ocor rência de poliembrionia, esterilidade masculina, incompatibilidade e longo período de juvenilidade dos "seedlings".

A maioria das cultivares tem sido obtida a partir de muta ções espontâneas, o que demonstra um potencial de resposta destas espécies a tratamentos com agentes mutagênicos. Bons resultados tem sido obtidos através da indução de mutações em tecidos multicelulares como gemas e se mentes, conduzindo porém à formação de quimeras.

Com o desenvolvimento das técnicas de cultura de tecidos e células e a possibilidade da diferenciação de embrióides a partir de célú las individuais do nucelo, de calos nucelares emesmo de "seedlings" decapi 
tados, a aplicação de agentes mutagênicos sobre a célula inicial responsā vel por esta diferenciação se constitui numa alternativa muito promissora.

Estudos de fenômenos morfológicos, citológicos e fisiológi cos podem ser conduzidos "in vitro" sobre calos obtidos de qualquer parte da planta e inclusive de segmentos do fruto.

A propagação rápida de clones ou mutantes com características superiores, ațravés da cultura de gemas axilares se constitui numa das grandes aplicações da cultura de tecidos. Esta forma de clonagem garante um fornecimento abundante de ápices meristemáticos para a microenxertia, técnica largamente utilizada na obtenção de plantas citricas isentas de vi roses.

objetivou-se com o presente trabalho: 1) o desenvolvimento das técnicas de regeneração de plantas "in vitro" a partir de nucelos e óvu los, associadas à indução de mutações através do uso de raios gama; 2) mul tiplicação das plantas de 'Valência' (Citrus sinensis) e 'Trifoli ata' (Poncirus trifoliata) obtidas "in vitro" por meio de cultura de gemas axi lares; 3) obtenção de calos a partir de segmentos do fruto; 4) criar a opor tunidade para um contacto e familiarização com as técnicas de cultura de tecidos e células, para posterior uso em programas de melhoramento princí palmente com espécies de propagação vegetativa e de longo período juvenil. 


\section{REVISATO DE LITERATURA}

São abordados vārios aspectos relacionados com a diferencia ção de embriões nucelaṛes (embriōides) "in vitro" e "in vivo" e seu uso no melhoramento, principalmente através da indução de mutações. Considerações sobre a micropropagação a partir de āpices caulinares e gemas axilares, e a indução de calos de diversos explantes inclusive de segmentos do fruto, também farão parte desta revisão.

\subsection{Poliembrionia}

Muitas espécies e cultivares dos gêneros Céticus (incluindo Poncirus e Fortunela), Mangíera e Syzygium, possuem a caracteristica de reproduzir-se agamicamente por apomixia do tipo agamospermia apospörica ou poliembrionia (MOREIRA et alii, 1947; FROST e SOOST, 1968; RANGAN et alii, 1969) formando vārios embriōides a partir da diferenciação de células indi viduais do nucelo. Os embrióides normalmente se originam e se desenvolvem na extremidade micropilar do nucelo (MAHESHWARI e RANGASWAMY, 1958) projé tando-se para dentro do saco embrionärio, juntamente com o embrião (origem sexuada). 
A extensão da poliembrionia é influenciada pela cultivar, es tado nutritivo do fruto, fatores ambientais e cultivar polinizadora (EROST e SOOST, 1968). Tem sido encontrados de 1 a 40 embrióides por nucelo (OHTA e FURUSATO, 1957). Uma espécie de limão foi autopolinizada e produzilu qua se exclusivamente plântulas nucelares; $46 \%$ das plântulas foram zigóticas quando polinizada por Poncirus trifoliata (CAMERON e SOOST, 1969).

A época de iniciação e desenvolvimento dos embrióides tem ainda sido questionada. Há citações de que a iniciação "in vivo" coincide com a primeira.divisão do zigoto (BACCHI, 1943), porém, em sementes de 'Pon kan' excisadas 47 dias após a polinização, foram encontrados embrióides no estágio unicelulado, independentemente da presença do zigoto (ESEN e SCOST, 1977). SINGH (1.63) encontrou embriōides globulares em óvulos de C. reti culata cv. 'Nagpuri' com 55 dias, a contar da polinização, enquanto que não houve evidência da iniciação destes embrióides em C. aurantium L., 100 a 120 dias após a polinização, quando o zigoto estava no estăgio globular ou cordiforme (RANGAN et alii, 1969).

Polinização e fertilização foram consideradas um pré-requisi to essencial para a embriogênese nucelar de citros. (MAHESHWARI e RANGASWA MY, 1958; FROST' e SOOST, 1968; BUTTON e BORNMAN, 1971), apesar de ter sido registrada a fornação de sementes em $C$. sinensis 0sb. e C. paradisi Macf. e, de embrióides "in vitro" (BUTTON e BORNMAN, 1971; KOCHBA et alii, 1972) sem polinização. Hä evidências de que com certos híbridos interespecifí cos a polinização é definitivamente requerida (FROST e SOOST, 1968), ao pas so que, algo menos claro é a necessidade da fertilização. A fertilização da célula-ôvo deve ocorrer em 3 dias à 4 semanas após a polinização e, a 
divisão do zigoto inicia-se logo a seguir. (SPIEGEL-ROY e KOCHBA, 1980).

Poliembrionia em citros é um carater recessivo e controlado por uma série de genes múltiplos (MAHESHWARI e RANGASWAMY, 1958), os quais podem regular a sintese de um potente inibidor da embriogênese (ESAN, 1973) em células nucelares de variedades monoembriônicas.

Teoricamente todas as plântulas nucelares seriam considera das geneticamente idênticas à planta mãe (FROST e SOOST, 1968). No entan to, variabilidade fenotipica tem sido verificada tanto entre plantas de uma mesma cultivar como entre alguns padrọes enzimáticos de plântulas deriva das de uma mesma semente (IGLESIAS et alii, 1974). Esta variabilidade tem sido atribuida à expressão da juvenilidade, pol inização e fertilização e, à natureza quimérica de certas cultivares de citros (PARLEVLIET e CAMERON, 1959; BITTERS et alii, 1970).

Existe em citros um elevado grau de heterozigose devido a po. linização cruzada, facilidade de mutações expontâneas e prevalecimento da poliembrionia. Genes recessivos são acumulados, tendo a poliembrionia um importante papel na diferenciação evolucionária (CAMERON e FROST, 1968).

Linhagens nucelares de citros são livres de virus, mais vigo rosas e usualmente de mais alta produção, e tem maior longevidade do que as árvores que the deram origem, embora em sua constituição genética sejam idênticas (BUTTON e BORNMAN, 1971).

0 uso de nucelos como uma fonte de material livre de virus teve sua importância reduzida, devido aos métodos mais recentemente desen 
volvidos de termoterapia e microenxertia "in vitro" (MURASHIGE et alii, 1972; NAVARRO et alii, 1975), que tem permitido a obtenção de plântulas isentas de viroses e sem as características de juvenilidade.

\subsection{Embriogênese em tecidos nucelares}

\subsubsection{Embriogênese em nucelos}

Considerando a tendência natural do nucelo formar embriōi des, a maioria da embriogênese artificialmente induzida em citros se dá nes te tecido.

As primeiras tentativas para induzir a formação de embriões nucelares "in vitro" foram feitas por RANGASWAMY (1958, 1959, 1961). Foram obtidos embriōides de variedades poliembriônicas, porém, na época da extra ção jā haviam prōembriōides formados "in vivo".

RANGAN et alii (1968, 1969) e BITTERS et alii (1970) foram os primeiros a induzir embriogênese adventícia diretamente em tecidos nuce lares excisados de sementes em desenvolvimento de cultivares monoembriônicas. Eles obtiveram embriōides "in vitro" de diversas variedades (100 a 120 dias após a polinização), com o objetivo de produzir plantas livres de viroses. Embrióides desenvolveram em um máximo de $20 \%$ dos explantes nuce lares e originaram plantas.

Usualmente apenas 10 a $30 \%$ dos nucelos produz embrióides (JUAREZ et alii, 1976), embora tenha-se registrado pröximo à $100 \%$ de suces so com citron 'Ethrog' e limão 'Ponderosa' (ESAN, 1973). Este bom resulta 
do foi obtido em nucelos com a extremidade chalazal embebida no meio, en quanto que em outras posições foram formados poucos embriōides e calos de sorganizados.

A técnica da cultura de nucelos "in vitro" tem sido usada com sucesso para induzir embriōides em uma série de cultivares monoembriô nicas de muitas espécies cítricas (RANGAN et.alii, 1968, 1969; BITTERS et alii, 1970; DEIDDA, 1973; ESAN, 1973; JUAREZ et alii, 1976). A formação de embriōides é observada apōs 3-6 semanas de cultura na extremidade micro pilar do nucelo. . São produzidos de 1 à 12 embrióides por explante e sua proliferação frequentemente ocorre por gemação.

Uma temperatura constante de $27^{\circ} \mathrm{C}$ e 16 horas diärias de luz a 1000 lux são adequadas para embriogênese nucelar (ESAN, 1973). Meio só lido foi superior ao meio líquido estacionārio ou em agi tação.

\subsubsection{Embriogênese em ōvulos}

A cultura de óvulos fertilizados, não fertilizados ou abor tivos se constitui em outra alternativa para a obtenção de plāntulas nuce lares "in vitro", principalmente em cultivares que não produzem sementes. óvulos podem ser excisados de ovārios de flores e frutos em desenvolvimento.

Óvulos fertilizados foram cultivados primeiramente por MAHE SHWARI e RANGASWAMY (1958) e RANGAN et alii (is69).

Embriogênese "in vitro" tem sido obtida a partir de óvulos não fertilizados ou abortivos com diversas cultivares desde a época da po 


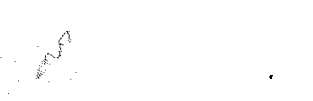

$-$

.08 .

I inização (BITTERS et alii, 1970; NAVARRO et alii, 1979; TUSA et alii, 1983), algumas semanas após a ântese e, atē 3 a 5 meses mais tarde (BUTTON e BORN MAN, 1971; KOCHBA et alii, 1972; DEIDDA, 1973; ESAN, 1973; JUAREZ et alii, 1976). Tndices ótimos tem sido registrados em óvulios 6 semanas após a po linização para a cultivar 'Robertson'e 10 a 12 semanas para 'Temple' (BIT TERS et alii, 1970), 6 a 8 semanas para 'Valência' e 'Marsh' com 44 e $68 \%$ de sucesso respectivamente (KOCHBA et alii, 1972) e 2 a 10 semanas com 68$80 \%$ de sucesso (NAVARRO et alii, 1979) em diversas cultivares.

Em alguns casos evidenciou-se a presença do zigoto, como exemplo em frutos de 100 a 120 dias (DEIDDA, 1973) e 13 a 15 semanas (JUA REZ et a $i$ ii, 1976), o qual foi el iminado.

Os primeiros sinais de crescimento foram observados apōs 2 semanas através de uma excrescência na região da micrópila e em 4 a 5 sema nas alguns embriōides eram perfeitamente distinguíveis, cujo crescimento continuou até 8ạ a 10ạ semana (DEIDDA, 1973; JUAREZ et alii, ̈976; NAVARRO et alii, 1979). A evolução do óvulo "in vitro" normalmente é mais lenta que a do nucelo, obtendo-se embrióides até 15 semanas em cultura, sem quál quer crescimento prévio (NAVARRO et alii, 1979).

Frutos podem ser armazenados sob refrigeração $\left(4^{\circ} \mathrm{C}\right)$ atē 4 semanas sem afetar o potencial de sobrevivência e embriogênese do nucelo (ESAN, 1973; NAVARRO et alii, 1979).

A técnica da cultura de óvulos não fertilizados foi utiliza da por STARRANTINO e RUSSO (1983) para introduzir as cultivares 'Newhal', 'Robertson' e.'Gillets' da California para a ltalia. Os óvulos foram remo 
vidos em condições assépticas e remetidos em frascos de vidro com gase.

O uso de óvulos inteiros é mais gratificante devido à sua facilidade de extração, quando comparada à tediosa extração do nucelo.

\subsubsection{Embriogênese em calos nucelares}

Muitos autores tem reportado o súrgimento esporádico de pe. quenos calos em cultura de nucelos e óvulos, além dos embriōides diferen ciados diretamente (MAHESHWARI e RANGASWAMY, 1958; RANGASWAMY, 1958, 1961; SABHARWAL, 1963; BUTTON e BORNMAN, 1971; MITRA e CHATURVEDI, 1972; KOCHBA et alii, 1972; DEIDDA, 1973).

Na primeira tentativa de cultura de óvulos com sucesso (RAN GASWAMY, 1958) foi obtida uma massa de pseudobulbi ihos, termo empregado pe la primeira vez por LA RUE (1954), citado por RANGASWAMY (1958), para de signar as curiosas bolas de tecidos obtidas em cultura de gametófitos femi ninos de Zamia. Estes calos de citros compreendem nódulos compactos a es féricos de 0,1 a 1,0 mm de diâmetro, que variam de côr branca a creme, e que unidos entre si, dão ao calo uma estrutura porosa e friável.

Estudos de anatomia e desenvolvimento (BUTTON et alii, 1974), e aspectos fisiológicos (KOCHBA e SPIEGEL-ROY, 1973; KOCHBA e BUTTON, 1974) nestes tecidos, evidenciaram que praticamente qualquer célula é naturalmen te. embriogênica e, que os embriōides se originam de células individuais. Estes pseudobulbilhos quando em condições adequadas podem evoluir formando proembriōides e posteriormente plânitulas (BUTTON et alii, 1974). Frequen temente há uma proliferação a partir de células superficiais ou do inte 
rior dos proembriōides.

A presença de corpúsculos globulares precedida pela forma ção de calos tem sido observada 3-4 semanas após a inoculação dos nucelos (BUTTON e BORNMAN, 1971; KOCHBA e SPIEGEL-ROY, 1976a; JUAREZ et alii, 1976; STARRANTINO et alii, 1978), a partir da região micropilar. Maior quantida de de embrióides foi obtida de óvulos com 40-60 dias após a ântese (TUSA et alii, 1983).

Estudos em microscopia eletrônica de calos de 'Shamouti' (BUT TON et alii, 1974) mostraram que estes tecidos compreendem pequenos proem briōides globulares ou meristemóides (TORREY, 1966) em vários estágios de desenvolvimento e são desprovidos de tecido parenquimatoso desorganizado. Foram definidos em um dado tempo (KOCHBA et aliii, 1974) embriōides em 4 es tágios a saber: 1) globulares $(1 \mathrm{~mm}) ; 11$ ) alongados $(2-3 \mathrm{~mm}) ; 111)$ cordifor mes (3-5 mm, com cotiledones e primördios de raiz); IV) com cotiledones bem desenvolvidos.

Culturas de óvulos não desenvolvidos extraídos de frutos ma duros de algumas cultivares de citros foram efetuadas por SIARRANTINO e RUS SO (1980). Na ocasião, embriōides estavam presentes e a partir deles houve proliferação com produção de calos friáveis e embriogênicos. Embriōides fo ram obtidos de calos oriundos da parede do ovário não polinizado de duas espécies poliembriónicas (MITRA e CHATURVEDI, 1972) e de pedaços de óvulo não fertilizado de C. aurantifolia.

Observou-se diferenciação de pseudobulbilhos, proembriōides e regeneração completa de planta à partir de células isoladas de calos for 
mados em meio "MT", por maceração em agitador na presença das enzimas "ma cerase" e "macerozyme" - 3 a 4\% (BUTTON e BOTHA, 1975).

Desde que é difícil excisar proembriōides jovens, métodos que permitem uma cultura com creșcimento contínuo de pseudobulbilhos adqui rem especial interesse, fornecendo uma fonte especial de embriōides em qual quer época do ano. Devido à capacidade de reproduzirem o genōtipo e tam bém por serem livres de virus, estes tecidos são de imenso valor aos melho ristas de citros. Hä a possibilidade do isolamento de células a partir des tas massas de tecido reprodutivo, as quais são consideradas semelhantes a ovos fertilizados para propósitos de morfogênese (RANGASWAMY, 1961).

\subsubsection{Efeitos do meio de cultura}

0 meio normalmente utilizado na cultura de tecidos nucelares é o "MS" (MURASHIGE e SKOOG, 1962), com algumas modificas.ões, principalmen te as propostas por MURASHIGE e TUCKER (1969) - meio "MT".

\subsubsection{Substâncias orgānicas complexas \\ 0 extrato de malte (EM) $-500 \mathrm{mg} / 1$ foi adicionado em värias} "culturas promovendo embriogênese em nucelos e calos nucelares e prolifera ção de calos (RANGAN et alii, 1968, 1969; BITTERS et alii, 1970; BUTTON e BORNMAN, 1971; KOCHBA et alii, 1972; NAVARRO et alii, 1979) de muitas cul tivares de citros, apesar de em alguns casos não ter mostrado efeitos posi tivos (RANGASWAMY, 1959; ESAN, 1973). Observou-se que os calos nucelares rapidamente perdem a dependência do EM para a embriogênese. 
A formação de pseudobulbilhos foi estimulada por EM adicio nado de $A D-25$ a $40 \mathrm{mg} / 1$ (BUTTON e BORNMAN, 1971; KOCHBA e SPIEGEL-ROY, 1973; STARRANTINO et alii, 1978), produzindo embriōides em atē 37\% das cul turas. 0 EM, quanto aos seus efeitos sobre a embriogênese, pode ser subs tituido por AD (BUTTON e BORNMAN, 1971; KOCHBA e SPIEGEL-ROY, 1973), por ADS + Cin (MITRA e CHATIRVEDI, 1972), ou por ADS + NAA + suco de laranja (RANGAN et alii, 1968, 1969; DEIDDA, 1973). A fração ativa do EM não è bem conhecida, mas, provavelmente, são incluídos um ou mais aminoácidos è possivelmente uma citocinina (VAN STADEN, 1974, citado por RANGAN et alii, 1969).

o suco de laranja não mostrou efeito sobre a embriogênese nucelar (ESAN, 1973), embora', pareça estimular o crescimento de calos de citros em alguns casos (MURASHIGE e TUCKER, 1969; THORPE et alii, 1971; ER NER et alii, 1975) e não em outros (BRUNET e IBRAHIM, 1973). A principal ação ativa, pelo menos com respeito ao crescimento de calos, parece ser o äcido cítrico (ERNER et alii, 1975).

0 extrato de levedura apesar de não ter efeito sobre a em briogênese nucelar (ESAN, 1973) aumentou o desenvolvimento de örgãos em cul turas de nucelos (RANGASWAMY, 1961; SINGH, 1963).

A caseina hidrolizada - $400 \mathrm{mg} / 1$, separadamente ou em combi nação com extrato de levedura ou cinetina - $2 \mathrm{mg} / 1$, promoveu a formação de pseudobulbithos e embriōides (RANGASWAMY, 1958, 1961; SABHARWAL, 1963) e iniciação de calos, porém, às vezes não mostrou efeito algum (ESAN, 1973).

A água de côco tem sido amplamente usada em cultura de tec 
dos (STEWARD et alii, 1970). Seu efeito benéfico foi demonstrado sobre a embriogênese em culturas nucelares (BUTTON e BORNMAN, 1971; KOCHBA et alii, 1972; MITRA e CHATURVEDI, 1972) e de células de citros (BUTTON e BOTHA, 1975) e, sobre o desenvolvimento normal de embrióides globulares (SABHAR $W A L, 1963)$, apesar de ter sido observado um efeito detrimental sobre ocres cimento de embriōides originários de pseudobulbilhos (RANGASWAMY, 1961).

\subsubsection{Vitaminas}

Ótimos niveis de algumas vitaminas para proliferação de te cidos de citros foram estabelecidos por MURASHIGE e TUCKER (1969). ESAN (1973) evidenciou como essencial apenas a tiamina $\mathrm{HCl}-10 \mathrm{mg} / \mathrm{l}$ e formação de pseudobulbilhos diretamente do tecido nucelar de $C$. sinensis $c v$. Washing ton Navel' foi estimulada por ácido ascórbico (BUTTON e BORNMAN, 1971).

\subsubsection{Reguladores de crescimento}

Auxinas e citocininas são claramente os compostos de maior significância na cultura de tecidos de plantas. SKOOG e MILLER (1957) mos traram que com um adequado balanço nos niveis destes dois fatores poder-se - ia estabelecer um controle sobre o crescimento e diferenciação das cultú ras "in vitro". Normalmente uma al ta concentração de auxina e baixa de ci tocinina promovem o desenvolvimento de raiz e abundante proliferação de cế lulas com formação de calos, enquanto que, baixa concentração de auxina e alta de citocinina resulta na multiplicação dẹ gemas.

o hábito de crescimento autônomo de calos indica um adequa do nivel endögeno de auxinas e possivelmente também de outras substâncias 
.14 .

de crescimento. A manipulação deste nível de auxina pode levar ao estímu lo ou supressão da embriogênese.

A adição das auxinas IAA, NAA e 2,4-D ao meio de cultura, su primiu significativamente ou completamente a embriogênese nucelar (ESAN, 1973), enquanto inibidores da síntese de auxinas como 7-azi-indol e 5-HNB, estimularam fortemente este processo (KOCHBA e SPIEGEL-ROY, 1977 b).

Citocininas aparentemente não essenciais (MURASHI GE e TUCKER, 1969; KOCHBA et alii, 1972; GRIMBLAT, 1972) aumen tam a proliferação de pseudobulbi lhos (RANGASWAMY, 1958). Is.to tem sido observado com a adição de $A D-25$ a $80 \mathrm{mg} / 1$ (KOCHBA $e$ SPIEGEL-ROY, 1976a; STARRANTINO et alii, 1978) e BAP - 5 a 25 mg/l. Da descendência de um só nucelo em meio com EM-500+BAP $-20 \mathrm{mg} / 1$ foram obtidas até 200 plântulas (STARRANTINO et aliii, 1978).

Embriogênese em nucelo foi suprinida após aplicação de Cin, ADS e timidina (ESAN, 1973). Na presença de C.in a inibição aumentou com a concentração e, $A G$ claramente estimulou a embriogênese, mesmo em concentra ção muito baixas - 0,001 mg/l (KOCHBA e SPIEGEL-ROY, 1977b). Embora AG tenha sido reportada possuir efeitos antagônicos sobre a atividade da citoci nina, ela è também conhecida como um mutagênico e provavelmente tem outros metabölicos (LESCURE, 1973).

Auxinas e citocininas quando usadas juntas podem estimular a embriogênese (KOCHBA et alii, 1972; MITRA e CHATURVEDI, 1972). Merrhores 
calos nucelares foram crescidos em cinetina $-0,01 \mathrm{mg} / 1+1 \mathrm{AA}-1,0 \mathrm{mg} / \mathrm{l}$, ou apenas cinetina-1,0 mg/1 (KOCHBA e SPIEGEL-ROY, 1973).

A embriogênese não parece ser estimulada pelo $\operatorname{GA}_{3}$ (MITRA $e$ CHATURVEDI, 1972; ESAN, 1973), e sim, foi fortemente suprimida quando apli cado de 1 a $30 \mathrm{mg} / 1$. O efeito inibidor do $\mathrm{GA}_{3}$ foi confirmado com o uso de dois inibidores da biossintese do $\mathrm{GA}_{3}$ ( $C C C$ e alar), que em concentrações su periores a $10 \mathrm{mg} / \mathrm{l}$ estimularam significativamente a embriogênese.

0 surgimento de calos com subsequente organização em embri öides foi influericiado por $\mathrm{GA}_{3}$, os quais posteriormente se tornaram habi tuados (KOCHBA et alii, 1972). A evolução de pseudobulbilhos em embriōi deś foi estimulada por $G_{3}$ nas várias doses testadas $(10-100 \mathrm{mg} / 1)$, sendo que com $50 \mathrm{mg} / 1$ observou-se a formação de novos embrióides a partir da su perfície de pseudobulbilhos esféricos.

\subsubsection{Efeitos de subcultivos}

Uma vez estabelecidos os calos podem ser mantidos indefini damente bem como seu potencial embriogênico; desde que sejam subcultivados em tempos adequados, uma vez que o intervalo entre passagens pode afetar o grau de desenvolvimento dẹ embrióides.

De modo geral, após um determinado número de subcultivos os calos se tornam habituados no que diz respeito às suas necessidades de au xinas e citocininas, fenômeno regular em cultura de tecidos nucelares de citros, sem perder a capacidade de produzir embrióides. 
Calos foram subcultivados a cada 4-5 semanas e apös 8 passa gens algumas linhagens se tornaram habituadas (KOCHBA e BUTTON, 1974), di ferenciando embrióides em 20-30\% das culturas, com aproximadamente 1,5 em briōides por cultura. Observou-se uma diferenciaçã் de embriōides 10 vezes maior com o envelhecimento dos calos por 6 semanas e 100 vezes por 14 sema nas, quando comparados à subcultivos realizados a cada 3 semanas; isto foi atribuido a um decréscimo no teor de auxina com o envelhecimento (GALSTON e DAVIES, 1969). Calos envelhecidos por 20 semanas perderam o potencial embriogênico.

Maior produção de embriōides foi obtida com subcultivos a cada 9 semanas em relação a 6 semanas, onde houve também produção de embrí óides e pseudobulbilhos, e 3’semanas, sem formação de embriōides, porém, com a mäxima proliferação de células. Após vários subcultivos de 3 semanas houve necessidade de $3-4$ passagens a cada 6 semanas para que os calos recu perassem seu potencial embriogênico (BUTYON e RIJKENBERG, 1977).

\subsubsection{Efeitos de irradiacão}

Calos nucelares foram submetidos à irradiação gama $\quad\left(\begin{array}{lll}0 & \text { a } 32\end{array}\right.$ kR) com uma intensidade de $3,1 \mathrm{kR} / \mathrm{h}$ (SPIEGEL-ROY e KOCHBA, 1973a) e con cluiu-se que a diferenciação de embriōides foi reduzida com doses inferio res a $2 \mathrm{kR}$ e superiores a $20 \mathrm{kR}$ e estimulada em 12-16 kR. As doses entre 28 e 32 kR foram letais. Houve evidencia de uma correlação negativa entre diferenciação de embrióides e proliferação dé calos, esta ültima estimula da com doses inferiores a $2 \mathrm{kR}$ e inibida principalmente com doses superio res a $16 \mathrm{kR}$. 
Com uma intensidade de dose mais alta $(50 \mathrm{kR} / \mathrm{h})$, os mesmos autores observaram formação de apenas alguns embriōides (2,6 contra 23,6 na testemunha) em doses superiores a $20 \mathrm{kR}$ e, $24 \mathrm{kR}$ foi letal. A dose de $16 \mathrm{kR}$ foi testada em $100 \mathrm{kR} / \mathrm{h}$ havendo um efeito depressivo sobre o peso das culturas e número de embrióides.

A irradiação tem sido reportada baixar os niveis de auxinas (CHOUREY et alii, 1973). Isto forneceria uma explicação sobre o est ímulo a embriogênese fornecido pela irradiação (SPIEGEL-ROY e KOCHBA, 1980), quan do as auxinas seriam reduzidas a um nivel mais próximo do ótimo para dife renciação de embrióides. Por outro lado, pode-se considerar que explantes subcultivados contém vários estágios de desenvolvimento, desde células iso ladas até corpúsculos globulares e embriōides de diversos tamanhos. Espera-se que células individuais e agregados menores sejam mais sensiveis à irradiação permitindo estágios embriogênicos maiores e mais desenvolvidos e resultando no aparecimento de mais embrióides. Isto poderia explicar pelo menos em parte a variação aumentada na resposta de culturas individuais com calos em envelhecimento usados para subcultivos (KOCHBA e SPIEGELI-ROY, 1977b).

Irradiação de calos a $16 \mathrm{kR}$ com intensidade de $3,1 \mathrm{kR} / \mathrm{h}$ mos trou um efeito mais depressivo sobre o peso das culturas do que a irradia ção do meio. o número de embrióides foi o mesmo, irradiando ou não os ca los. 0 aumento no número de embrióides foi similar com irradiação dos ca los e, com irradiação dos calos e do meio (SPIEGEL-ROY e KOCHBA, 1973b).

A irradiação de certos componentes do meio pode reduzir dras 
ticamente o peso das culturas e a capacidade para diferenciação de embriōi des, como observado com irradiação do meio adicionado de adenina (20, 40 e

- $80 \mathrm{mg} / 1)$. Em meio suplementado com altas doses de cinetina $(1 \mathrm{mg} / 1)$ e IAA $(1 \mathrm{mg} / 1)$ o peso das culturas foi baixo e não houve formação de embrióides com ou sem irradiação; por outro lado, com baixas concentrações de cineti na $(0,1 \mathrm{mg} / 1)$ e $I A A(0,1 \mathrm{mg} / 1)$ a irradiação diminuiu o crescimento dos ca los, porém, estimulou notavelmente à diferenciação de embrióides.

A adição de IAA não irradiado ao calo irradiado resultou num fenômeno dependente de dose. Enquanto em baixas doses de irradiação (menos que $8 \mathrm{kR}$ ) a embriogênese foi inibida pelo $I A A$, a inibição foi gradual mente superada por doses mais altas que $8 \mathrm{kR}$ (KOCHBA e SPIEGEL-ROY, 1977b). Algumas doses de irradiação $(12-16 \mathrm{kR})$ juntamente com niveis de IAA ainda estimularam a embriogênese e aumentaram a taxa de desenvolvimento de embri óides. Usualmente doses letais $(30 \mathrm{kR})$ ainda permitiram sobrevi vência e crescimento de culturas na presença de IAA (KOCHBA e SPIEGEL-ROY, 1977b). SPIEGEL-ROY e KOCHBA (1980) postularam que com certas doses de irradiação a auxina é reduzida a niveis sub-ótimos. O IAA adicionado promoveria en tão embriogênese, como de fato foi observado.

\subsubsection{Desenvolvimento de embrióides}

Embriōides raramente germinam se são deixados unidos ao nu celo, calos ou outros embrióides. Uma véz atingido o tamanho de 3-6 mm ne cessitam ser individualizados em novo meio, pára que tenha continuidade o processo de desenvolvimento (BUTTON e BORNMAN, 1971; KOCHBA et aiii, 1972; NAVARRO e JUAREZ, 1977). 
Com a individualização hā uma proliferação dos embriōides pe lo processo de gemação (ESAN, 1973), na maioria dos casos a partir de seus hipocótilos ou células superficiais (RANGASWAMY, 1961; BITTERS et alii, 1970; KOCHBA et alii, 1972).

Nọrmalmente a formação de plântulas a partir dos embrióides é precedida primeiro pela formação de raízes e depois da parte aérea. Ocor rendo o contrário há uma inibição do desenvolvimento das raízes. Embriōi des com 4-10 mm emitem raiz dentro da 1ạ e 2ạ semanas e parte aérea dentro da 3ạ e 4ạ semana.s após a individualização (NAVARRO et aliii, 1979).

A incorporação de $\mathrm{GA}_{3}-1 \mathrm{mg} / 1$ aumenta o desenvolvimento de raízes em embrióides plenamente (RANGASWAMY, 1961; BUTTON e BORNMAN, 1971; KOCHBA et alii, 1972) e parcialmente desenvolvidos (KOCHBA et alii, 1974), enquanto que hormônios usualmente conhecidos como estimulantes do enraizamento, a exemplo do NAA e IBA, o suprimem (KOCHBAe SPIEGEL-ROY, 1976b).

$$
\mathrm{GA}_{3}-1 \mathrm{mg} / \mathrm{l} \text { acrescido de adenina }-27 \mathrm{mg} / 1 \text { promoveu o en }
$$
raizamento de $80 \%$ dos embrióides globulares $(1 \mathrm{~mm})$ e alongados que não apre sentavam radicola. Embrióides cordiformes $(3-5 \mathrm{~mm})$ com radicola parcial mente desenvolvida enraizaram em $83 \%$ dos casos, enquanto que com cotiledo nes bem desenvolvidos o sucesso foi total. O desenvolvimento de pseudobu! bilhos alongados pode ser consideravelmente aumentado com $\mathrm{GA}_{3}-10$ a $50 \mathrm{mg}$ $11+$ ADS $-54 \mathrm{mg} / 1$ (NAVARRO et alii, 1979).

0 papel do $\mathrm{GA}_{3}$ não está muito claro uma vez que não ē consi derado um fator principal na indução de raízes. Seus efeitos são explicą 
dos por duas hipóteses: 1) promove o desenvolvimento ontogenético natural dos embriōides sem primordio radicular àqueles com primordio, que então de senvolvem raízes na ausência de substâncias exógenas de crescimento e, 2) proporciona diretamente a iniciação de uma zona meristemática radicular e ou estimula o desenvolvimento de uma zona radicular existente (KOCHBA et alii, 1974).

Diversas combinações auxina/citocinina foram testadas para o desenvolvimento de embriōides (KOCHBA et alii, 1972), indicando melhores resultados a combinação cinetina $-0,1+. I A A-1,0 \mathrm{mg} / 1$ para a cv. 'Valên cia'. Esta relação favoreceu a formação de raízes, porēm, inibiu a elonga ção dos caules. Ambos os órgãos tiveram um desenvolvimento de modo geral favorecido em cinetina $-1,0^{\circ}+1 A A-0,1 \mathrm{mg} / 1 . \operatorname{Com} \mid A A-0,1 \mathrm{mg} / 1$ se obte ve $34 \%$ de enraizamento para 'Shamouti' e $41 \%$ para 'Marsh'.

\subsubsection{Variação somaclonal}

Inümeras referências tem surgido sobre a instabilidade gené tica de tecidos de plantas em cultura. As variações mais comumente obser vadas são alterações no número de cromossomos (poliploidia e aneuploidia), quebras de cromossomos e fragmentações nucleares, mutações de ponto e varia ções epigenéticas. Estas modificações podem pré-existir nos tecidos das plantas ou serem induzidas por diversos fatores como intensidade luz, tempe ratura, tempo de subcultivo e principalmente determinados componentes do meio, a exemplo do 2,4-D.

Alterações como anisocotilia, pluricotilia, sincotilia, co tilédones fasciados, alongados e corrugados, cotilëdones de diferentes ta 
manhos, embriōides com mais de 2 cotilédones e värios grạus de fusão entre embriōides, tem sido observadas em embrióides oriundos tanto diretamente do nucelo como através da formação de calos ou pseudobulbilhos (DEIDDA, 1973; JUAREZ et alii, 1976; NAVARRO e JUAREZ, 1977; STARRANTINO et alii, 1978). Porém, na maioria dos casos, embriōides anormais dão origem a plan tas normais (NAVARRO et alii, 1979).

Uma observação detalhada de plantas em casa de vegetação ob tidas por cultura de nucelos revelou que $20 \%$ tem caracteres anormais na fo Iha (JUAREZ et alii, 1976), como folhas em forma de coração, arredondadas, onduladas ou com 2 foliolos. STARRANTINO et alii (1978) tambēm observaram anomalias tais como pecíolos fasciados, folhas deformadas e pecíolos e in ternōs retorcidos.

Procurando-se fazer uma relação entre a origem dos embriōi des (nucelo, calo e gemação) e a frequência das alterações, concluiu-se que as modificações não estão ligadas ao processo de embriogênese, uma vez que nos casos em que se obteve mais de uma planta a partir do nucelo ou calo, todas apresentavam caracteristicas idênticas. As modificações devem estar relacionadas à planta mãe, variadas formas de gemação e formação do óvulo (JUAREZ et alii, 1976).

Nenhuma väriação em nūmero de cromossomos tem sido detecta da em plantas regeneradas a partir dos calos friáveis consti tuidos por corpúsculos globulares obtidos em culturas nucelares de citros. Esta aparente estabilidade genētica pode ser devida à natureza destes ca los. Diferentes da maioria dos calos de plantas, que são formados paredomi 
nantemente por células grandes, vacuoladas e parenquimatosas, com células embriogênicas apenas ocasionais, estes calos de citros compreendem células pequenas e densas, parecendo que todas são embriogênicas. Eles são considerados como uma massa de proembriōides, em vários estágios de desenvolvi mento, proliferando (BUTTON et alii, 1974). O fato de que calos de citros são habituados e não requerem fontes exógenas de reguladores de crescimen to, provavelmente também contribui para sua estabilidade.

\subsection{Melhoramento das espécies cītricas}

\subsubsection{Métodos convencionais}

Uma grande variabilidade existe dentro de Citrus e gêneros estreitamente relacionados, frequentemente interférteis. No entanto, algu mas barreiras como apomixia, esterilidade gamética e incompatibilidade im pedem sua plena utilização. 0 melhoramento por hibridação só é então efe tivo quando se usa como progenitor feminino uma cultivar monoembriônica, o que não é possível com cultivares que não produzem sementes (BUTTON e BO THA, 1975; SPIEGEL-ROY e KOCHBA, 1980).

Os embriões nucelares estão iocalizados numa situação previ legiada sob o ponto de vista nutricional e iniciam a divisão celular primei ro, impedindo o pleno desenvolvimento do zigoto (BUTTON e BOTHA, 1975).

\subsubsection{Cultura de embriões "in vitro"}

Quando há necessidade do uso de un progenitor feminino que seja poliembriônico, o desenvolvimento do zigoto pode ser assegurado ${ }^{-*}$ atra vēs de seu cultivo "in vitro". 
Cultura de embriões excisados de cultivar. poliembriônica (C. aurantium) 100-120 dias após a polinização, foi feita com sucesso por RAN GAN et alii (1969). Estes já em forma globular ou cordiforme se desenvol veram em embriões maduros e mais tarde em plântulas. Sua identificação foi assegurada tomando-se sementes oriundas do cruzamento com Poncirus trifolia ta L., cujas folhas trilobadas são um carater dominante, úteis como marca dor genético de sua descendência (CAMERON e FROST, 1968). Nesta fase ain da não se encontraram embriões nucelares.

Embriões de sementes imaturas de 'Satsuma' (C. unshiu Marc.) polinizada por P. trifoliata L., mostraram um bom desenvolvimento se isola dos aos 90 ou 120 dias após a polinização e cultivados em meio "MS" mais suco de pepino - 20\% (HORIUCHI et alii, 1976).

E vital a distinção entre ạ descendência zigótica e a nuce lar em estágios precoces, o que poderia ser resolvido com marcadores gené ticos seguros que expressassem caracteristicas morfológicas claramente de finidas, como é o caso da folha trilobada em P. trifoliata. No entanto, es te carater estā sob controle monogênico e muitas plantas são heterozigôtas (IGLESIAS et alii, 1974) e, de qualquer modo, o pólen marcador teria que ser substituido por aquele do progenitor desejado.

Uma tentativa tem sido feita para distinguir plântulas nuce lares de zigóticas em progênies híbridas de citros, através da anālise in fravermelha de óleos essenciais nas folhas (PIERINGER e EDWARDS, 1965) ou morfologia das folhas das progênies (TEICH e SPIEGEL-ROY, 1972).

Métodos bioquímicos tem sido desenvolvidos, como análise de 
flavonōides (TATUM et alii, 1974, 1978), acastanhamento enzimätico devido a pol ifenōis (ESAN e SOOST, 1976), hidrocarbonos de cadeia longa e, isoem zimas peroxidases e esterases (ESEN e SOOST, 1976; BUTTON et alii, 1976; SPIEGEL-ROY e KOCHBA, 1977). Apesar de algumas limitações devido à varia bilidade genética dos progenitores, as isoenzimas peroxidase e esterase tem sido analisadas em plântulas com 20 dias "in vitro" e oferecem boas perspec tivas para ajudar o melhorista de citros a selecionar plântulas zigóticas nos primeiros estágios de desenvolvimento das progênies (IGLESIAS et alizi, 1974).

\subsubsection{Uso de protoplastos}

0 isolamento de protoplastos com posterior regeneração de plântulas, dentre as fruteiras, foi estabelecido pela primeira vez com ci tros (VARDI et aliii, 1975). Plântulas foram regeneradas de protoplastos i solados de calos nucelares de duas cvs. de laranja ('Nucellar Shamouti' e 'Shamouti Landau'), tres de tangerina ('Murcott', 'Dancy' e Ponkan'), uma de "Grapefruit" ('Duncan'), uma de C. aurantium e limão ('Viliafranca')(VAR DI e SPIEGEL-ROY, 1982).

Este sistema pode servir tanto para futuros estudos genéticos da célula, como ser aplicado ao melhoramento dos citros induzindo muta ções pelo tratamento dos protoplastos com agentes mutagênicos e através da hibridação somática inter e intraespecífica. Uma vez assegurada a regene ração de plântulas a partir de protoplastos, caracteriza-se a potencialida de dos citros para a aplicação das técnicas de engenharia genética. 


\subsubsection{Indução de mutações}

0 melhoramento genético em citros tem sido devido, em gran de parte, à seleção de mutantes ocorrendo naturalmente (CAMERON e EROOST, 1968). São citados muitos casos de novas variedades desenvolvidas a par tir de mutações de gemas (CAMERON e SOOST, 1969; HENSZ, 1972). 0 uso de agentes mutagênicos forneceria uma valiosa técnica para aumentar a frequên cia de mutações, e pode, eventualmente, se tornar tão importante quanto os esforços de melhoramento pelos métodos convencionais (SPIEGEL-ROY e KOCHBA, $1973 a, 1975)$.

\subsubsection{Irradiação de tecidos multicelulares}

Uma mutação é um evento em uma única célula, a qual se é me ristemātica darā origem a uma linhagem de células mutadas, enquanto as cé lulas adjacentes permanecem invariäveis. 'A mistura de células geneticamen te diferentes (quimera) raramente pode ser evitada quando órgãos multicelü lares tais como sementes ou gemas são submetidos a tratamentos mutagênicos. Dependendo da proporção e tamanho da linhagem de células mutadas em um ör gão como um ramo formado de gema lateral, a.expressão fenotípica do carater mutante é propenso à instabilidade.

Além do ma.is, devido à perda de vigor causada por muitas mu tações, a linhagem de células mutadas tende a ser mascarada pelo tecido nor mal e, então, nunca vem a ser expressa, um fenômeno denominado seleção di plôntica. A seleção recorrente de gemas tem sido designada para resolver quimeras e superar a perda de mutações por seleção diplôntica, porém, ain da que com algum efeito é trabalhosa e cara (NYBOM, 1970; KOCHBA et alii, 
1980).

\subsubsection{Irradiação de tecidos nucelares}

A origem dos embriōides é de fundamental importância para que a cultura de tecidos possa ser associada às técnicas de indução de mu tações. Eles precisam ser derivados de células individuais e não de cen tros meristemāticos semelhantes à gema, para permitir o desenvolvimento de mutantes sōlidos após tratamentos mutagênicos.

A.perda de mutações por formação de quimeras e seleção di plôntica seria efetivamente superada aplicando o tratamento mutagênico à primeira célula destinada a dar origem a uma planta, como é o caso do nuce lo em um estāgio que antecedè a diferenciação dos embriōides. Assim sendo, a cultura de óvulos e nucelos de cultivares de citros pode ser de grande importância, uma vez que embrióides se originam de uma única célula e que plantas viäveis são posteriormente estabelecidas (BUTTON e KOCHBA, 1977). Entretanto, nucelos no estāgio adequado de desenvolvimento são disponíveis em periodo curto, sua extração é tediosa e, é baixo o número de plan tas formadas.

Experimentos foram desenvolvidos com nucelos de óvulos não fertilizados e não diferenciados de 'Shamouti' (SPIEGEL-ROY e KOCHBA, 1973b), extraídos 4 semanas após a ântese e irradiados por ocasião da inoculação e, 2 e 4 semanas depois. A percentagem de culturas com sucesso foi maior com irradiação após 2 semanas da inoculação. 0 nümero médio de embriōides por cultura foi um tanto mais al to que a testemunha nas doses de 0,5 e $1,0 \mathrm{kR}$ em culturas irradiadas por ocasião da inoculação ou 4 semanas depois. 


\subsubsection{Irradiação de calos nucelares}

As vantagens da cultura de tecidos e células para indução e seleção de mutantes tem sido amplamente revisadas (MELCHERS, 1972; BOTTINO, 1975; SPIEGEL-ROY e KOCHBA, 1977). A manipulação de um grande número de células/genōtipos em um espaço limitado é atrativa, comparada com a deman da de espaço no melhoramento convencional. .

Um calo embriogênico subcultivado pode ser usado efetivamen te e independentemente de restrições sạzonais. A capacidade para embriogê nese tem sido demonstrada se manter mesmo após 8 anos de subcultivos (BIIT TON et alii, 1974). A origem unicelular de embrióides que se desenvolvem nos calos nucelares"da cultivar 'Shamouti' (C. sinensis), foi evidenciada por BUTTON et alii (1974) em estudos de microscopia eletrônica, com poste rior regeneração de plantas.

Trabalhos tem sido desenvolvidos (KOCHBA et ali.i, 1980) com o uso de raios gama $(8,12$ e $16 \mathrm{kR}$ a $80 \mathrm{kR} / \mathrm{h})$ sobre calos nucelares, obje tivando tolerância a niveis mais elevados de $\mathrm{NaCl}$ e 2,4-D. Calos de 'Sha mouti' foram expostos a irrradiação gama $(12 \mathrm{kR})$, transferidos para meio con tendo $\mathrm{NaCl}-0,2 \mathrm{M}$, dos quais se obteve colônias de células capazes de cres cer na presença de $\mathrm{NaCl}$ nesta concentração (BEN-HAYYIM e KOCHBA, 1982).

Células isoladas foram obtidas a partir de calos (BUTTON e BOTHA, 1975), as quais podem ser sujeitas a tratamentos mutagênicos, abrin do a possibilidade de aplicar métodos usados na seleção de mutantes em mi crorganismos (DEVREUX, 1973; HEINZ, 1973). Células mutantes se reorganiza riam em plantas inteiras em que todas as células seriam portadoras da muta 
ção.

Tem-se à mão para citros um sistema "da cēlula à planta" e seu uso para o melhoramento teria grande impacto com respeito ao estabele cimento de novas cultivares de valor. Desde que agora se tem possibilidade de manusear qualquer número de células (genótipos), algumas das limita ções presentes ao melhoramento das fruteiras seriam superadas.

\subsubsection{Agentes mutagênicos em protoplastos}

Protoplastos isolados de calos obtidos de óvulos não fertí lizados foram tratados com etil metano sulfonato (EMS) e raios $\mathrm{X}$ (VARDI et alii, 1975). A irradiação com $1.500 \mathrm{R}$ não diminuiu significativamente o número de colônias. Metade da sobrevivência foi atingida em torno de 3.400 R. Somente $14 \%$ das colônias desenvolveram após o tratamento com $6.000 \mathrm{R}$, quando comparadas à testemunha. Irradiação X (4.500 a 7.500 R) promoveu a diferenciação de embriōides, o que não se verificava em protoplastos não irradiados. Exame citológico mostrou que estes calos se mantiveram consis tentemente diplöides $(2 n=18)$.

Colónias altamente embriogénicas foram obtidas a partir de protoplastos isolados e irradiados (VARDI e SPIEGEL-ROY, 1982), o que favo rece a suposição de um efeito direto da irradiação sobre as células.

\subsubsection{Agentes mutagênicos em plântulas decapitadas}

Plântulas decapitadas na presença de alta umidade relativa formam calos na superfície do caule, originando gemas adventícias. - Plân tulas com aproximadamente $5 \mathrm{~cm}$ de altura e 4 folhas foram submetidas a ra 
diação gama ( 0 a 8 kR). Somente $15 \%$ das plântulas geraram novas gemas em $4 \mathrm{kR}$ e, $8 \mathrm{kR}$ foi letal. O método prestar-se-ia bem para a produção de mu tantes sōlidos e é também mais fäcil que a cultura "in vitro" (SPIEGEL-ROY e KOCHBA, 1973a).

Gemas adventícias e embriōides globulares são formados em plântulas nucelares "in vitro" na presença de $N A A-1,0 \mathrm{mg} / 1+B A-5,0 \mathrm{mg} / 1$. A região intermediāria entre a raiz e a parte aérea de P. trifoliata foi tratada com EMS-0,3\% e transplantada para me io contendo $\mathrm{NaCl-0,2M}$ (MATSUMO TO, 1983). Foram obtidas linhagens com vārios graus de tolerância ao $\mathrm{NaCl}$.

\subsubsection{Seleção de mutantes}

A anālise genētica de populações $F_{1}$ e $F_{2}$ de plantas férteis de citros, obviamente seria dificil devido à prolongada fase juvenil e por causa da poliembrionia. Mas, uma vez regẻnerada uma planta mutante desejā vel e estável, se ela representa uma mutação sōlida ou uma variação epige nética na expressão gênica, ela pode ser mantida e multíplicada por propa gação clonaì.

A utilização do valor potencial de cultura de células para seleção de mutantes se defronta com considerāveis dificuldades. Métodos efetivos de seleção para a detecção precoce e isolamento de mutantes dese jāveis precisam ainda ser desenvolvidos.

Um sistema de seleção com sucesso potencial pode agir a um nivel celular. Expressões fenotípicas dependentes de características es truturais e funcionais de um örgão inteiro da planta, a exemplo de certos 
tipos de resistência a doenças ou herbicidas, tão bem como mutantes auto e auxotröficos (WHIDHOLM, 1978), seriam selecionados somente se coincidem com processos definidos a um nivel celular ou de genes.

Estão em estudo para citros sistemas modelos de seleção pa् ra resistência a salinidade, estreptomicina e herbicidas (KOCHBA e SPIEGEL $-R O Y, 1982)$. Mutantes para outras caracteristicas, tais como häbitos de crescimento e frutificação teriam que ser selecionadas num estägio poste rior de desenvolvimento.

\subsection{Propagação vegetativa "in vitro"}

\subsubsection{Micropropagação}

- Uma vez identificado um mutante com características de inte resse, este precisa ser multiplicado em grande escala e rapidamente, o que é possivel com o uso das técnicas de cultura de tecidos. A similaridade na resposta entre gemas crescidas "in vivo" e "in vitro" é significante, o que permite também o estudo "in vitro" de fatores que controlam fenômenos complexos tais como diferenciação e desenvolvimento de gemas florais (ALT MAN e GOREN, 1977).

A micropropagação nas espécies citricas pode ser feita "'in vitro" através da cultura de äpices caulinares e gemas axilares, desde que The sejam propiciadas condições ideais, principalmente no que diz respeito a meio de cultura.

Anteriormente a remoção dos explantes, procede--se uma cuida dosa assepsia dos ramos (GIJADI et aliii, 1979), através de imersão em eta 
nol-80\% por 5 minutos e posteriormente, em hipoclorito de cälcio filtrado $-9 \%$ adicionado de "tween" $20-0,01 \%$, por 20 minutos. Este procedimento se prende ao fato de que as plantas no pomar são altamente sujeitas a contami nação por bactérias e fungos, que podem estar profundamente localizados nos tecidos e que, quando em presença de um meio nutriente enriquecido, seu de senvolvimento é acelerado a um grau que pode interferir com a resposta do explante.

Um bom desenvolvimento de gemas latentes foi obtido em meio "MS" adicionado de cinetina + NAA-1,0 mg/l (BOUZID, 1975). Uma gema de C. grandis cultivada em me io "MS" modificado por CHATURVEDI e MITRA (1974) e suplementado por $B A-0,25+N A A-0,1 \mathrm{mg} / 1$, produziu 20-30 novas gemas e todas desenvolveram brotos.

Diversos reguladores de crescimento foram adicionados ao meio "MT" (ALTMAN $\in$ GOREN, 1977), no qual foram inoculadas gemas extraídas de árvores adultas cultivadas em pomar e jovens em casa de vegetação. 0 IAA atrasou a brotação e aumentou levemente a elongação, enquanto que $\mathrm{GA}_{3}$ promoveu a elongação dos internós. BA e cinetina induziram a formação de mais que 6 gemas adventícias em lugar de 2 que normalmente desenvolvem. A desfolhação da planta antes da coleta das gemas estimulou o crescimento "in vitro" de novos brotos.

Ápices caulinares de C. microcarpa Bunge mesmo com menos de $1 \mathrm{~mm}$, cultivados em meio "White" suplementado por adeniná-40 mg/l ou leite de côco-40\% ( $/ / v)$, se alongaram e produziram follhas dentro de 4 semanas. Ápices maiores que $1 \mathrm{~cm}$ cresceram mais rápido sobre meio "White" acrescido 
de adenina-40 mg/1 ou IAA-5 mg/l (RANGASWAMY, 1975). •

Nós e entre-nós com menos de $1 \mathrm{~cm}$ de ramos jovens e adultos de diversas cultivares foram inoculados em meio sōlido ("MS" com BA-2,0 mg 11) e āpices caulinares em meio líquido ("MS" integral ou 1/2 da concentra ção adicionado de $\mathrm{BA}-0,5$ a $2,0 \mathrm{mg} / \mathrm{l})$, e mantidos à luz por 15 hs a $27^{\circ} \mathrm{C}$ e 9 hs no escuro a $20^{\circ} \mathrm{C}$ (BARLASS e SKENE, 1982). Os äpices evidenciaram un crescimento muito modesto. Os entre-nōs de plântulas jovens produziram ramos prontamente, porém, nos adultos não houve crescimento. A mais proli fica fonte de brotos para todas as variedades foram as gemas axilares dos nös, tanto jovens quanto adultos.

\subsubsection{Indução de calos em segmentos da planta}

Calos tem sido obtidos em meio "MS" ou "MT" a partir de seg mentos de folha, caule e ápices caulinares de C. paradisi Macf. com adi ção de NAA-0,5 mg/l (ALTMAN e GOFIN, 1971; BHANSALY E ARYA, 1978), de C. grandis com cinetina-0,25, NAA-2,5+2,4-D-0,25 mg/l (CHATURVEDI e MITRA, 1974), de C. limettioides adicionado de $2,4-D-0,25 \mathrm{mg} / 1+B A-0,1$ ou 1,0 $\mathrm{mg} / \mathrm{l}$ (BHANSALY e ARYA, 1979).

0 me io "White" suplementado por $2,4-D-5 \mathrm{mg} / 1$ produziu calos em äpices caulinares de C: microcarpa Bunge. Neste mesmo meio adicionado de caseina hidrolizada-400 mg/l ou cinetina-0,02 mg/l, a base da folha tam bēm produziu calos, porēm, sem organogênese. Houve formação de calo na ex tremidade de plântulas decapitadas e crescidas "in vitro" sobre o meio "Tu key" (RANGASWAMY, 1975). 


\subsubsection{Organogênese em calos}

Citocininas, de modo geral, aumentam o estímulo à formação de gemas adventicias (GRIMBLAT, 1972; MITRA e CHATURVEDI, 1972).

Melhores resultados na organogênese de calos, com atē 30 bro tos por explante, tem sido obtidos em meio "MT" adicionado de BAP-0,5 + NAA $-0,15+E M-1000 \mathrm{mg} / 1$ para C. paradisi Macf. (ALTMAN e GOREN, 1974) e de $B A-10+N A A-0,1+E M-500 \mathrm{mg} / 1$ para C. madurensis (GRIMBLAT, 1972); em me io "MS" adicionado de BAP-1,0 + cinetina-0,25 mg/1, ou BAP-1,0 + cinetina-0,25 $+I A A-0,2 \mathrm{mg} / 1$, ou BAP-0,5 + cinetina-0,25+NAA-0,2 + EM-500 mg/l para C. limettioides (BHANSALY e ARYA, 1979); em meio "MS" modificado por CHATURVE DI e MITRA (1974) com metade da concentração de vitaminas, suplementado por $B A-0,25 \mathrm{mg} / 1$, ou $B A-0,25+N A A-0,1+E M-500 \mathrm{mg} / 1$ para C. grandis (BHANSALY $e$ ARYA, 1979).

Houve diferenciação de genas em todas as combinações de BA $(0,1$ a $10 \mathrm{mg} / 1)+N A A(0,1$ a $0,2 \mathrm{mg} / 1)+E M(500$ e $1000 \mathrm{mg} / 1)$. A formação de gemas, brotos e embriōides foi estimulada pela adição de zeatina-0,1 a $0,3 \mathrm{mg} / 1$ ao meio (CHATURVEDI e MITRA, 1974; CHATURVEDI et alii, 1974).

\subsubsection{Enraizamento dos brotos}

Apōs a diferenciação das gemas e elongação dos brotos, estes são separados e transferidos para meio de enraizamento.

Brotos obtidos de calos de C. grandis (CHATURVEDI e MITRA, 1974) menos vigorosos enraizaram em meio "MS" modificado e adicionado de $\mathrm{NAA}-0,1 \mathrm{mg} / 1$, enquanto que os mais vigorosos requereram $\mathrm{NAA}-0,5$ ou $\mathrm{NAA}-0,25$ $\mathrm{mg} / 1+$ IBA. Primordios de raiz foram visiveis com 10-30 dias de incubação. 
Rizogênese de brotos oriundos de calos de. C. limettioides só ocorreu quando estes foram excisados e colocados em meio "MS" com NAA-0,1 a $2,5 \mathrm{mg} / 1+$ cinetina-0,1 mg/1 + sacarose-2\% (BHANSALY e ARYA, 1979). Bro tos com mais de $1 \mathrm{~cm}$ obtidos "in vitro" por BARLASS e SKENE (1982) a par tir de nōs, entre-nós e ápices caulinares de diversas variedades, enraiza ram em meio "White" com altos níveis de auxina (NAA-1,8 a 4,6 mg/1).

Uma única raiz foi produzida a partir de ápices caúlinares de C. microcarpa Bunge cultivados em meio "White", adicionado de adenina $-40 \mathrm{mg} / 1$ ou IAA-5 mg/1 (RANGASWAMY, 1975), enquanto em segmentos interno dais houve a produção de 2-4 raízes por explante. 0 primeiro par de folhas de plântulas crescidas "in vitro" foi excisado e cultivado sobre meio "Whi ite" suplementado por IAA-5 mg/l, diferenciando 2 raízes na base da fo Iha durante a 1 ạ semana e, em 10 dias, as raízes foram proeminentes.

\subsection{Cultura de segmentos do fruto}

Calos derivados de tecidos de frutos permitem estudos de fe nômenos morfolögicos, citológicos e fisiolögicos (SCHROEDER e SPECTOR, 1957; SCHROEDER et alii, 1962; KORDAN, 1963, 1965٪.

E possivel se investigar a biossíntese de öleos essenciais no flavedo (BRUNET e IBRAHIM, 1973) eo fundamento básico do acumulo de açü cares e àcidos.

0 enrugamento de frutos cítricos, por exemplo, é devido a expansão continuada e excessiva do endocarpo apös ter cessado a divisão ce lular do mesocarpo (albedo) causando sua ruptura, o que torna o fruto par 
ticularmente sensivel à infecções de fungos e bactērias. Tem sido mostra do (GILFILLAN et alii, 1974) que pulverizações de $\mathrm{GA}_{3}$ podem reduzir grande mente a incidência de enrugamento, possivelmente devido a promoção da divi são celular pelo $\mathrm{GA}_{3}$, como anteriormente descrito por SCHROEDER e SPECTOR (1957) em um sistema "in vitro".

A cultura de tecidos pode fornecer um adequado instrumento de estudo de respostas morfolögicas e desequilibrios nutricionais. Por exemplo, foi criado por BAR-AKIVA et alii (1974) um modelo "in vitro" para tentar resolver o problema da "casca grossa" causada por altos níveis de potássio (K). Observou-se que baixos niveis de $K$ foram associados a altas concentrações de putrescina e vice-versa. Adicionando putrescina no meio com elevada concentração de $\dot{k}$, foi possivel reduzir grandemente a prolife ração de calos da casca. Quando putrescina foi aplicada en pomares onde $\mathrm{K}$ provocava "casca grossa" observou-se uma acentuada redução do problema.

Proliferação de calos a partir de albedo foi obtida no meio "White" adicionado de IAA-5 mg/l (RANGASWAMY, 1961) e aumentada pela adi. ção de glicina-2 a $4 \mathrm{mg} / \mathrm{l}$ (MURASHIGE e TUCKER, 1969).

Foram observados efeitos significativos do suco de laranja $-10 \%$ adicionado ao meio "MT" sobre o crescimento de calos de albedo na cul tivar 'Shamouti' e C. Limon Burm.f., e ao meio "MS" em C. Liman Burm.f., C. medica e C. reticulata Blanco (MURASHIGE e TUCKER, 1969). 0 äcido cr trico-2 mg/l, que é o componente natural do suco de laranja, mostrou poder substituir pelo menos em parte a atividade promotora de crescimento do su co de laranja, parecendo ser responsável pela maior parte da atividade de 
crescimento do suco (ERNER et alii, 1975).

Segmentos de albedo $(20 \mathrm{mg})$ foram cultivados "in vitro"(EIN SET, 1978) sobre meio "MS" adicionado de 2,4-D + cinetina-0,5 mg/1 + suco de laranja lima centrifugado, mantidos no escuro. Em C. medica, IAA e $G_{3}$ mostraram um efeito sinérgico na proliferação de calos (SCHROEDER e SPECTOR 1957); afirma-se que a capacidade para proliferar è comum ao pericarpo ma duro de quase todas as espécies frutiferas subtropicais lenhosas (LETHAN, 1958; SCHROEDER et alii, 1962).

Bom crescimento de calos oriundos de vesículas foi observa do com a adição de 2,4-D $(1,0 \mathrm{mg} / \mathrm{l})$ e a citocinina SD $8339(10 \mathrm{mg} / \mathrm{l})$ ao meio "N," para C. limon Burm. $f ., C$. sinensis 0sb. e C. reticulata Blanco (NITSCH, 1965). Resultados positivos também se evidenciaram em meio "Whi te" adicionado de EM-0,5\% ou $\mathrm{GA}_{3}-2 \mathrm{mg} / 1$ (RANGASWAMY, 1961).

Calos foram induzidos a partir de vesículas de C. acida em meio "MS" acrescentado de cinetina-1,0 mg/l + 1 AA-10 mg/l (PAREKH e METHA, 1970) e de $C$. sinensis $c v$. 'Valência' com cinetina-1,0 mg/1 + $\mid A A-2,0 \mathrm{mg} / 1$ (UNGER é FENG, 1978), mant.idos à luz. A adição de cinetina-0,5 mg/l + 2,4-G $2,0 \mathrm{mg} / 1$ + suco de laranja lima-10\% também permitiu a formação de calos. 0 suco de laranja aumentou significativamente o crescimento de calos em C. medica, C. limon Burm.f., C. paradisi e C. sinensis 0sb. (MURASHIGE e TUCKER, 1969).

Formação de calos a partir de vesículas de frutos maduros e imaturos também foi verificada em C. hassaku, Hort. ex Tanaka (KATO, 1980), em meio "MS" acrescido de $1 A A-1,7+B A-0,4 \mathrm{mg} / 1$, ou $\mid A A-1,7+$ cinetina-0,4 $\mathrm{mg} / 1$, ou 2,4-D-0,6+2ip-1,5 mg/1, ou ainda 2,4-D-0,6+cine 
tina-0,4 mg/l. Alguns calos mantidos por 15 semanas sem subcultura pesa ram em médio $1,4 \mathrm{~g}$ e mediram 10-15 mm de diâmetro. Acido cítrico e ácido málico inibiram completamente a proliferação.

Em nenhum meio de cultura se conseguiu regeneração de plan tas a partir de calos de albedo e vesículas.

\subsection{Remoção das plantas para o solo}

Plantas obtidas tanto por embriogênese como por organogêne se pödem ser levadas ao solo quando apresentarem 3-4 pares de folhas. AI tas perdas ocorriam durante este processo de transplante dos tubos de en saio para o solo (SINGH, 1963; BITTERS et alii, 1970; BUTTON e BORNMAN, 1971). No entanto, $90 \%$ de sobrevivência pode ser obtida utilizando o méto do proposto para plântulas microenxertadas (NAVARRO et alii, 1975): As plântulas com aproximadamente $3 \mathrm{~cm}$ são removidas dos tubos para potes con tendo um substrato esterilizado formado por areia fina e terra preta $(1: 1)$. 0s potes são protegidos por um saco plástico transparente para reduzir a perda de umidade e colocados em área sombreada em casa de vegetação. Após uma semana os sacos são abertos e, na segunda semana removidos e as plântú las deixadas a crescer sob condições normais de casa de vegetação.

A perda de plântulas quando da transferência para o solo é atribuida a 2 fatores fundamentais (CAILLOUX, 1984): 1) as plântulas podem perder quantidades excessivas de água porque elas não tem desenvolvidos sis temas apropriados para a incorporação e conservação de água e, 2) raízes formadas em agar não são funcionais quando transplantadas para o sơio, ha vendo a necessidade do desenvolvimento de novas raizes. 
Plântulas de citros obtidas por cultura de tecidos tendem a ter um crescimento lento e são comparativamente fracas "in vivo" sobre suas prōprias raízes, mesmo depois de terem se estabelecido plenamente no solo (NAVARRO e JUAREZ, $1977 a, b)$. O problema tem sido contornado com o uso de enxertia.

Gemas da porção terminal sem espinhos de plântulas de 'Nave lina' e 'Staggs Bonanza' obtidas por cultura de óvulos não fertilizados fo ram enxertadas sobre citrange 'Troyer' e plântulas de laranja doce, am bos com 4 anos de idade. Dois anos após a enxertia as plantas produziram os primeiros frutos (STARRANTINO e RUSSO, 1983).

Tem sido sugerido (STARRANTINO et alii, 1978) que plântulas com 4-5 folhas, obtidas de pseudobulbilhos oriundos de cultura de tecido nucelar, sejam transferidas para solução de Hoagland, adicionada de $\mathrm{GA}_{3}-10$ $\mathrm{mg} / 1$, por $2-4$ semanas antes de irem para a terra. Chama-se a atenção para - fáto de que se as plantas forem deixadas em $\mathrm{GA}_{3}$, seus brotos se tornam longos e em.forma de fuso e invariavelmente morrerão quando transplantadas para o solo. Após a formação de raízes e iniciado o desenvolvimento de ra mos, as plântulas seriam transferidas para outro meio sem $\mathrm{GA}_{3}$ para evitar o desenvolvimento de plântulas fracas. Concentrações de Fe (quelatos) mais altas que as normais evitam cloroses (BUTTON e BORNMANN, 1971; NAVARRO et alii, 1979). 
.39 .

\section{MATERIAL E METODOS}

Os experimentos foram conduzidos junto às Seções de Radioge nética e Bioquímica de Plantas do Centro de Energia Nuclear na Agricultura (CENA), örgão da Universidade de São Paulo (USP), em Piracicaba-SP.

Os frutos e flores das cultivares 'Valência' e 'Pera Bian chi' (Citzus sinensis 0sb.) utilizados para extração de nucelos e óvulos e frutos de 'Trifoliata' (Poncirus trifoliata Raf.) para extração das semen tesi, foram obtidos junto à Estação Experimental de Limeira, Lnidade do Ins ti tuto Agronômico de Campinas (IAC), em Cordeiröpolis-SP.

0 desenvolvimento do presente trabalho se deu concomitante mente à montagem do laboratório de cultura de tecidos da Seção de Radioge nética, exigindo a improvisação de determinados procedimentos, o que pode eventualmente ter interferido em alguns resultados.

\subsection{Assepsia}

A assepsia dos frutos e flores foi procedida a partir de uma raspagem da superfície externa (para os frutos), foram lavados primeiramen te em àgua corrente, a seguir em solução de ãgua e detergente e, esteri li 
.40 .

zados com hipoclorito de sódio- $2 \%$ durante 20 minutos. Posteri ormente, em condições assēpticas, fizeram-se 3 lavagens com àgua destilada autoclavada. As gemas axilares utilizadas para a micropropagação foram obtidas de plântulas produzidas "in vi tro" e portanto, jà estavam assépticas.

\subsection{He io de cultura}

0 meio de cultura utilizado se constituiu (em mg 11) dos macronutrientes do meio "MS": $\mathrm{NH}_{4} \mathrm{NO}_{3}-1650, \mathrm{KNO}_{3}-1900 \ldots$, $\mathrm{CaCl}_{2} \cdot 2 \mathrm{H}_{2} \mathrm{O}-440, \mathrm{MgSO}_{4}, 4 \mathrm{H}_{2} \mathrm{O}-370, \mathrm{KH}_{2} \mathrm{PO}_{4}-170, \mathrm{Na}_{2} \mathrm{EDTA}-37,3$, $\mathrm{FeSO}_{4}$. 7 $7 \mathrm{H}_{2} \mathrm{O}-27,8$; dos micronutrientè do meio "MS": $\mathrm{MnSO}_{4} .4 \mathrm{H}_{2}$ $0-22,3 ; \mathrm{ZnSO}_{4} \cdot 7 \mathrm{H}_{2} \mathrm{O}-8,6 ; \mathrm{H}_{3} \mathrm{BO}_{3}-6,2 ; \mathrm{KI}-0,83 ; \mathrm{Na}_{2} \mathrm{MoO}_{4} \cdot 2 \mathrm{H}_{2} \mathrm{O}-0,25 ;$ $\mathrm{CuSO}_{4} \cdot 5 \mathrm{H}_{2} 0-0,025 ; \mathrm{CoCl}_{2} \cdot 6 \mathrm{H}_{2} 0-0,025$ e foi adicionado de: tiami na $\mathrm{HCl}-0,2$; piridoxina $\mathrm{HCl}_{-1,0}$; ácido nicotínico-1,0; meso ino sitol-100; EM-500 e sacarose-50.000 - meio bäsico "MS". Em a I guns casos foi usado o meio "MT", que difere do meio básico "MS" apenas nas concentraçöes de vitaminas (tiamina HCl-10, PI ridoxina HCl-10 e äcido nicotínico-5 mg/l) e não possui EM. 0 pH foi ajustado para 5,7, o meio solidificado com bacto agar $8 \mathrm{~g} / \mathrm{l}$ e autoclavado a $120^{\circ} \mathrm{C}$ por $20 \mathrm{minutos}$.

3.3. Condições de crescimento

A maior parte das culturas foi mantida à luz (aproximadamen 
te 1500 lux) durante 16 horas diärias e uma temperatura em torno de $27^{\circ} \mathrm{C}$. 0 delineamento experimental utilizado em todos os experimentos foi o inte ramento casualizado. Para efeitos de anälise estatística os dados de con tagem foram transformados em $\sqrt{x+0,5}$ e os de percentagem em arc sen $\sqrt{x+0,5}$

3.4. Cultura de nucètos de 'Valência'

\subsubsection{Extração do nucelo}

Frutos da cultivar 'Valência' com aproximadamente 12 semanas após a polinização foram cọtados em condições assépticas, e os óvulos re movidos foram colocados em placas de Petri esterilizadas. Com auxilio de bisturi e sob estereomicroscópio, através de um corte longitudinal no óvulo, removeram-se os integumentos e, com um corte transversal na região micropi lar do nucelo, procedeu-se a eliminação dó embrião zigótico.

Esporadicamentè, por ocasião da inoculação, se observaram al guns embrióides, os quais foram eliminados. Isto mostra que este seria o prazo máximo para extração de nucelos da cultivar 'Valência', posteriormen te a isso o nucelo jā teria diferenciado os embriōides.

\subsubsection{Diferentes concentrações de auxina/citocinina}

Os nucelos foram colocados individualmente em frascos conten do $10 \mathrm{ml}$ do meio básico "MS" adicionado de todas as combinações possíveis de $\operatorname{Cin}(0,0 ; 0,25 ; 0,50 ; 1,0 ; 1,5 \mathrm{mg} / 1)$ e $2,4-D(0,0 ; 0,5 ; 1,0 ; 2,0 \mathrm{mg} / 1)$. Das 20 repetições, 10 foram expostas à luz e 10 mantidas no escuro. - 
A avaliação foi feita quanto ao número de embriōides por nu彑 celo, e as percentagens de enraizamento dos embrióides e de nucelos que apresentaram calos.

\subsubsection{Irradiação de tecido nucelar}

Cada nucelo foi inoculado em um tubo de ensaio $(10 \times 2 \mathrm{~cm})$ contendo $10 \mathrm{ml}$ do meio bāsico "MS". A irradiação foi feita com raios gama da fonte de ${ }^{60}$ Co do CENA-USP, nas doses de 0,$5 ; 1,0 ; 2,0 ; 4,0 ; 8,0$ e 12,0 kR, a uma intensidade de $97 \mathrm{kR} / \mathrm{h}$, em cada um dos seguintes experimentos:

1) Os nucelos juntamente com o meio de cultura foram irradiados em dife rentes fases:

- por ocasião da inocułação ...... tratamento $A$

- uma semana após a inoculação ..... tratamento B

- duas semanas após a inoculação .... tratamento $C$

- três semanas após a inoculação ..... tratamento $D$

- sem irradiação . . . . . . . tratamento testemunha

2) Foram efetuados diversos tratamentos por ocasião da inoculação:

- irradiação do meio ........ tratamento E

- irradiação do nucelo ........ tratamento $F$

- irradiação do meio e do nucelo .... tratamento G

- sem irradiação .......... tratamento testemunha

Obs.: 0 tratamento testemunha é o mesmo para ós 2 experimentos e o trata mento $G$ do experimento 2 corresponde ao tratamento $A$ do experimento 1. 
Usaram-se 20 repetições mantidas à luz e foram efetuadas as seguintes avaliações: número de embriōides por nucelo e percentagens de nu celos com calos, de embrióides com raiz e de deformações nos cotilédones.

\subsection{Cultura de övulos abortivos de 'Pera'}

\subsubsection{Diferentes fases de desenvolvimento}

Foram utilizadas flores da cultivar 'Pera Bianchi' imediata mente antes da ântese e frutos com as seguintes medidas médias (comprimen to $\times$ espessura em $\mathrm{cm}$ ): $0,95 \times 0,77 ; 1,25 \times 1,02 ; 1,62 \times 1,60 ; 2,55 \times 2,29$; $3,38 \times 3,02$, colhidos numa mesma época. O meio de cultura foi o "MS" e usaram-se 10 repetições à luz e 10 no escuro.

0 experimento foi avaliado pelo nümero de embrióides por ón lo e pela percentagem de óvulos com calos.

\subsubsection{Diferentes meios de cultura}

Foram utilizados frutos da cultivar 'Pera Bianchi' com apro ximadamente $3 \mathrm{~cm}$ de diâmetro. Os óvulos foram inoculados em meio "MS" adi cionado de um dos seguintes tratamentos (em $\mathrm{mg} / \mathrm{I}$ ): a) AA-40; b) EM-500; c) $E L-500$; d) $A C-10 \%$; e) $C H-400$; f) $A D-40$; g) $A D-40+E M-500$; h) $A D-40+N A A-$ $0,25+A C i-2,0$; i) $A D-40+C i n-0,25$; j) $(i n-0,5+2,4-D-2,0$. As 10 repet ções foram mantidas à luz.

Avaliou-se o número de embrióides por óvulo e a perceritagem de embrióides com plântulas e calos. 


\section{.44 .}

3.6. Cultura de calos de 'Valência'

Calos friáveis formados em sua maioria por corpúsculos glo bulares (pseudobulbilhos) obtidos a partir de nucelos inoculados em meio irradiado principalmente com $12 \mathrm{kR}$, foram subcultivados periodicamente (a intervalos de aproximadamente 6 semanas), no mesmo meio básico "MS" e man tidos à luz.

\subsubsection{Desenvolvimento de pseudobulbithos}

Foram testados os seguintes componentes adicionados ao meio "MS" (em mg/l): a) meio "MS"-testemunha; b) EM-2500; c) EM-2500 + ADS-30; d) $E M-2500+B A P-20$; e) $A D S-40$; f) $G_{3}-1$; g) $G_{3}-1+A D S-30$; h) $G A_{3}-10+$ ADS-60; i) $G_{3}-10$; j) $(i n-0,1+(A A-1 ;$ k) Cin-1 + (AA-0,1; 1) $A C-10 \%$; m) $\mathrm{CH}-400+$ EL-500. Em cada frasco contendo $20 \mathrm{ml}$ do meio colocaram-se 20 pseudobulbilhos e foram usadas 10 repetições mantidas à luz.

Após 50 dias da inoculação, o experimento foi avaliado quan to ao número de embrióides e proembrióides diferenciados, e percentagem de culturas apresentando crescimento de calos.

3.6.2. Irradiação de calos globulares (pseudobulbilhos)

Calos friáveis com corpúsculos globulares (pseudobulbilhos) obtidos de cultura de nucelos e óvulos foram submetidos à irradiação nas doses de $0,3,6,9,12,15,18,21,24,27,30$ e $33 \mathrm{kR}$ a uma intensidade de $97 \mathrm{kR} / \mathrm{h}$. Como avaliação, foi contado o número de embrióides diferencią dos por cultura e registrada a percentagem de embrióides anormais. 
3.7. Individualização de embriōides

\subsubsection{Processo seguido para todos os experimentos}

Após aproximadamente 9 semanas da irioculação de nucelos e 12 da inoculação de óvulos, os embrióides atingindo um tamanho de 4-12 mm eram individualizados em tubos de ensaio $(20 \times 2 \mathrm{~cm})$ contendo $15 \mathrm{ml}$ do meio bāsico "MS".

\subsubsection{Enraizamento de embriōides de 'Valência'}

Embrióides oriundos diretamente de nucelos foram colocados individualmente em tubos contendo o. meio "MS" adicionado de (em mg/l): NAA $-0,1$ ou 1,$0 ; \mid A A-1,0 ; \mathrm{GA}_{3}-1,0$ ou $\mid \mathrm{BA}-1,0$.

Embrióides pequenos (menores que $3 \mathrm{~mm}$ ), médios $(3-6 \mathrm{mn}$ ). e grandes (maiores que $6 \mathrm{~mm}$ ) oriundos de calos nucelares foram inoculados em meio "MS" adicionado de (em mg/l): NAA-0,1; 1,0 ou 5,$0 ; \mid$ IAA- 1,$0 ; \mid$ BA-1,0; $\mathrm{GA}_{3}-1,0$ ou 5,$0 ;$ ADS $-27,0$ ou $\mathrm{GA}_{3}-1,0+$ ADS $-27,0$.

Em ambos os casos foram usadas 10 repetições cada uma cons tituida de 5 embrióides. A avaliação foi feita através da percentagem de enraizamento em relação aos tubos remanescentes (eliminados os que apresen tavam contaminação).

3.8. Propagação clonal de 'Valência' e 'Trifoliata'

3.8.1. Multiplicação de gemas axilares

Gemas axilares da cultivar 'Valência' foram excisadas de 
plantas obtidas "in vitro" por cultura de nucelos e, do porta-enxerto 'Tri foliata' obtidas de "seedlings" cujas sementes foram colocadas para germi nar em condições assëpticas. Para a obtenção destes "seedlings" foram removidos os integumentos das sementes, a seguir esterilizadas em hipoclori to de södio $1 \%$ e incubadas em meio liquido constituido pelos macro e micro nutrientes do meio "MS".

Cada tubo $(10 \times 2 \mathrm{~cm})$, contendo $10 \mathrm{ml}$ do meio, foi inocula do com uma gema acompanhada de um pequeno segmento do caule (aproximadamen te $0,5 \mathrm{~cm})$.

Utilizou-se o meio básico "MS" adicionado de todas as combi nações possíveis de NAA e BAP nas concentrações de 0,$0 ; 0,1 ; 1,0 ; 5,0$ e $10,0 \mathrm{mg} / 1$ para 'Trifoliata', e 0,$0 ; 0,2 ; 2,0$ e 5,0 mg/l para 'Valência'. Foram usadas 10 repetições para 'Trifoliata'. e 11 para 'Valência', cada uma constituida de 4 tubos de ensaio.

A avaliação, estabelecendo-se o nümero mëdio de brotos com mais de $1 \mathrm{~cm}$ por tubo remanescente, foi realizada após 2 meses de inocula ção, quando os brotos formados foram excisados e transferidos para meio de enraizamento. Nesta mesma ocasião, registrou-se a presença de raízes e ca Ios e estabeleceu-se uma percentagem de frascos que deram alguma resposta, computando-se para tal fim tanto a multiplicação de gemas, como formação de raizes e caios.

\subsubsection{Enraizamento de brotos}

Segmentos do caule com aproximadamente $1 \mathrm{~cm}$ de comprimento, 
apresentando duas gemas em mëdia, obtidos dos experimentos de multiplicação com 'Valencia' e 'Trifoliata' foram inoculados em tubos de ensaio $(20 \times 2$ $\mathrm{cm}$ ) contendo $15 \mathrm{ml}$ do meio "MS", adicionado de um dos seguintes reguladores de crescimento (em mg/l): NAA-0,1;0,5; 1,0 ou 5,$0 ; 1 B A-1,0 ; 2,0 ; 5,0$ ou 10,$0 ;$ NAA- $0,1+I B A-2,0 ;$ NAA-1,0 + IBA-2, 0 ou 5,$0 ;$ NAA- $-5,0+1 B A-2,0 ;$ NAÁ $-5,0+B A P-0,1$ ou $\mathrm{GA}_{3}-5,0$. Foram feitas 10 repetições, cada uma constitui da de 5 tubos.

Os dados foram tomados em percentagem de enraizamento com relação aos tubos remanescentes por ocasião da remosão das plantas para o solo.

\subsection{Cultura de segmentos do fruto de 'Pera'}

Frutos da cultivar 'Pera Bianchi' com aproximadamente $3 \mathrm{~cm}$ de diâmetro foram, apös a esterilização, excisados en condiçces assêpticas. Segmentos de albedo com aproximadamente $0,5 \times 0,5 \times 0,2 \mathrm{~cm}$, de flavedo com $0,5 \times 0,5 \mathrm{~cm}$ e porções com $5-6$ vesículas, foram inoculados em meio "MT" com todas as combinações possíveis de cineiina $(0,0 ; 0,25 ; 0,50 ; 1,0 \mathrm{mg} / 1)$ e 2,4-D $(0,0 ; 5,0 ; 1,0$ e $2,0 \mathrm{mg} / 1)$ em um experimento, bem como cinetina $(0,0 ;$ $0,215$ e $2,15 \mathrm{mg} / 1)$ e IAA $(0,0 ; 0,175 ; 1,75$ e $17,5 \mathrm{mg} / 1)$ em outro. Usaram -se 10 repeíições por tecido em cada experimento, cada uma constituida de um frasco com $10 \mathrm{ml}$ do meio, sendo mantidas 5 no escuro e 5 na luz.

A avaliação foi feita 60 dias apōós a inoculação. As cultu ras foram agrupadas de acordo com o crescimento apresentado e estabelecidas as seguintes classes: 
Exp. 1 - Concentrações de Cin e 2,4-D

\begin{tabular}{rlr} 
Grau $0=$ sem crescimento & \multicolumn{1}{c}{ albedo } & \\
Grau 1 = & calos com: inferior a $0,2 \mathrm{~g}$ & inferior a $0,5 \mathrm{~g}$ \\
Grau 2 = calos com: $\quad 0,2$ a $0,4 \mathrm{~g}$ & 0,4 a $0,6 \mathrm{~g}$ & 1,0 a $1,5 \mathrm{~g}$ \\
Grau 3 = calos com: $\quad 0,0 \mathrm{~g}$ \\
Grau $4=$ calos com: superior a $0,6 \mathrm{~g}$ & superior a $1,5 \mathrm{~g}$
\end{tabular}

Exp. 2 - Concentrações de Cin e IAA

albedo

vesiculas
inferior a $0,1 \mathrm{~g}$
0,1 a $0,5 \mathrm{~g}$
0,5 a $1,0 \mathrm{~g}$
superior a $1,0 \mathrm{~g}$

Foram pesados alguns calos para que as classes pudessem ser estabelecidas e os demais foram classificados por comparação e determinada uma percentagem de calos para cada classe. 
.49 .

\section{RESULTADOS E DISCUSSÃO}

4.7. Cultura de nucelos de 'VaTencia' em diferentes nîveis de auxiná e citocinina

A adição de auxina e citocinina promoveu, de modo geral, uma redução no processo de embriogênese dos nucelos de 'Valência' cul,tivados "in vitro".

Observe-se na Tabela 1 e Figura 1 que, com as culturas ex postas à luz, na ausência de $2,4 \sim D$, não houve diferença significativa para nümero de embriöides por nucelo entre as doses 0,$0 ; 0,25$ e $0,5 \mathrm{mg} / \mathrm{l}$ de cin, pelo teste Tukey-5\%. A adição de $0,5 \mathrm{mg} / 1$ de 2,4-D, na ausência de Cin, reduziu significativamente o número de embriōides e, esta redução foi mais acentuada em presença de Cin. Percebe-se ainda nos valores estabelecidos para média na Tabela 1, que os efeitos prejudiciais da adição de doses bai xas de Cin não são significativos, o contrário do que se verifica com o $2,4-D$.

Quando os nucelos foram mantidos no escuro (Tabela 2), o nú mero de embriôides na ausência de Cin e 2,4-D foi estatisticamente superior aos demais tratamentos. A redução foi drästica já com a adição de $C$ in $\cdots 0,25$ 
TABELA 1. Nümero médio de embriōides obtidos em culturà de nucelos de 'Va lência' en diferentes combinações de Cin e 2,4-D expostos à luz.

\begin{tabular}{|c|c|c|c|c|c|c|c|}
\hline \multirow{2}{*}{$\operatorname{cin}^{2,4-D}$} & \multicolumn{7}{|c|}{$2,4-D(\mathrm{mg} / \mathrm{l})$} \\
\hline & 0,0 & 0,5 & 1, & & 2,0 & & Média \\
\hline 0,0 & 4,6 ab $A$ & 1,8 a $B$ & 0,4 & B & 0,4 & B & 1,80 a \\
\hline$=0,25$ & 4,1 ab $A$ & 0,5 b $B$ & 0,3 & B & 0,0 & B & $1,22 \quad b c$ \\
\hline के 0,50 & 5,6 a $A$ & 0,4 b B & 0,2 & B & 0,0 & B & $1,55 \mathrm{ab}$ \\
\hline$=1,0$ & 2,5 bc $A$ & $0,0 \quad b \quad B$ & 0,0 & $B$ & 0,0 & B & 0,62 \\
\hline $\bar{\omega} 1,5$ & 2,2 & 0,0 & 0,0 & B & 0,0 & B & 0,55 \\
\hline Média & 3,80 & 0,54 & 0,18 & $B$ & 0,08 & B & \\
\hline
\end{tabular}

As médias seguidas da mesma letra (minúscula para niveis de cin e maiúscu la para níveis de 2,4-D) näo diferem entre si pelo teste Tukey-5\%.

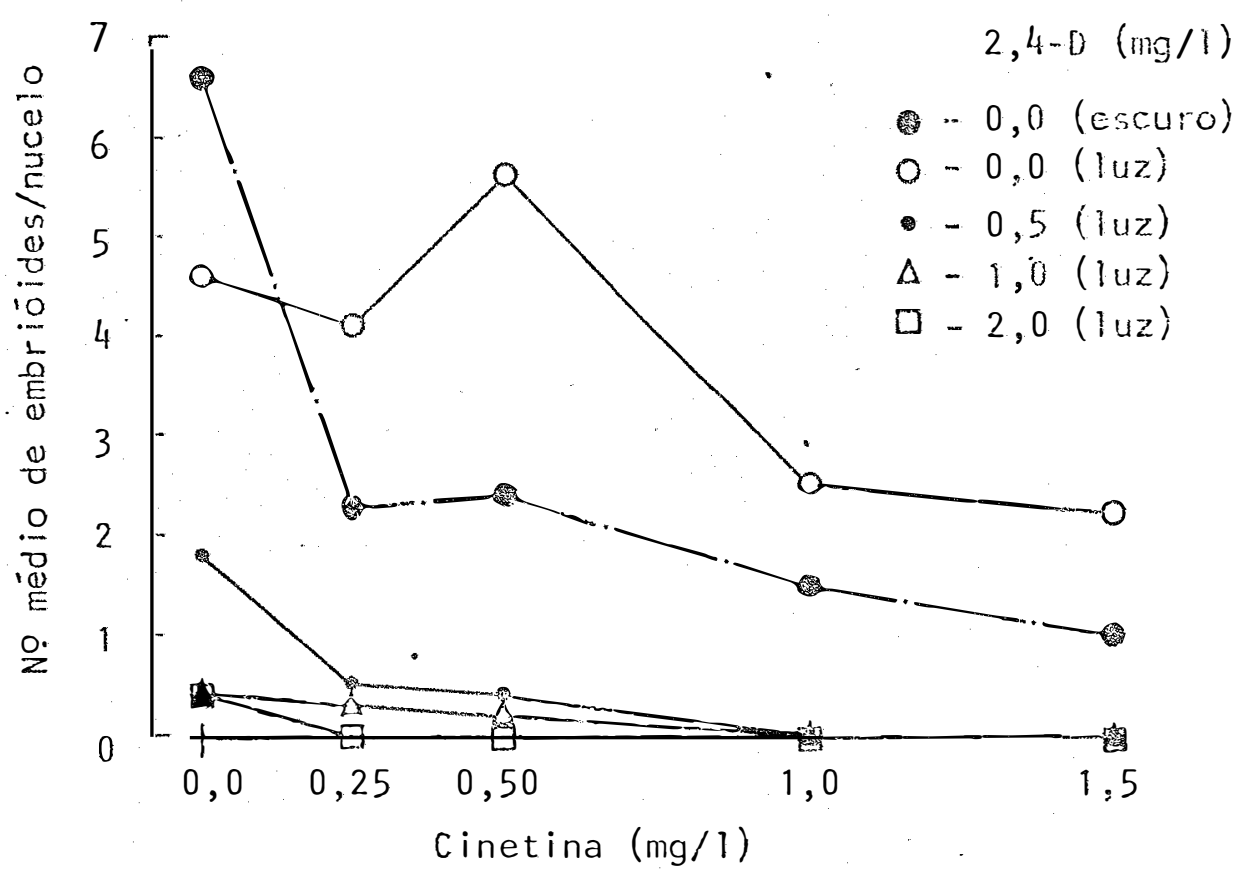

FIGURA 1. Nümero mëdio de embriöides por nucelo nos diferentes nivéis de Cin e 2,4-0. 
TABELA 2. Nümero médio de embriōides obtidos em cultura de nucelos de 'Váa lêncial em diferentes combinações de cin e 2,4.0. mantidos no es curo.

\begin{tabular}{|c|c|c|c|c|c|c|c|c|}
\hline \multirow{2}{*}{\multicolumn{2}{|c|}{$\begin{array}{l}2,4 \cdots D \\
\mathrm{Cin}\end{array}$}} & & \multicolumn{2}{|c|}{, $4-D(\mathrm{mg} / \mathrm{l})$} & 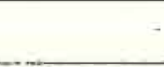 \\
\hline & & \multicolumn{3}{|c|}{0,0} & 0,5 & 1,0 & 2,0 & Média \\
\hline - & 0,0 & 6,6 & & A & $0,0 \quad B$ & $0,0 B$ & $0,0 B$ & 1,65 a \\
\hline ఫ్ & 0,25 & 2,3 & $b$ & A & $0,0 B$ & $0,0 B$ & $0,0 B$ & $0,57 \mathrm{ab}$ \\
\hline E & 0,5 & 2,5 & $b c$ & A & $0,0 \quad B$ & $0,0 B$ & $0,0 \quad B$ & 0,62 ab \\
\hline$\subseteq$ & 1,0 & 1,5 & $c d$ & A & 0,08 & $0,0 \mathrm{~B}$ & $0,0 \mathrm{~B}$ & $0,37 \quad b$ \\
\hline & 1,5 & 1,0 & & A & $0,0 B$ & $0,0 \mathrm{~B}$ & $0,0 \quad \mathrm{~B}$ & $0,25 \quad b$ \\
\hline & Yëdia & $2,8^{\circ}$ & & A & $0,0 B$ & $0,0 B$ & $0,0 B$ & . \\
\hline
\end{tabular}

As médias seguidas da mesma letra (minúscula para niveis de Cin e maiuscu la para niveis de $2,4-D)$ näu diferem entre si pelo teste Tukey- $5 \%$.

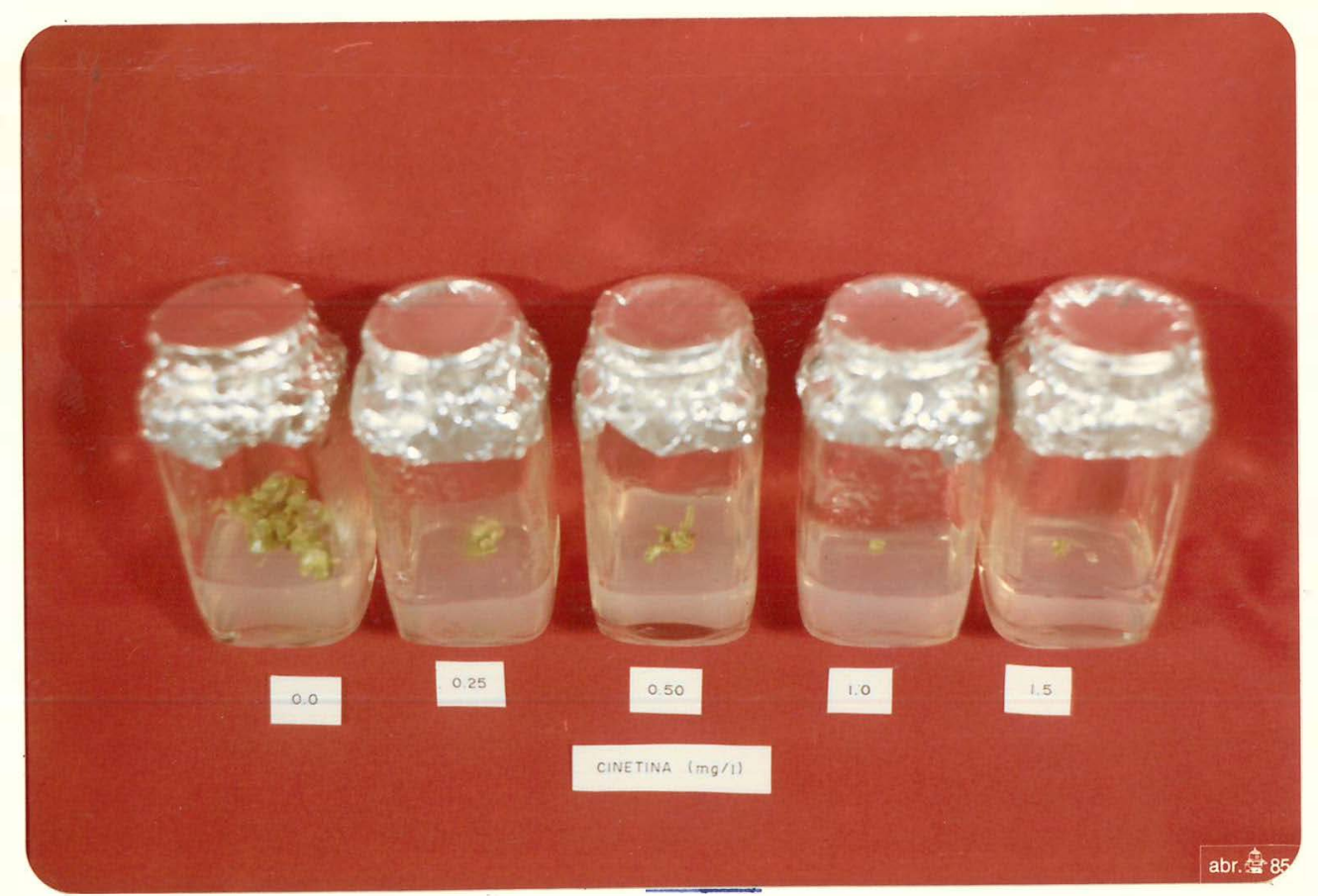

FIGURA 2. Diferenciação de embrióides a partir de nucelos de 'Valência' após 9 semanas de cultivo en diferentes riveis de cinetina. 
mg/l e observoumse uma tendência, inclusive com diferenças significativas, de ampliar a redução nas doses mais elevadas (Figura 2). A adição de qual quer concentração de $2,4-D$ a nucelos mantidos no escuro inibiu totalmente a embriogërese, independentemente da presença de Cin.

Um efeito negativo mais acentuado de $C$ in e 2, 4-D sobre nuce los mantidos no escuro, talvez esteja relacionado ao fato de que os hormô nios em meio de cultura exposto à luz se degradam mais facilmente, anulan do seu efeito inibidor sobre a embriogênese.

Os dois reguladores de crescimento se mostraram detrimentais tambëm ao crescimento dos embriöides formados, uma vez que houve tendência de concentração dos embrióides nas classes më̉io e pequeno com o aumento de seus niveis (Tabela 3 ).

Estes resultados estão de acorcio com afjrmações feitas por ESAN (1973), de que a adição de auxinas e citocininas suprime a embriogê nese em tecido nucelar de citros. Isto leva a crer que estes tecidos pos suem um nivel endögeno destas substâncias e que um incremento neste nível o tornaria além dos limites ótimos necessários para que ocorra embriogênese. Prova disso é que a adição de inibidores da sintese de auxinas e cito cininas estimula fortemente este processo (KOCHEA e SPIEAEL-ROY, 1977).

Os primeiros sinais mostrando diferenciação dos nucelos fo ram observados duas semanas apōs a inoculação, através de um tecido de colo ração verde que foi gradualmente aumentådo de volume e, no final da quarta semana, os embriōides já eran distinguiveis. Após nove semanas de cultura, podia-se notar uma massa de embrióides que ocupava praticamente toda a su 


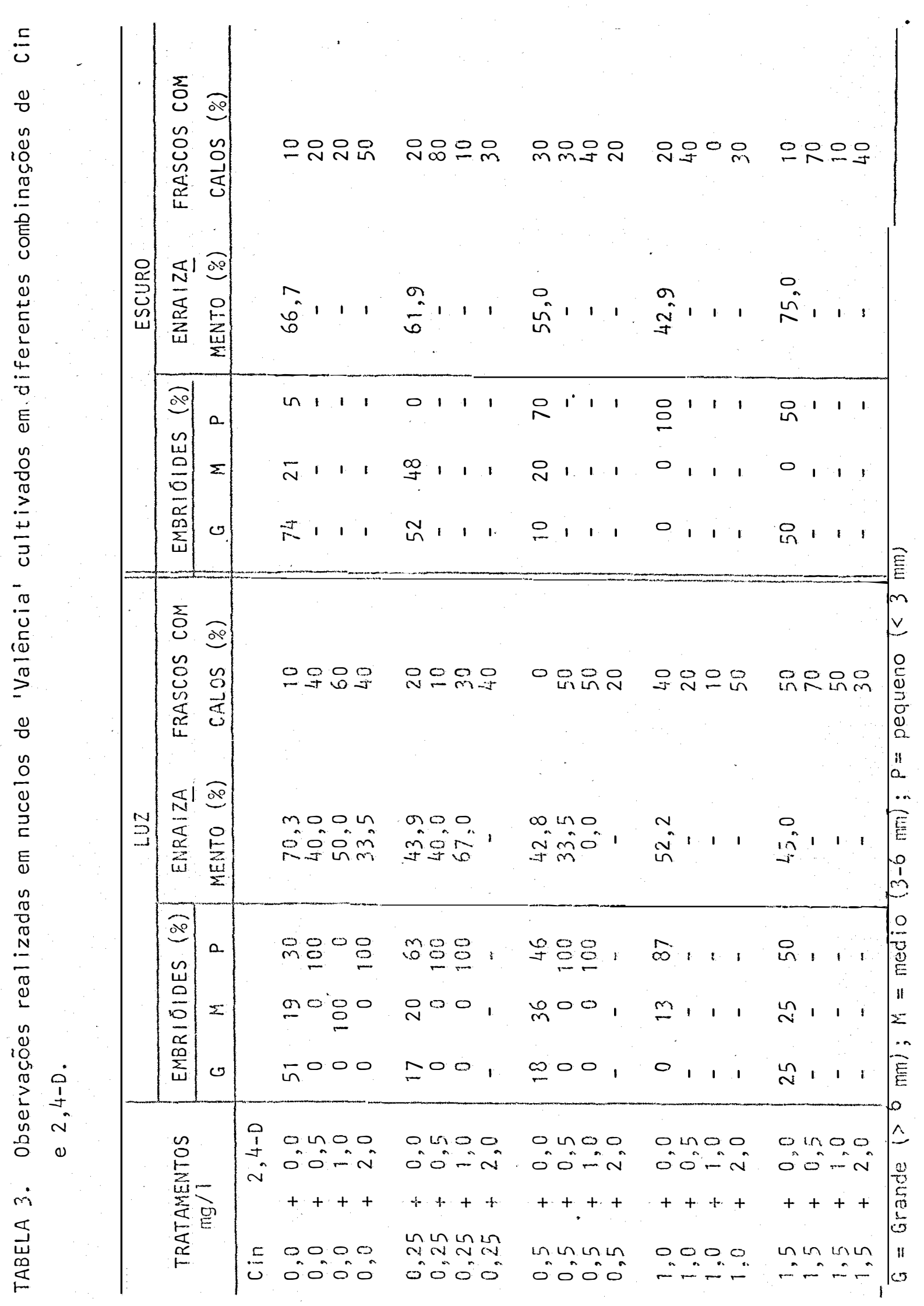


perfície do frasco (Figura 3), ocasião em que foram individualizados para que tivesse continuidade o processo de desenvolvimento. Chegou-se a obser var 12 embrióides oriundos de um único nucelo.

O enraizamento dos embriōides não parece ter sofrido a influ ência da Cin e 2,4-D (Tabela 3), mesmo porque eles foram transferidos para meio sem estes hormönios, onde se daria a diferenciação de raizes.

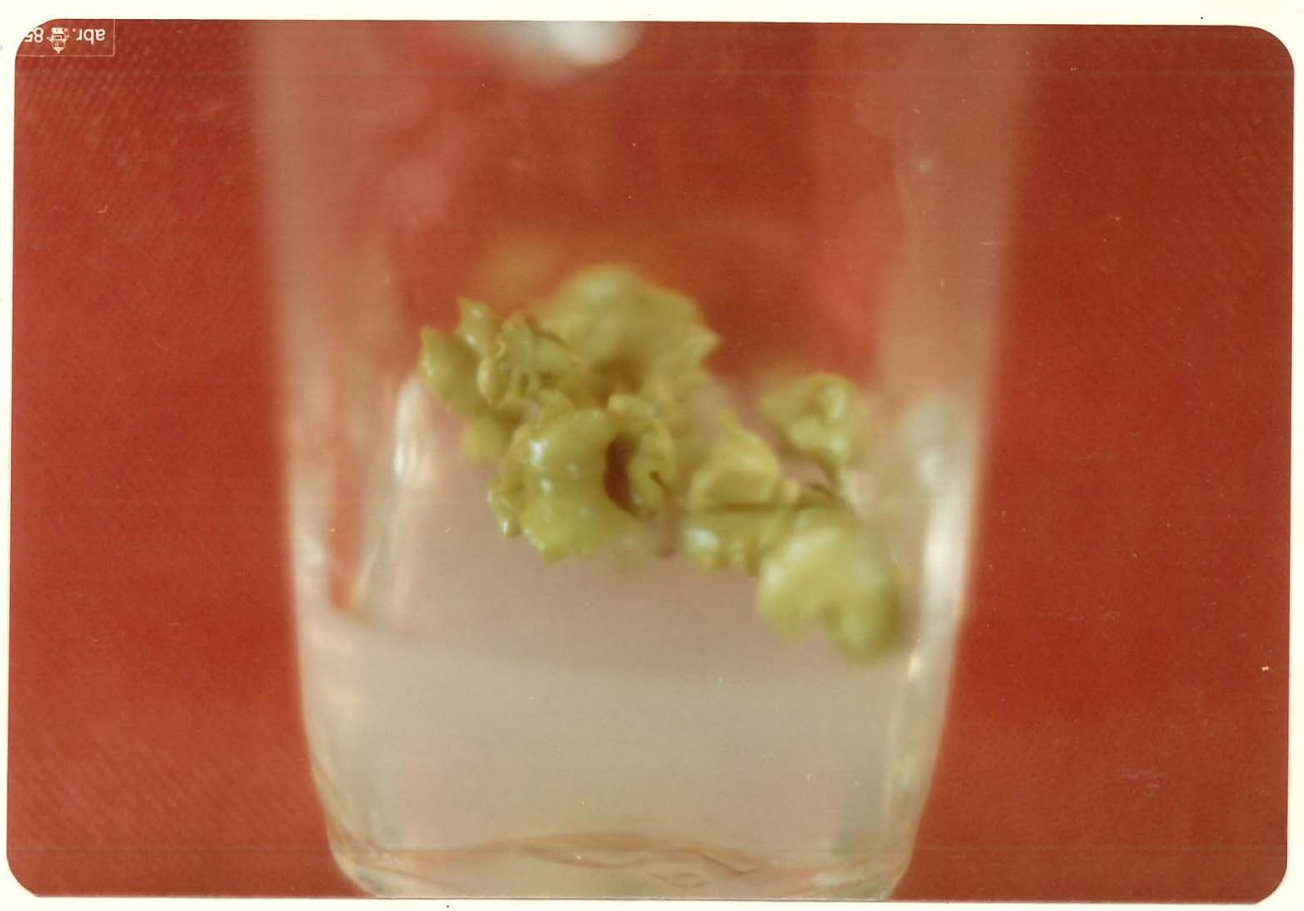

FIGURA 3. Embrióides de 'Valência' diferenciados a partir de nucelos cul tivados "in vitro" na ausência de C.in e 2,4-D.

A presença de calos origirärios de nucelos ou mesmo de em briōides foi evidenciada em praticamente todos os tratamentos, com ou sem a presença de auxina e citocinina, tanto à luz como no escuro (Tabela 3, Figura 4).

Um efeito diferencial tambëm para a produção de calos foi observado de acordo com as condições às quais as culturas foram expostas. 
Em meio desprovido de 2,4-D (Figura 4A), a mäxima percentagem de nucelos com calos foi observada com $0,5 \mathrm{mg} / \mathrm{l}$ de Cin quándo mantidos no escuro, ao passo que os indices maiores para culturas expostas à luz foram observados com concentrações mais elevadas de Cin, uma vez que estes dois reguladores de crescimento induzem a formação de calos, em razão inversa a diferencia ção de embriōides.

Este mesmo tipo de comportamento é visto na presença de $0 ., 5$ $\mathrm{mg} / 1$ de $2,4-D$ e $0,25 \mathrm{mg} / 1$ de $\mathrm{Cin}$ (Figura 4B), onde a presença de calos foi mais evidentè no escuro do que na luz", confirmando justificativa dada para embriogênese em nucelos, de que a exposição do meio à luz causa uma degra dação destes hormônios.

Um exame mais detalhado de alguns calos fêz verificar a pre sença de pseudobulbilhos, alguns dos quais posteriomente se transformaram em embriōides.

Como os embricides formados tem origem unicelular, estes ca los globulares se constituem num excelente material para estudos de indu ção de mutações, atravês. dos quais se pode contornar o problema do quimeris mo, normalmente verificado no tratamento de órgãos multicelulares com agen tes mutagênicos.

Esta mesma constatação havia sido feita por RANGASWAMY (1961), DEIDDA (1973), KOCHBA et ali:i (1972), NAVARRO et alii (1979), per cebendo a presença esporädica de calos glabulares independentemente da in clusão de auxinas e citocininas. 


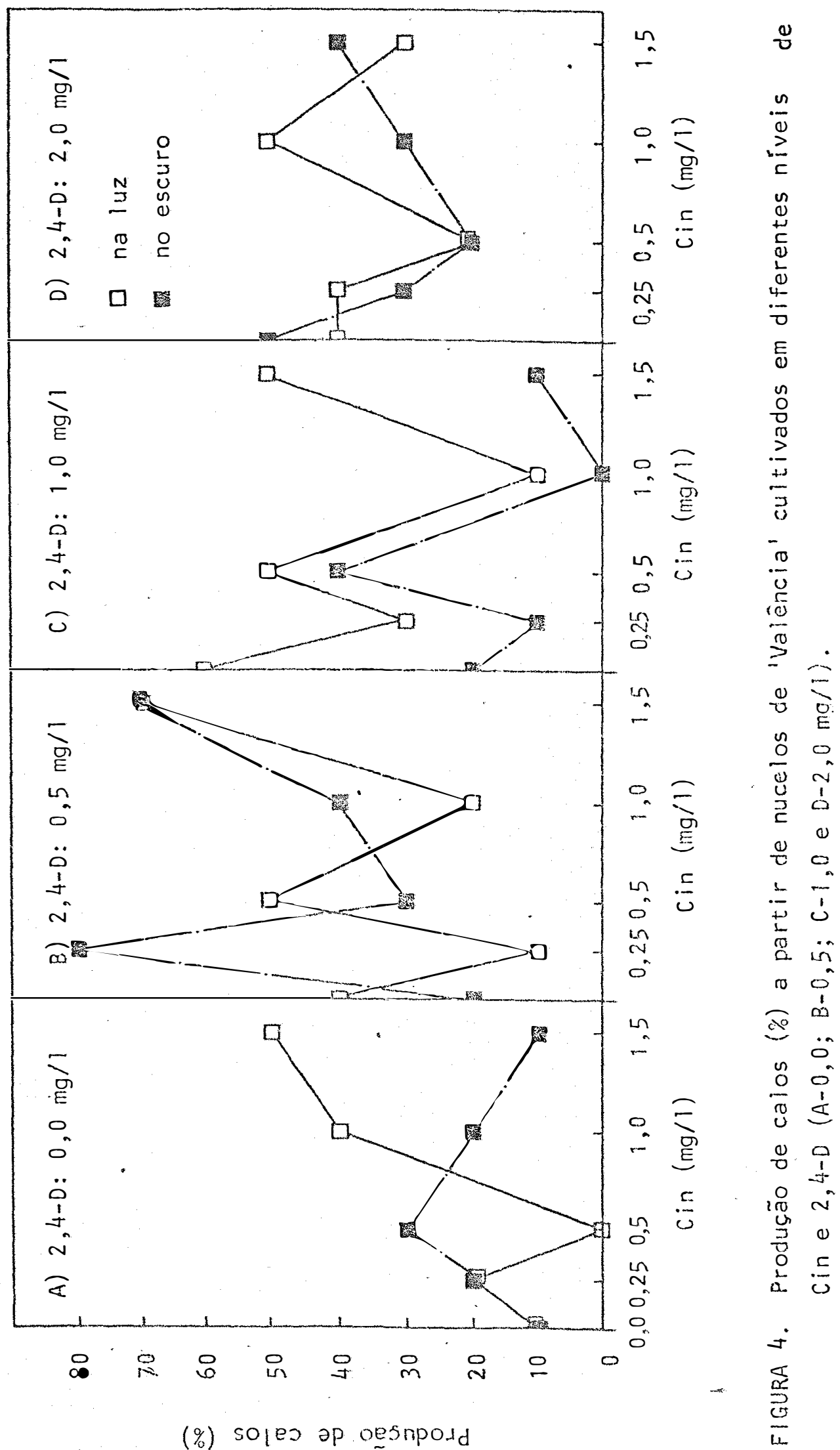




\title{
4.2. Irradiação do tecido nucelar de 'Valência'
}

\begin{abstract}
Quando os nucelos juntamente com o meio de cultura foram trạ tados com raios-gama, em todas as fases houve um decréscimo no número de embrióides por nucelo à medida que se elevaram as doses de radiação. Em. termos mëdios as doses 0,5 e 1,0 kR foram estatisticamente iguais, diferin do de todas as demais pelo teste Tukey a $5 \%$ (Tabela 4 , Figura 5).
\end{abstract}

Esta reduçöo no nümero de embriöides em nucelos tratados por ocasião da inoculação (Tratamento A) e uma semana depois (Tratamento B) foi mais nitida em doses superiores a $2,0 . \mathrm{kR}$. 0 teste Tukey a $5 \%$ não mostrou diferença significativa entre o tratamento $0,5 \mathrm{kP}$ por ocasiäo da inocula ção (Tratamento A) , 0,5; 1,0 e 2,0 kR uma semana apōs a inoculação (Tratamento B) e a testemunha (Tabela 5). O estimulo à diferenciação dos embri öides resultantes de nucelos da cv. 'Shahouti' tratada com 0,5 e $1,0 \mathrm{kR}$, ve rificado por SPIEGEL-ROY e KOCHBA (1973), não foi evidenciado no presente trabalho.

Os efeitos detrimentais clos iratamencos com raios-gama fo ram mais evidentes a medida que a irradiäção se procedeu em data mais dis tante da inoculação, chegandomse ao extremo de uma dose relativamente ba xa como 2,0 kR ser letal. se aplicada três semanas após a inoculação (Figu ra 5 - Trat. D).

De modo geral a irradiação uma semana após a inoculação, in dependentemente de dose, foi a qué forneceu o máior nümero de embrióides, diferindo estatisticamente das demais fases pelo teste de Tukey a 5\% (Tabe 1a 4). 
TABELA 4. Nümero de embrióides obtidos em cultura de nucelos de 'Valência' submetidos a diferentes doses de radiação gama na inoculação ( $A$ ), uma (B), duas (C) e três semanas depois (D).

\begin{tabular}{|c|c|c|c|c|c|c|}
\hline $\begin{array}{r}\text { FASE } \\
\text { DOSE }(k R)\end{array}$ & A & B & C & & $D$ & MEDIA \\
\hline 0,5 & 3,6 a $\cdots A$ & $4,7 a b$ & $1,8 \mathrm{a}$ & B & $1,3, a \quad B$ & 2,8 a \\
\hline 1,0 & 2,8 ab $\quad B$ & 5,2 a & 1,5 a & B & 0,5 ab $c$ & 2,5 a \\
\hline 2,0 & 3,3 ab $A$ & 3,4 bc $A$ & $0,7 \mathrm{ab}$ & B & $0,0 \quad b \quad B$ & $1,8 \quad b$ \\
\hline 4,0 & 1,7 bc $A$ & $\operatorname{cd} A$ & $0,3 \quad b$ & B & $0,0 \quad b \quad B$ & 1,0 \\
\hline 8,0 & $\operatorname{cd} A$ & $\operatorname{de} A$ & $0,1 \quad b$ & $\mathrm{BC}$ & 0,0 b $c$ & 0,6 \\
\hline 12,0 & 0,0 & 0,4 & $0,0 \quad b$ & & $0,0 \quad b$ & 0,1 \\
\hline Média & 2,1 & 2,8 & 0,7 & C & 0,3 & \\
\hline
\end{tabular}

As mēdias seguidas da mesma letra (minúscula para doses e maiüscula para fases) não diferem entre si pelo teste Tukey-5\%.

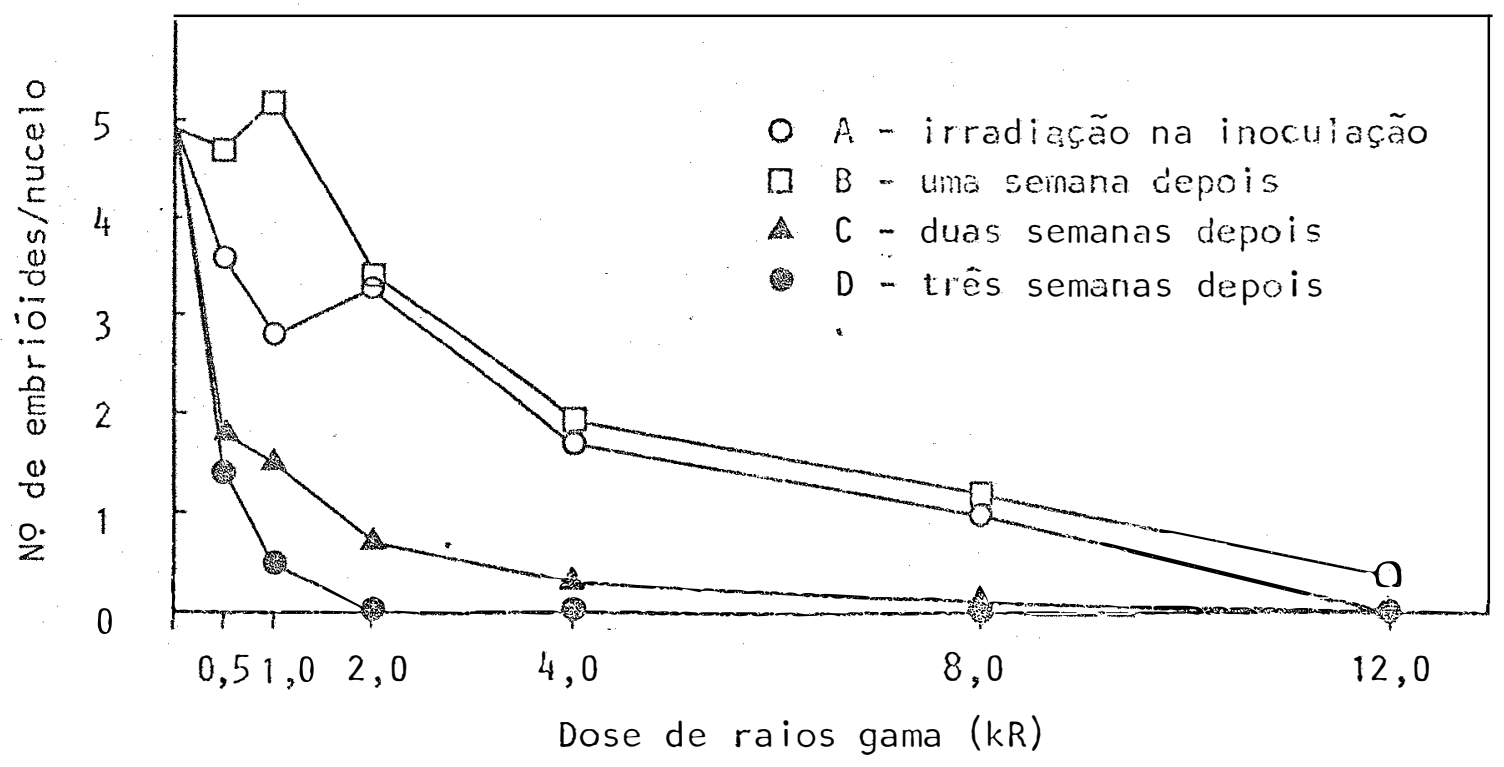

FIGURA 5. Nümero de embrióides obtidos em cultura de nucelos submet́idos a diferentes doses de radiação gama e em diferentes fases. 


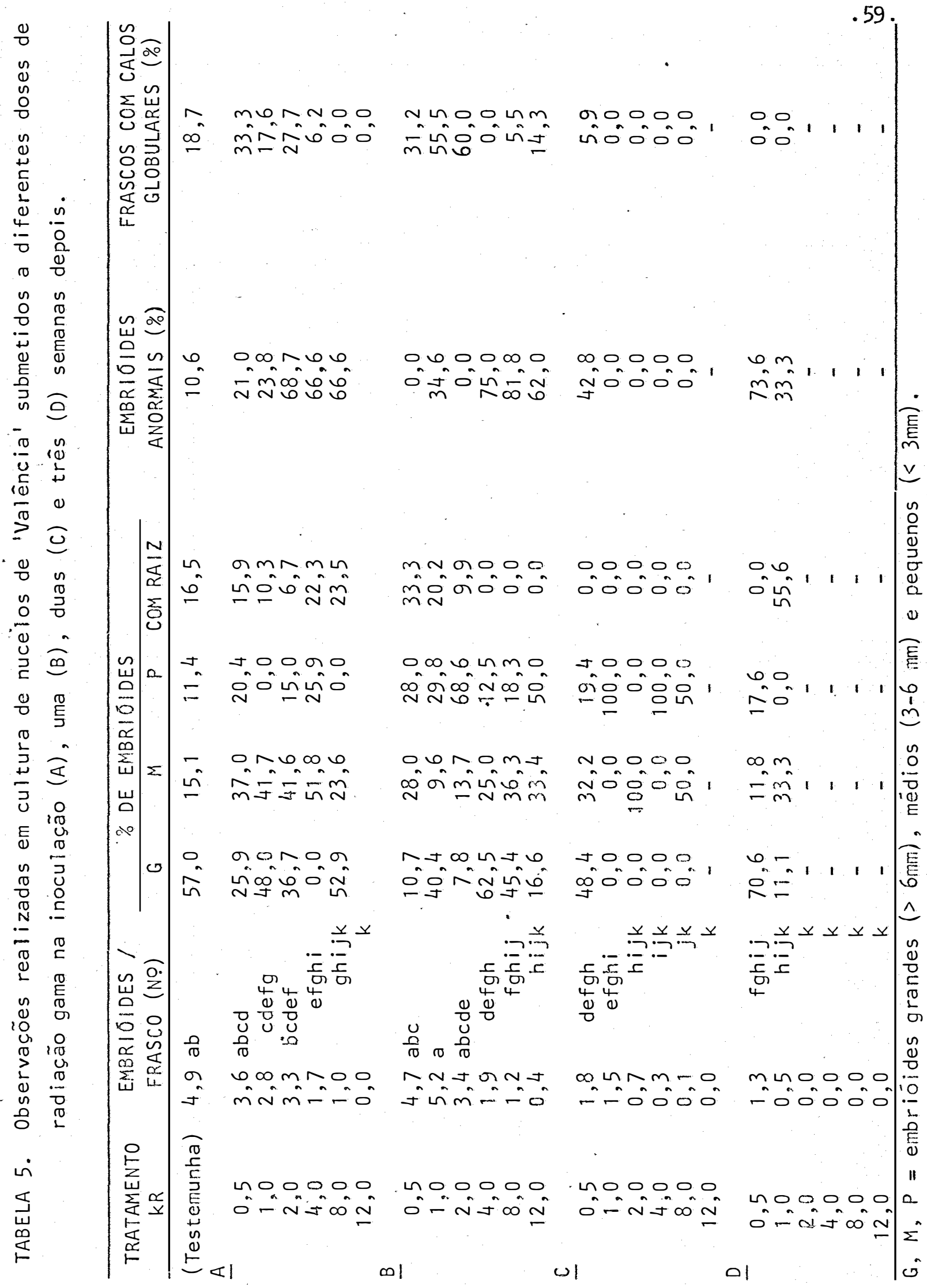


0 nümero de embriōides obtidos foi baixo, caracterizando o nucelo como um tecido cujas células são extremamente sensitivas à radiação. Apesar disto e da disponibilidade de nucelos ter uma limitação sazonal, além da dificuldade da sua extração, a aplicação de tratamentos mutagênicos a estes tecidos nucelares se constitui numa alternativa de melhoramento ge nético, considerando a origem unicelular doș embrióides, evidenciada em es tudos de microscopia eletrônica levados a efeito por BUTTON et alii (1974).

Observe-se na Tabela 6 e Figura 6 que a irradiação apenás dos nucelos (Trat. F) mostrou um efeito similar àquele fornecido pela irra diação do nucelo e do meio por ocasião da inoculação (Trat. G). Por outro lado observou-se que com a irradiação apenas do meio de cultura (Trat. E) houve um decréscimo no nümero de embrióides diferenciados nas doses mais baixas, o qual foi gradualmente se elevando, atingindo valor superior à tes temunha na dose de 12,0 kR, embora não diferindo significativamente das do ses 8,0 e 4,0 kR.

Sob o ponto de vista estatístico os tratamentos do meio nas doses de 4,0;8,0 e $12,0 \mathrm{kR}$, do nucelo com $1,0 \mathrm{kR}$, do nucelo e do meio com 0,5 e 2,0 kR não diferiram da testemunha pelo teste Tukey a 5\% (Tabela 7).

Este estímulo à embriogênese fornecido pela irradiação do meio de cultura tem sido atribuido a uma redução dos niveis de auxinalCHOU REY et alii, 1973) ou de outras substâncias inibidoras do processo embrio gênico. Auxinas e citocininas inibem a embriogênese de nucelos e calos nu

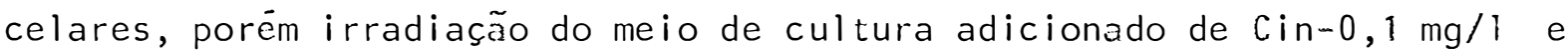
IAA-0,1 mg/I (SPIEGEL-ROY e KOCHBA, 1980) estimulou notavelmente a diferen 
.61

TABELA 6. Número de embrióides obtidos em cultura de nucelos de 'Valência' apōs irradiação (em diferentes doses) do meio (E), do nucelo(F) ou do meio e do nucelo $(G)$.

\begin{tabular}{|c|c|c|c|c|}
\hline $\begin{array}{r}\text { MAT. } \\
\text { DOSE (kR) }\end{array}$ & $E$ & $F$ & G & MEEDIA \\
\hline 0,5 & $2,1 \quad b$ & $2,8 \mathrm{a}$ & 3,6 a & 2,8 a \\
\hline 1,0 & $3,1 \quad b$ & 3,3 a & $2 ; 8$ a & 3,1 a \\
\hline 2,0 & $2,7 \quad b$ & 3,0 a & 3,3 a & 3,0 a \\
\hline 4,0 & 3,7 ab $A$ & 1,8 a $B$ & 1,7 ab $B$ & $2,4 a b$ \\
\hline 8,0 & 3,9 ab $A$ & 1,9 a $B$ & $1,0 \quad b \quad B$ & $2,3 a b$ \\
\hline 12,0 & $5,9: a \quad A$ & 0,3 b $B$ & $0,0 \quad b \quad B$ & $2,2 \quad b$ \\
\hline Mëdia & 3,6 & 2,2 & 2,1 & \\
\hline
\end{tabular}

As médias seguidas da mesma letra (minúscula dose e maiúscula para material tratado) não diferem entre si pelo teste Tukey $-5 \%$.

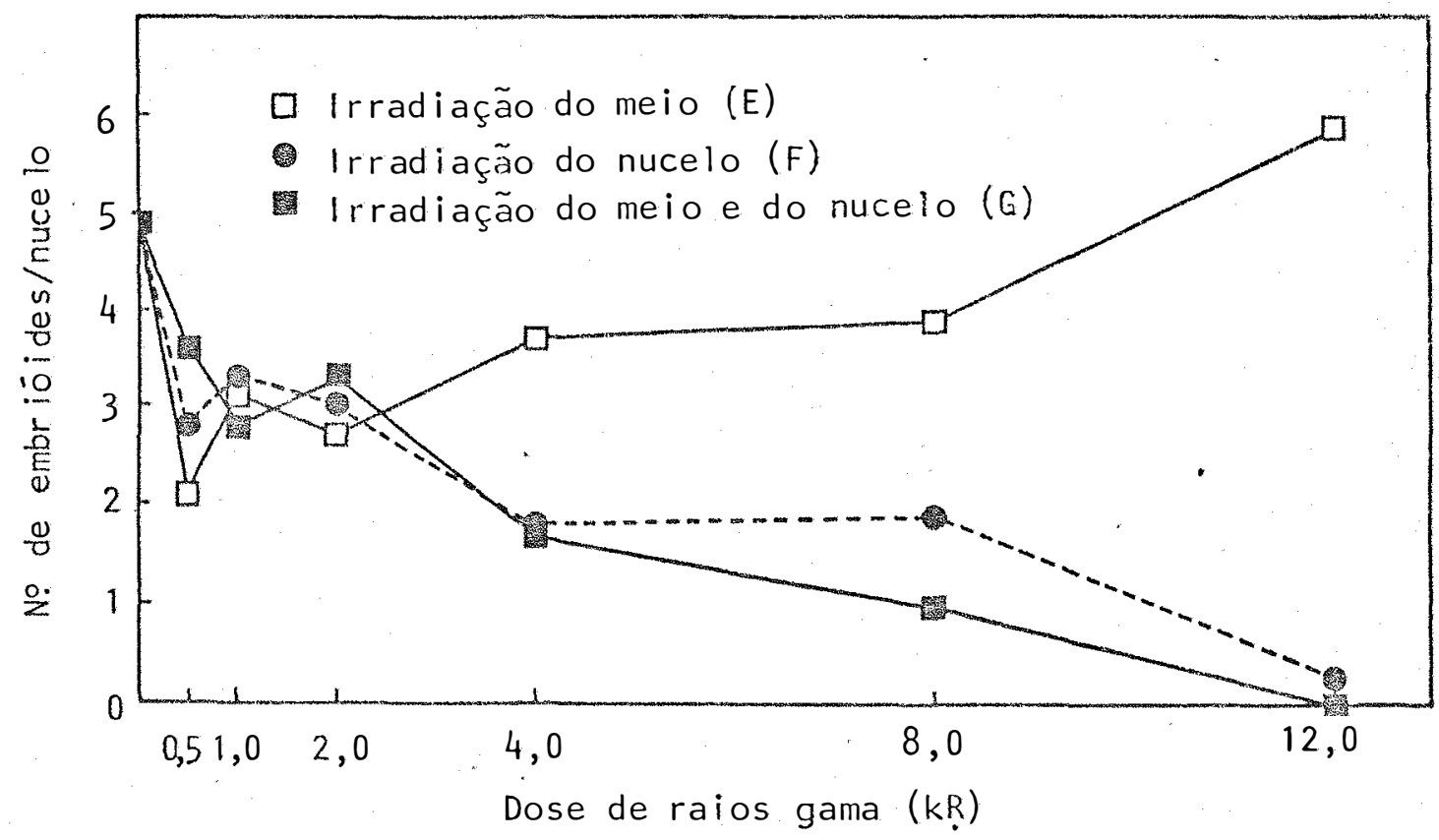

FIGURA 6. Nümero de embriōides obtidos de nucelos apōs irradiação (em di ferentes fases) do meio (E), do nucelo $(F)$ ou do nucelo e do meio $(G)$. 


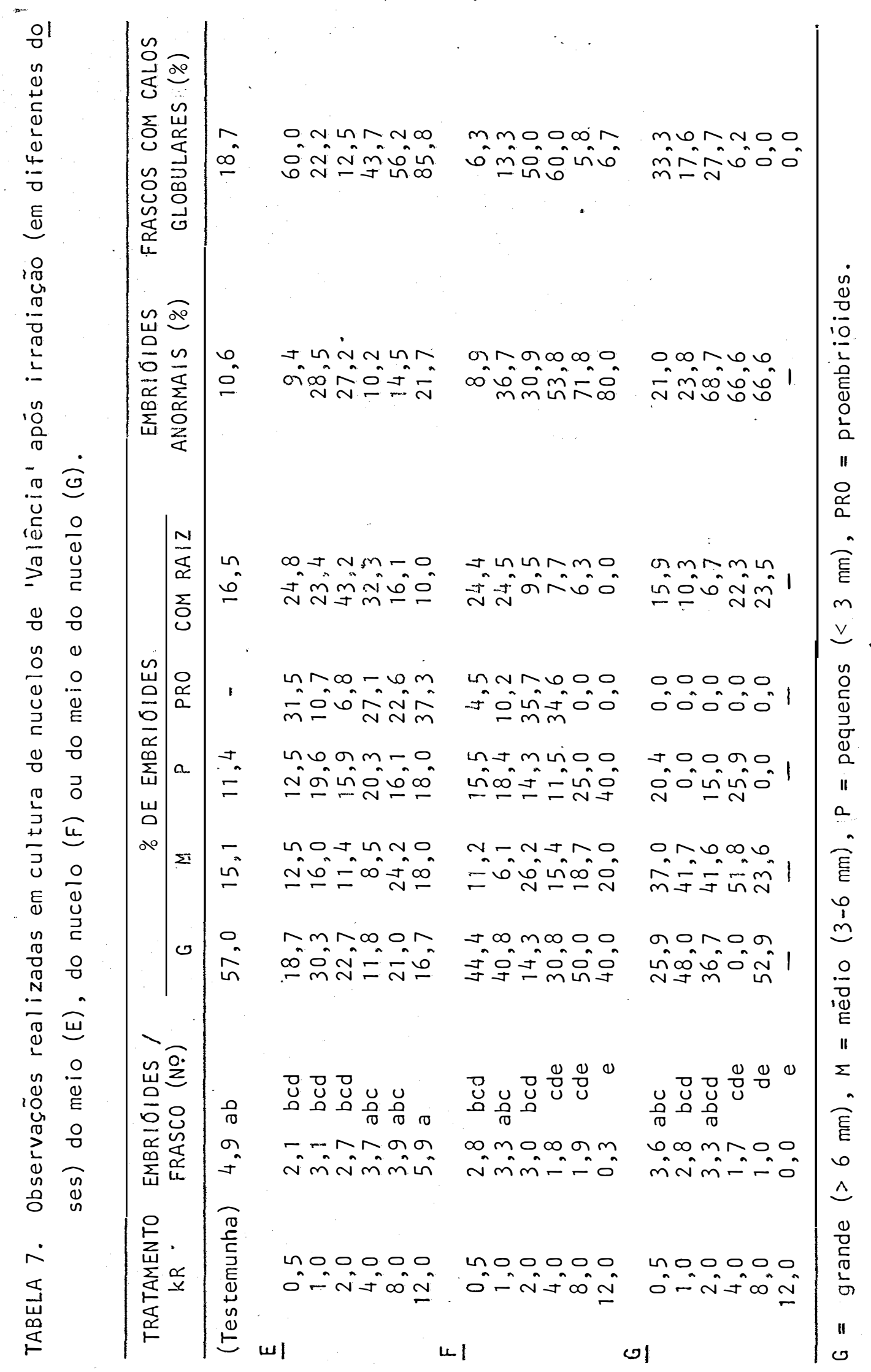

.62 
ciação de embrióides. Provavelmente alguma substância componente do meio estaria comprometendo a embriogênese e, com:a irradiação, estas substâncias seriam reduzidas a um nivel mais próximo do ótimo para diferenciação de em briōides.

0 incremento na formação de calos constituidos por corpúscu los globulares em meio tratado com altas doses de radiação, como pode ser visto na Tabela 6 e Figura 7, fornece outra explicação para o aumento do nümero de embrióides neste mesmo meío. Estes calos são altamente embriogê nicos (Figura 8) e poderiam ter sido os responsáveis pelo número adicional de embrióides diferenciados. A irradiação apenas do nucelo (Tabela 7, Trat. F) com doses de 2,0 e 4,0 kR estimulou fortemente a formação deste tipo de calo (Figura 7). Nos demais tratamentos, a presença destes calos näo foi tão significativa, a não ser nas doses de 1,0 e 2,0 kR, aplicadas ao nuce lo uma semana após a inoculação (Tabela 5 - Trat. B), onde também foi evi denciado o número máxim• de embrióides por nucelo.

Tanto os nucelos como os calos nucelares se constituem, jun tamente com protoplastos, suspensão celular e micrósporos, em materiais ex tremamente üteis no melhoramento por indução de mutações, utilizando as técnicas de cultura de tecidos e células. Isto significaria também uma pré - seleção em uma escala sem precedente, e uma apreciável contribuição à va riabilidade genëtica.

0 desenvolvimento e aperfeiçoamento dos métodos pode, de fä to, dirigir uma maior parte dos esforços com melhoramento, no futuro, em direção à mutâgênese. 
.64.

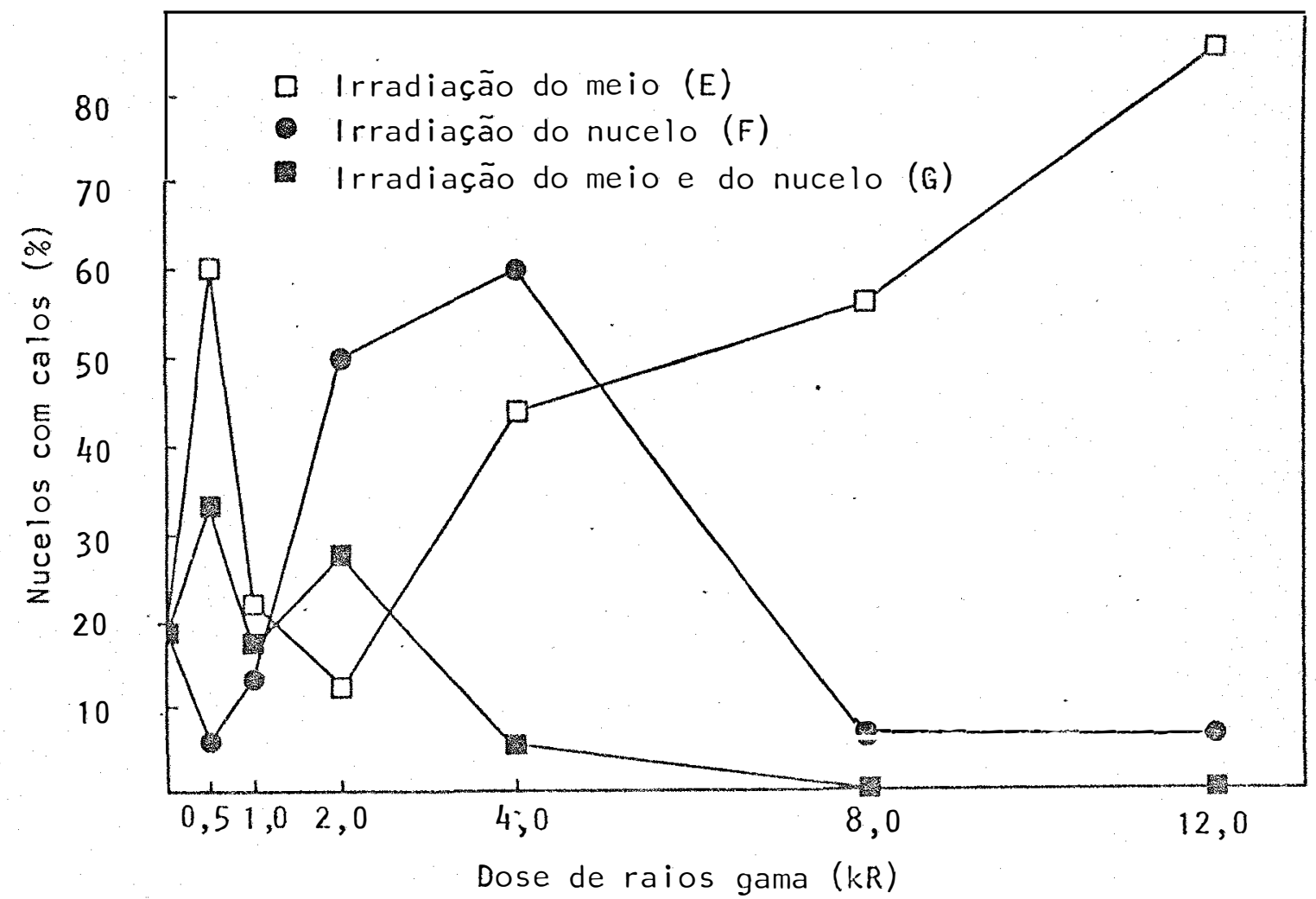

FIGURA 7. Nucelos que produziram calos (\%) após irradiação (em diferentes doses) do meio (E), do nucelo (F) ou do meio e do nucelo (G).

Observou-se um elevado indice de anormalidade nos embriōides oriundos de nucelos irradiados (Tabelas 5 e 7 ), principalmente com doses mais elevadas. Embriöides fasciados, com muitos cotiledones unidos entre si e embriöides com cotiledones de tamanho diferente foram as principais de formações encontradas. Anomalias similares tem sido reportadas por vários autores (DEIDDA, 1973; JUAREZ et alii, 1976; STARRANTINO et alii, 1978), po rëm, em menor extensão, mesmo sem o uso de agêntes mutagênicos.

Plantas obtidas por cultura de nucelos, de modo geral, apre sentaram-se normais sob o ponto de vista morfolögico. Apenas eventuais bi furcações do caule ou ligeiras modificações na forma da folha foram eviden 


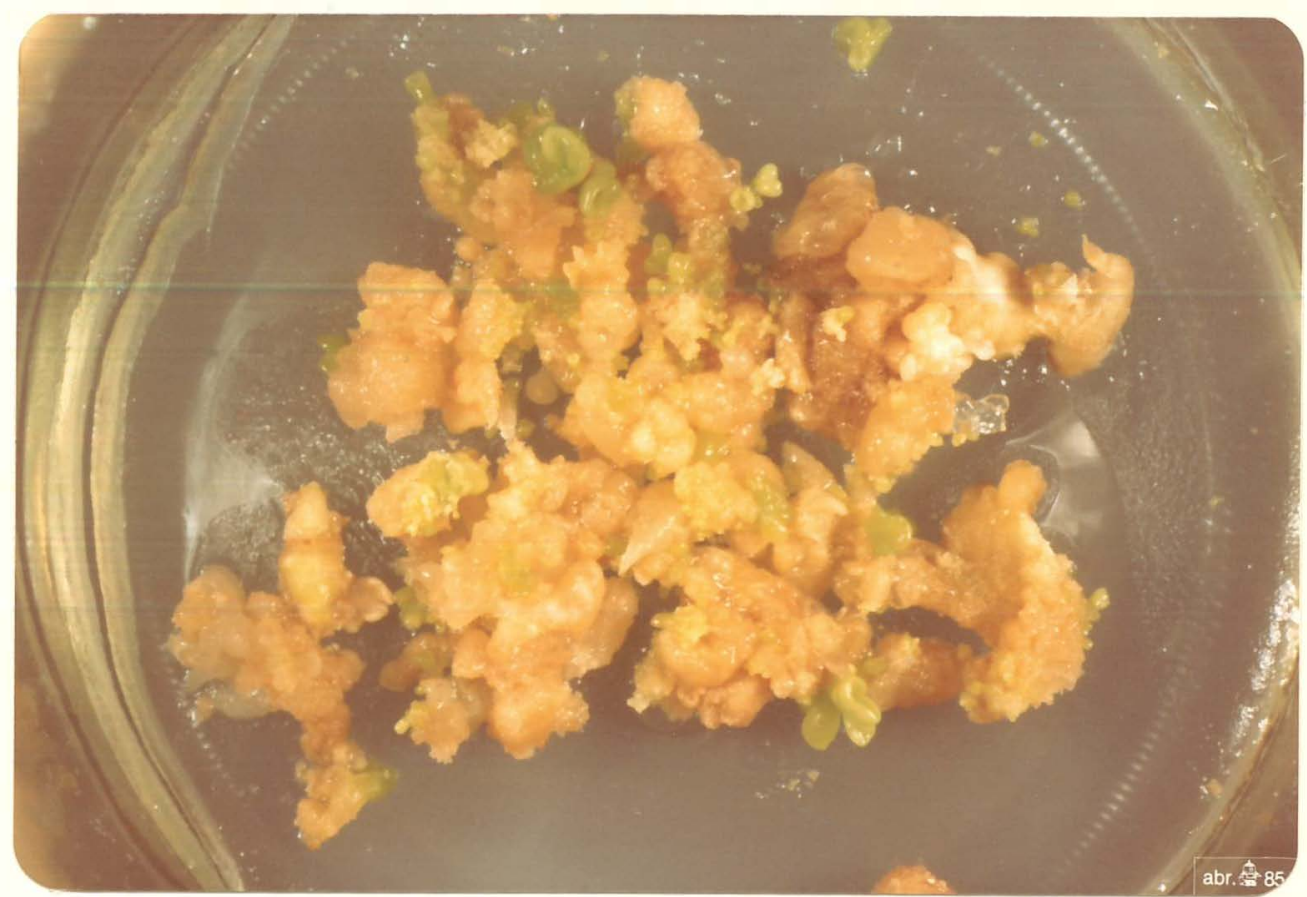

FIGURA, 8. Calos globulares obtidos de nucelos de 'Valéncia' cultivados em meio irradiado, mostrando elevado potencial embriogénico.

ciadas. Fato semelhante foi observado por NAVARRO et alii (1979), onde plantas oriundas de embrióides anormais apresentaram-se sem qualquer alte ração externa. Por outro lado, dUAREZ et alii (1976) e STARRANTINO et alii (1978) relataram a presença de caracteres anormais em $20 \%$ das plantas nuce lares, principalmente aqueles relacionados com peciolos e forma de folha.

Esta aparente normalidade de plantas deve estar relacionada ao fato de que a grande maioria dos embrióides deformados não tem condições de regenerar uma planta completá. Sendo assim, plântulas seriam originā rias quase exclusivamente de embriōides normais, o que reduz em muito o nú mero delas (Tabelas 8 e 9) e, pode levar à falsa impressão de que embriói des deformados originam plantas normais. Isto pode ser confirmado obser vando-se que, em muitos tratamentos com radiação, os embrióides obtidos 
.66

TABELA 8. Desenvolvimento de embrióides (\%) individualizados oriundos de nucelos submetidos a diferentes doses de radiação na inoculação (A), uma (B), duas (C) ou três (D) semanas depois.

\begin{tabular}{|c|c|c|c|c|c|}
\hline \multicolumn{2}{|l|}{ TRATAMENTO } & \multicolumn{3}{|c|}{ DIFERENCI AC,ÁO DE (\%) } & \multirow[b]{2}{*}{ PROEMBRIOIDES } \\
\hline $\mathrm{kR}$ & RAIZ & PARTE AEREA & PLÃNTULA & EMBRIÓIDES & \\
\hline Tes temunha & 16,0 & 11,4 & 63,0 & 8,0 & 12,0 \\
\hline \multicolumn{6}{|l|}{ A } \\
\hline 0,5 & 55,2 & 17,2 & 10,3 & 0,0 & 6,9 \\
\hline 1,0 & 15,8 & 26,3 & 21,0 & 21,0 & 10,0 \\
\hline 2,0 & 6,7 & 30,0 & 30,0 & 6,7 & 0,0 \\
\hline 4,0 & 0,0 & 0,0 & 50,0 & 0,0 & 0,0 \\
\hline 8,0 & 0,0 & 0,0 & 0,0 & 0,0 & 0,0 \\
\hline 12,0 & - & - & - & - & - \\
\hline \multicolumn{6}{|l|}{ B } \\
\hline 0,5 & 10,5 & 10,5 & 42,0 & 5,3 & 15,8 \\
\hline 1,0 & 5,7 & 40,0 & 34,0 & 2,8 & 0,0 \\
\hline 2,0 & 0,0 & 50,0 & 16,7 & 0,0 & 8,3 \\
\hline 4,0 & 6,2 & 18,7 & 43,7 & 0,0 & 0,0 \\
\hline 8,0 & 10,0 & 10,0 & 50,0 & 0,0 & 0,0 \\
\hline 12,0 & 0,0 & 0,0 & 33,3 & 0,0 & 0,0 \\
\hline \multicolumn{6}{|l|}{$\underline{c}$} \\
\hline 0,5 & 0,0 & 33,3 & 16,7 & 0,0 & 0,0 \\
\hline 1,0 & 0,0 & 0,0 & 20,0 & 20,0 & 80,0 \\
\hline 2,0 & 0,0 & 0,0 & 0,0 & 0,0 & 0,0 \\
\hline 4,0 & 0,0 & 0,0 & 0,0 & 0,0 & 0,0 \\
\hline 8,0 & 0,0 & 0,0 & 0,0 & 0,0 & 0,0 \\
\hline 12,0 & 0,0 & 0,0 & 0,0 & 0,0 & 0,0 \\
\hline \multicolumn{6}{|l|}{$\underline{D}$} \\
\hline 0,5 & 10,5 & 31,6 & 18,6 & 15,8 & 0,0 \\
\hline 1,0 & 0,0 & 66,7 & 0,0 & 0,0 & 0,0 \\
\hline 2,0 & 0,0 & 0,0 & 0,0 & 0,0 & 0,0 \\
\hline 4,0 & 0,0 & 0,0 & 0,0 & 0,0 & 0,0 \\
\hline 8,0 & 0,0 & 0,0 & 0,0 & 0,0 & 0,0 \\
\hline 12,0 & 0,0 & 0,0 & 0,0 & 0,0 & 0,0 \\
\hline
\end{tabular}


TABELA 9. Desenvolvimento de embriōides individualizados obtidos de nuce los após irradiação (em diferentes doses) do meio (E), do nuce lo (F) ou do nucelo e do meio (G).

\begin{tabular}{|c|c|c|c|c|c|}
\hline \multirow{2}{*}{$\begin{array}{c}\text { TRATAMENTO } \\
\text { kR }\end{array}$} & \multicolumn{5}{|c|}{ DIFERENC IAÇ̃̃OO DE (\%) } \\
\hline & RAIZ & PARTE AEREA & PLANTULA & EMBRIŌIDES & PROEMBRIOIDES \\
\hline Testemunha & $16 ; 0$ & 11,4 & 63,0 & 8,0 & 12,0 \\
\hline$\underline{E}$ & \multicolumn{5}{|c|}{ - } \\
\hline 0,5 & 14,3 & 28,6 & 14,3 & 7,2 & 28,5 \\
\hline 1,0 & 8,1 & 13,5 & 37,8 & 5,4 & 8,1 \\
\hline 2,0 & 4,5 & 9,1 & 45,4 & 18,2 & 18,2 \\
\hline 4,0 & $37 ; 5$ & 0,0 & 8,3 & 0,0 & 25,0 \\
\hline 8,0 & 5,3 & 0,0 & 44,5 & 15,8 & 5,3 \\
\hline 12,0 & 14,7 & 2,9 & 44,1 & 55,9 & 14,7 \\
\hline \multicolumn{6}{|l|}{$\underline{F}$} \\
\hline 0,5 & 21,4 & 7,1 & 14,3 & 0,0 & 0,0 \\
\hline 1,0 & 6,3 & 6,2 & 53,1 & 28,1 & 12,5 \\
\hline 2,0 & 0,0 & 0,0 & 0,0 & 0,0 & 0,0 \\
\hline 4,0 & 44,4 & 0,0 & 44,4 & 0,0 & 33,3 \\
\hline 8,0 & 19,6 & 5,4 & 34,0 & 0,0 & 14,3 \\
\hline 12,0 & 0,0 & 0,0 & 0,0 & 0,0 & 0,0 \\
\hline \multicolumn{6}{|l|}{$G$} \\
\hline 0,5 & 55,2 & 17,2 & 10,3 & 0,0 & 6,9 \\
\hline 1,0 & 15,8 & 26,3 & 21,0 & 21,0 & 10,5 \\
\hline 2,0 & 6,7 & 30,0 & 30,0 & 6,7 & 0,0 \\
\hline 4,0 & 0,0 & 0,0 & 50,0 & 0,0 & 0,0 \\
\hline 8,0 & 0,0 & 0,0 & 0,0 & 0,0 & 0,0 \\
\hline 12,0 & & & & & \\
\hline
\end{tabular}


quando individualizados, apresentam um índice de formação apenas de raiz ou de parte aérea muito superior à testemunha (Tabelas 8 e 9).

Ainda nas Tabelas 8 e 9 pode-se perceber que os embrióides podem originar novos embrióides e proembrióides, se constituindo também em uma possibilidade de multiplicação de embrióides, desde que the sejam for necidas condições adequadas. Observações similares tem sido feitas por ESAN (1973) caracterizando esta proliferação como um processo de gemação.

4.3. Cultura de óvutos abortivos da cv. 'Pera' em diferentes fases

Como se observa na Tabèla 10, o número de embrióides obtidos com a cultivar 'Pera' em cultura de óvulos abortivos, é bem inferior aque le observado em cultura de nucelos de 'Valêricia' ńos mesmos meio e estādio de desenvolvimento. No estádio $E_{6}$ da $\mathrm{cv}$. 'Pera' que corresponde à idade aproximada de 12 semanas, fase normalmente utilizada para extração de nuce los de 'Valência' obteve-se um riúmero médio de 1,0 embriōide por óvulo, quando com a cv. 'Valência' foram obtidos até 6,6 embrióides por nucelo. Outra observação é que com a c.v. 'Pera' nenhum óvulo diferenciou embriōi des quando mantido no escuro, e sim, apenas calos em até $100 \%$ dos explantes, contrariando observações feitas com 'Valência' onde o número de embri óides foi maior no escuro do que à luz.

Estes resultados mostram a exigência diferencial com relação às condições de cultura para as diferentes cultivares, corroborando cita ções de outros autores (BITTERS et alii, 1970; KOCHBA et alii, 1972; NAVAR $R O$ et alii, 1979), que identificaram variações significativas na percenta gem de sucesso entre cultivares. 
TABELA 10. Embriōides (Nọ) e calos (\%) obtidos a partir de cultura de óvu los abortivos de 'Pera' em diferentes fases de desenvolvimento.

\begin{tabular}{|c|c|c|c|c|}
\hline \multirow[t]{2}{*}{ TRATAMENTO } & \multicolumn{2}{|c|}{$\begin{array}{l}\text { NO MEDIO DE EMBRIOIDES } \\
\text { POR FRASCO } \\
\end{array}$} & \multicolumn{2}{|c|}{$\begin{array}{l}\% \text { DE FRASCOS COM } \\
\text { CALOS }\end{array}$} \\
\hline & LUZ & ESCURO & LUZ & ESCURO \\
\hline$E_{1}$ - Botão floral & 0,0 & 0,0 & 0,0 & 0 \\
\hline $\mathrm{E}_{2}$ - Frutos com $0,95 \times 0,77 \mathrm{cr.1}$ & 0,4 & 0,0 & 0,0 & 30 \\
\hline$E_{3}-$ Frutos com $1,25 \times 1,02 \mathrm{~cm}$ & 0,7 & 0,0 & 0,0 & 60 \\
\hline$E_{4}$ - Frutos com $1,62 \times 1,60 \mathrm{~cm}$ & 1,0 & 0,0 & 0,0 & 100 \\
\hline$E_{5}-$ Frutos com $2,55 \times 2,29 \mathrm{~cm}$ & 1,8 & 0,0 & 0,0 & 80 \\
\hline $\mathrm{E}_{6}-$ Frutos com $3,38 \times 3,02 \mathrm{~cm}$ & 1,0 & 0,0 & 0,0 & 80 \\
\hline
\end{tabular}

Os calos obtidos eram duros (não friāveis), coloração amare lo creme e mostravam crescimento apenas no sintido lateral. Foram observa dos, esporadicamente, calos altamente embriogênicos (Figura 9).

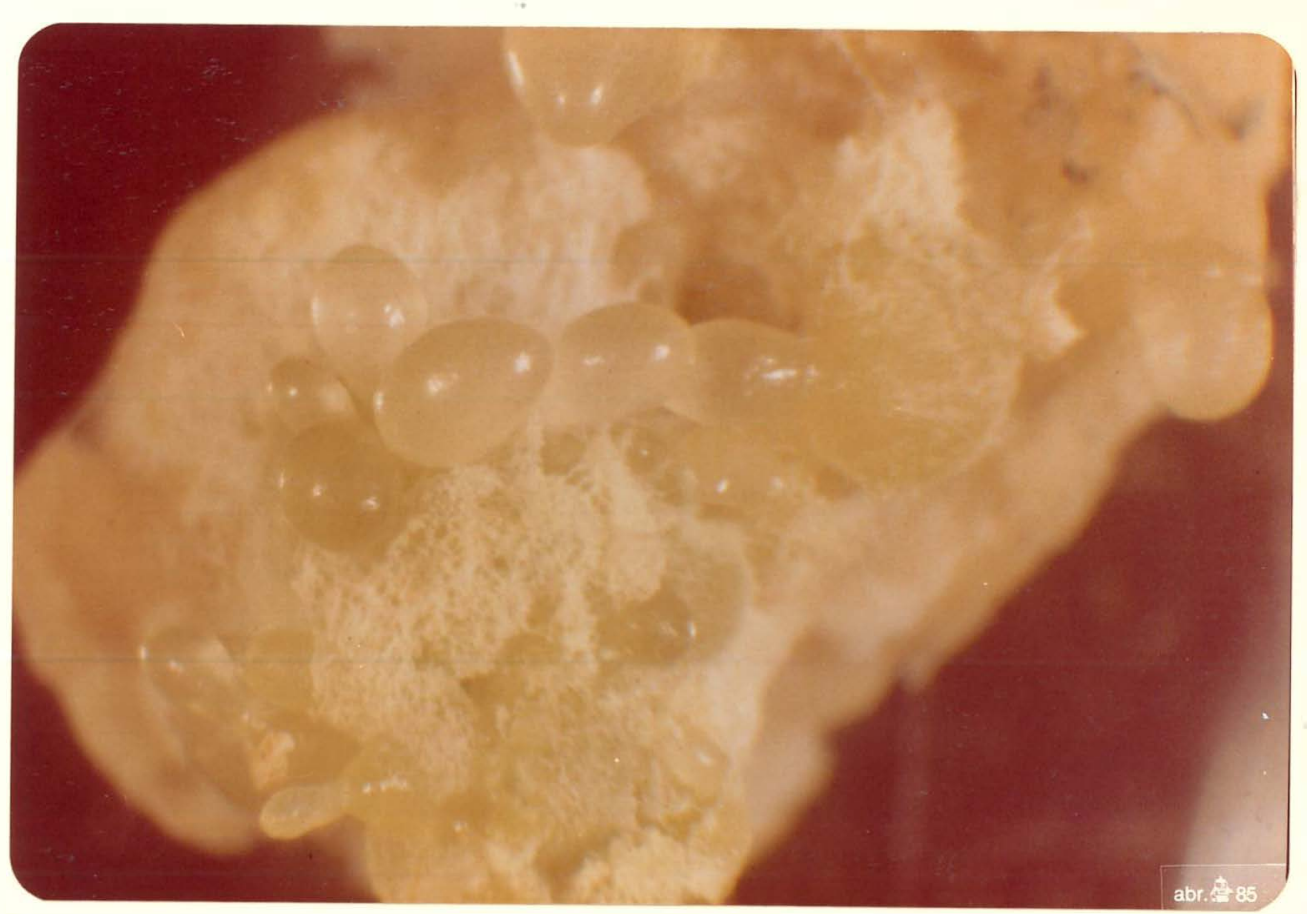

FIGURA 9. Calos de 'Pera' oriundos de óvulos abortivos evidenciando a pre sença de pro-embriōides. 
A presença de embriōides só foi verificada com aproximada mente 7 semanas de cultura, estando de acordo com observações anteriores (NAVARRO et alii, 1979) de que óvulos em cultura demoram mais para mostrar diferenciação (até 15 semanas sem nenhum sinal) do que nucelos. 0 meio pa ra este experimento só foi inoculado 1 mês após sua preparação. Isto eví dencia a presença de um determinado balanço. de substâncias como exemplo au xinas e citocininas no meio, que estaria inibindo os processos de embriogê nese e formação de calos. Com o envelhecimento do meio, talvez os niveis destas substâncias se aproximassem mais do ótimo, tendo sido degradadas principalmente pela luz.

Melhores resultados foram obtidos a partir de um determina do desenvolvimento do fruto $(1,62 \times 1,60 \mathrm{~cm})$ correspondendo a aproximada mente 6 semanas após a polinização (Tabela 10). Sucesso na cultura de övu los abortivos tem sido verificado desde a época da polinização até 5 meses depois, porém, com índices ötimos em torno de 6-8 semanas para 'Robertson', 'Valência' e 'Marsh', e até 10-12 semanas para 'Temple' (BIT'ERS et alii, 1970; KOCHBA et alii, 1972).

\subsection{Cultura de óvulos abortivos da cv. 'Pera' em diferentes meios}

Um nümero significativamente baixo de embriōides foi também obtido com a cv. 'Pera', quando diversas substâncias orgânicas e regulado res de crescimento foram adicionados ao meio de cultura (Tabela 11). Os indices mais elevados foram observados na presença de CH, EM, AC e EL, os quais não diferiram significativamente pelo teste de Tukey a $5 \%$, enquanto niveis inexpressivos se observaram com a adição de $A D$, Cin e 2,4-D. 
TABELA 11. Embriōides (No), plantas e calos (\%) obtidos em cultura de óvu los de 'Pera' em meio "MS" adicionado de diferentes substâncias de crescimento.

\begin{tabular}{|c|c|c|c|}
\hline TRATAMENTO & NO MÉDIO DE & EMBRIOIDES OUE & PRODUZIRAM (\%) \\
\hline $\mathrm{mg} / 1$ & EMBRIOIDES/OVULO & PLANTAS & CALOS \\
\hline$A A-40$ & $0,11 \quad d$ & 0 & 0 \\
\hline$E M-500$ & 1,20 a & 20 & 0 \\
\hline$E L-500$ & 0,66 abc & 80 & 0 \\
\hline$A C-10 \%$ & $1,00 \mathrm{ab}$ & 50 & 20 \\
\hline $\mathrm{CH}-400$ & 1,50 a & 65 & 0 \\
\hline$A D-40$ & $0,22 \mathrm{~cd}$ & 20 & 0 \\
\hline$A D-40+E M-500$ & $0,40 \mathrm{bcd}$ & 50 & 0 \\
\hline$A D-40+\operatorname{cin}-0,25$ & $0,20 \mathrm{~cd}$ & 60 & 0 \\
\hline$A D-40+N A A-0,25+A C i-2$ & $0,25 \quad \mathrm{~cd}$ & 20 & 0 \\
\hline Cin-0,5+2,4-D-2 & $0,00 \cdot d$ & 0 & 100 \\
\hline
\end{tabular}

As médias seguidas da mesma letra não diferem entre si pelo teste Tukey-5\%.

Estes resultados estão de acordo com observaçẽes de que o EM (BITTERS et alii, 1970; KOCHBA e SPIEGEL-ROY, 1973; NAVARRO et alii, 1979), CH (SABHARWAL, 1963) e AC (BUTTON e BORNMAN, 1971; MITRA e CHATURVE SI, 1972) promovem embriogênese em tecido nucelar de citros, e que auxinas e citocininas a inibem (ESAN, 1973). O EL pareceu exercer influência sig nificativa sobre a evolução dos embrióides em plantas, o qual segundo ESAN (1973), apesar de não ter efeito sobre a embriogênese, aumenta o desenvolvimento dos örgãos em cultura de nucelos.

4.5. Desenvolvimento de pseudobulbithos de 'Vatência'

A evolução de pseudobulbilihos para proembriōides e mesmo pạ 
ra embriōides não foi significativamente estimulada pela adição de substân cias orgânicas complexas e vários reguladores de crescimento, cujo compor tamento se mostrou estatisticamente igual ao tratamento testemunha (Tabe 1a 12). A proliferação de novos pseudobulbilhos ou calos globulares tam

TABELA 12. Desenvolvimento de pseudobulbilhos cultivados em meio "MS" adi cionado de diferentes substâncias de crescimento.

\begin{tabular}{|c|c|c|c|}
\hline \multirow{2}{*}{$\begin{array}{c}\text { TRATAMENTO } \\
\mathrm{mg} / 1\end{array}$} & \multicolumn{2}{|c|}{ NO MEDIO/FRASCO DE } & \multirow{2}{*}{$\begin{array}{l}\text { FRASCOS COM } \\
\text { CALOS }(\%)\end{array}$} \\
\hline & EMBRIOIDES & PROEMBRIOIDES & \\
\hline Testemunha ("MS") & 29,4 a & $34,9 a b$ & 55,6 \\
\hline$E M-2500$ & $19,4 a b$ & 34,1 ab & 71,4 \\
\hline$E M-2500+A D S-30$ & $17,6 a b$ & 46,2 a & 63,6 \\
\hline$E M-2500+B A P-20$ & $4,1 \quad b$ & $28,4 a b$ & 37,5 \\
\hline$A B S-40$ & $8,8 \mathrm{ab}$ & $32,7 a b$ & 30,0 \\
\hline $\mathrm{GA}_{3}-1$ & $20,1 a b$ & $28,2 a b$ & 45,5 \\
\hline $\mathrm{GA}_{3}-1+\mathrm{ADS}-30$ & $26,7 \mathrm{ab}$ & $23,0 \mathrm{ab}$ & 28,5 \\
\hline $\mathrm{GA}_{3}-10+\mathrm{ADS}-60$ & 16,5 ab & $20,8 \quad b$ & 48,6 \\
\hline $\mathrm{GA}_{3}-10$ & 17,7 ab & $39,4 a b$ & 50,0 \\
\hline $\operatorname{Cin}-0,1+\mid A A-1$ & $11,7 \mathrm{ab}$ & $32,6 a b$ & 34,6 \\
\hline Cin-1 $+\mid A A-0,1$ & 17,9 ab & 26,9 ab & 68,3 \\
\hline$A C-10 \%$ & 13,3 ab & 21,6 ab & 30,1 \\
\hline$C H-400+E L-500$ & $17,7 a b$ & $20,3^{\circ} \mathrm{b}$ & 47,7 \\
\hline
\end{tabular}

As médias seguidas da mesma letra não diferem entre si pelo teste Tukey-5\%.

bém apresentou valores elevados na testemunha comparada com os demais tra tamentos. Isto mostra que o meio básico "MS", acrescido de EM-500 mg/l, for nece as condições necessárias tanto para a evolução dos pseudobulbilhos em proembriōides e embriōides como para proliferaçáo de calos.

Estes resultados discordam em parte das observações feitas 
por vārios autores de que a formação de pseudobulbilhos com posterior trans formação em embriōides e plantas é estimulada por EM + AD (BUTTON e BORN MAN, 1971; STARRANTINO et alii, 1978), por CH (RANGASWAMY, 1961; SABHARWAL, 1963), e outras citocininas (RANGASWAMY, 1958; KOCHBA e SPIEGEL-ROY, 1976a).

Citocininas, embora não essenciais à embriogênese, estimulam a formação de calos (STARRANTINo et alii, 1978), o que foi comprovado pela adição de $\operatorname{cin}-1,0 \mathrm{mg} / 1+\mid A A-0,1 \mathrm{mg} / 1$, cuja combinação é tida como padrão para cultura de calos nucelares de citros (KOCHBA e SPIEGEL-ROY, 1973a).

\subsection{Irradiação de calos globulares de 'Valência'}

Observe-se na Tabela 13 e Figura 10 que houve um nitido de crēscimo no número de embrióides diferenciados à medida que se elevaram as doses de radiação gama. Não houve diferença significativa pelo teste. Tu key entre os tratamentos testemunha (sem irradiação) e a dose 3 kR, os quais diferiram estatisticamente de todos os demais.

TABELA 13. Número de embriōides obtidos de calos globulares submetidos a diferentes doses de radiação gama.

\begin{tabular}{|c|c|c|c|c|c|c|c|}
\hline DOSE (kR) & 0 & 3 & 6 & 9 & 12 & 15 & 18 \\
\hline Embriōides por & & & & . & . & & \\
\hline cultura (no) & $18,0 \mathrm{~A}$ & $15,5 \mathrm{~A}$ & $9,3 \mathrm{~B}$ & $3,8 \mathrm{C}$ & $0,9 \mathrm{D}$ & $0,3 D$ & $0,0 \quad D$ \\
\hline \multicolumn{8}{|l|}{ Embriōides } \\
\hline anorma is $(\%)$ & 16,5 & 22,5 & 38,9 & 41,4 & 63,8 & 51,1 & 58,2 \\
\hline
\end{tabular}

As mëdias seguidas da mésma letra não diferiram entre si pelo teste Tukey$5 \%$. 
Estes resultados discordam daqueles obtidos por SPIEGEL-ROY e KOCHBA (1973b), onde doses de 12 a 20 kR estimularam a embriogênese e, so. mente 28-32 kR apresentaram-se letais, porém, fazendo uso de uma baixa in tensidade de dose $(3,1 \mathrm{kR} / \mathrm{h})$, enquanto no presente trabalho se usou $97 \mathrm{kR} / \mathrm{h}$.

Obteve-se valores inexpressivos em $12 \mathrm{kR}$ e atingindo niveis letais a $18 \mathrm{kR}$, ao passo que, os mesmos autores testando uma dose de $16 \mathrm{kR}$, com intensidade de $100 \mathrm{kR} / \mathrm{h}$, observaram apenas um efeito depressivo sobre o nümero de embriōides. Trabalhos tem sido desenvolvidos (KOCHBA et alii, 1980) usando 8,12 e $16 \mathrm{kR}$ a $80 \mathrm{kR} / \mathrm{h}$, objetivando introduzir tolerância a niveis mais elevados de $\mathrm{NaCl}$ e 2,4-D.

A percentagem de embrióides anormais (fasciação, cotiledones agrupados e de tamanho diferente) na dose mais baixa de radiação ( 3 kR) foi praticamente igual a testemunha. Altos indices de anormalidade foram evi denciados nas doses mais elevadas de radiação (Tabela 13), o que está de acordo com observações anteriores feitas por JUAREZ et alii (1976); STARRAN TINO et alii (1978); entre outros.

Estes calos globulares se constituem numa excelente fonte de embriōides e um material interessante para a aplicação de agentes muta gênicos em estágios anteriores ao início do processo de embriogênese, sem restrições sazonais e considerando a evidência da origem unicelular de seus embriōides (BUTTON et alii, 1974). Células isoladas e protoplastos podem facilmente ser obtidos a partir destes calos e tratadas com mutagênicos, abrindo a possibilidade da aplicação de mëtodos de seleção aplicados a mi crorganismos. 


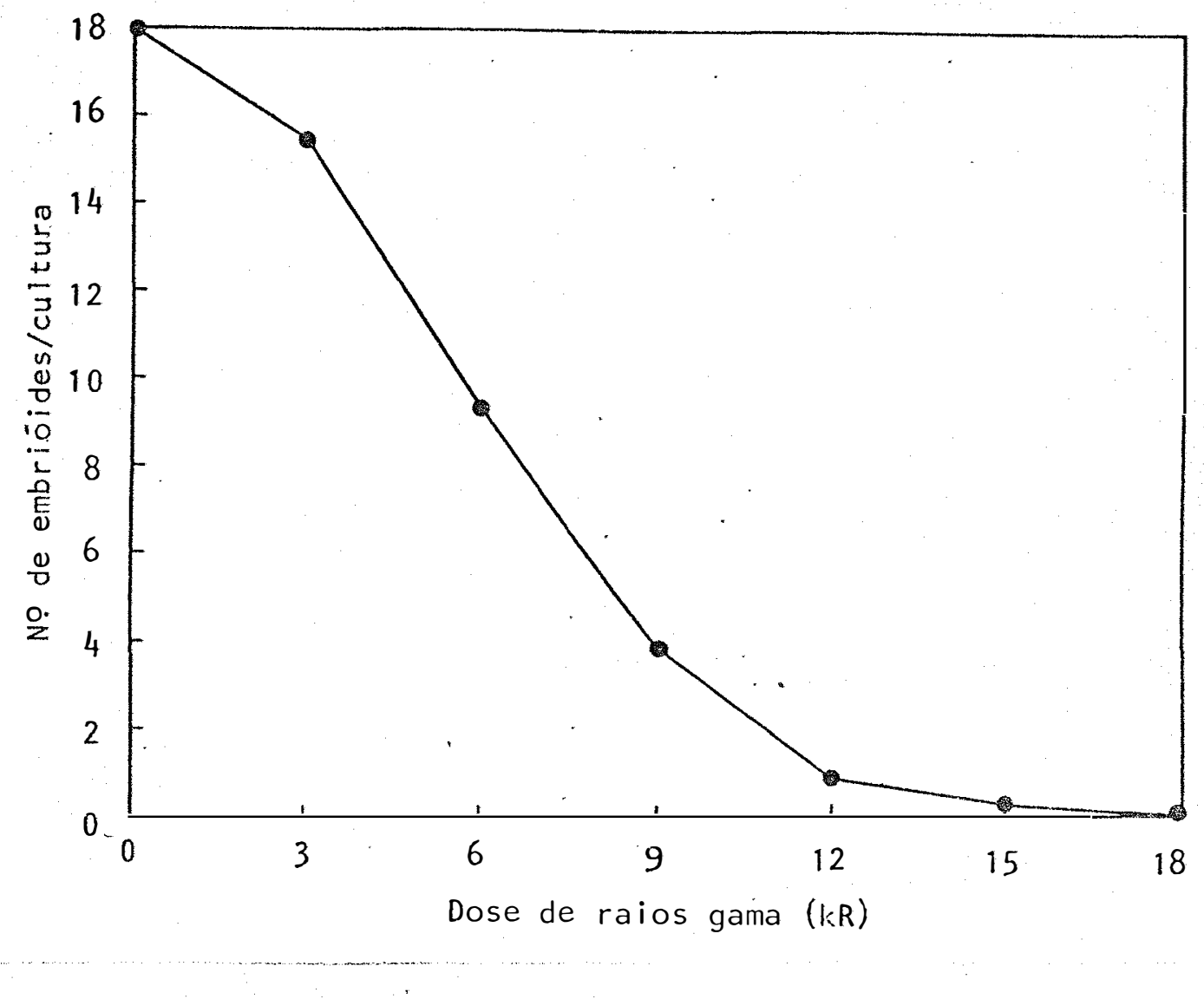

FIGURA 10. Número de embriōides obtidos de calos globulares submetidos a diferentes doses de radiação gama.

A sequência "uma célula à planta" foi estabelecida para uma série de cultivares de citros (VARDI e SPIEGEL-ROY, 1982) e, seu uso no me lhoramento teria grande impacto, superando uma série de problemas relacio nados com a reprodução sexuadadas espécies citricas.

4.7. Enraizamento de embriōides de 'Valência'

Uma vez atingido o tamanho de 3-6 mm (Figura 11) os embriōi 


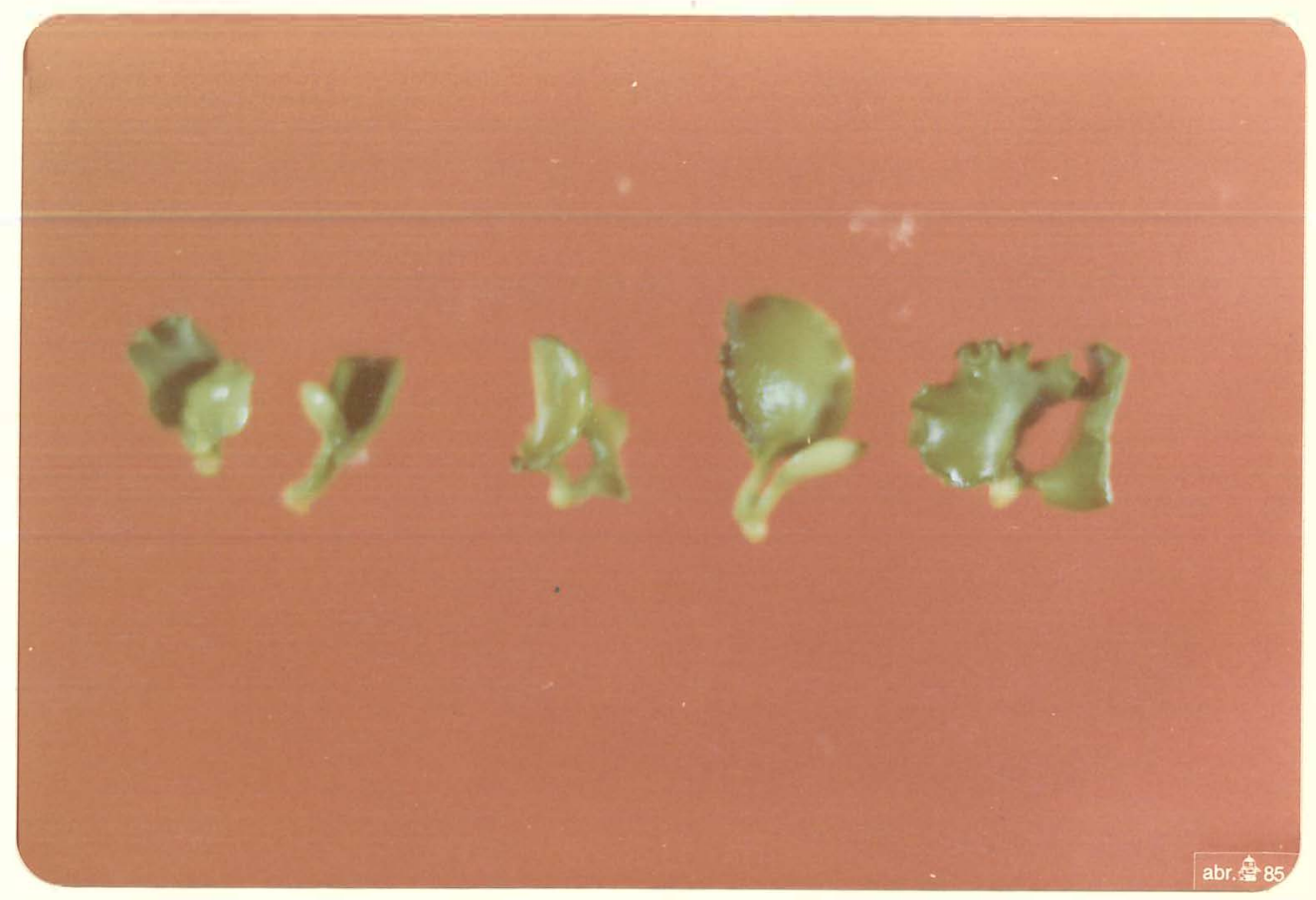

FrGURA 11. Embrióides de 'Valência' obtidos de nucelos após nove semanas de cultura em meio básico "MS".

des são individualizados para que tenha continuidade o processo de desen volvimento. Normalmente se dá primeiro a formação de raizes e depois da parte aérea (Figura 12). Ocorrendo o conträrio há uma inibição do desen volvimento das raizes.

Dentre os reguladores de crescimento, os principais respon sáveis pelo enraizamento de embrióides oriundos de calos nucelares, são o $\mathrm{GA}_{3}-1$ a $5 \mathrm{mg} / 1$ e o NAA-0,1 a $5 \mathrm{mg} / \mathrm{l}$ (Tabela 14). As maiores diferenças fó ram observadas destes hormônios para os demais tratamentos em embriōides considerados grandes (maiores que $6 \mathrm{~mm}$ ), tamanho normalmente utilizado pa ra a individualização em meio de enraizamento. A formação de raiz em em brióides médios (3-6 mm) e pequenos (menores que $3 \mathrm{~mm}$ ) não foi estimulada 


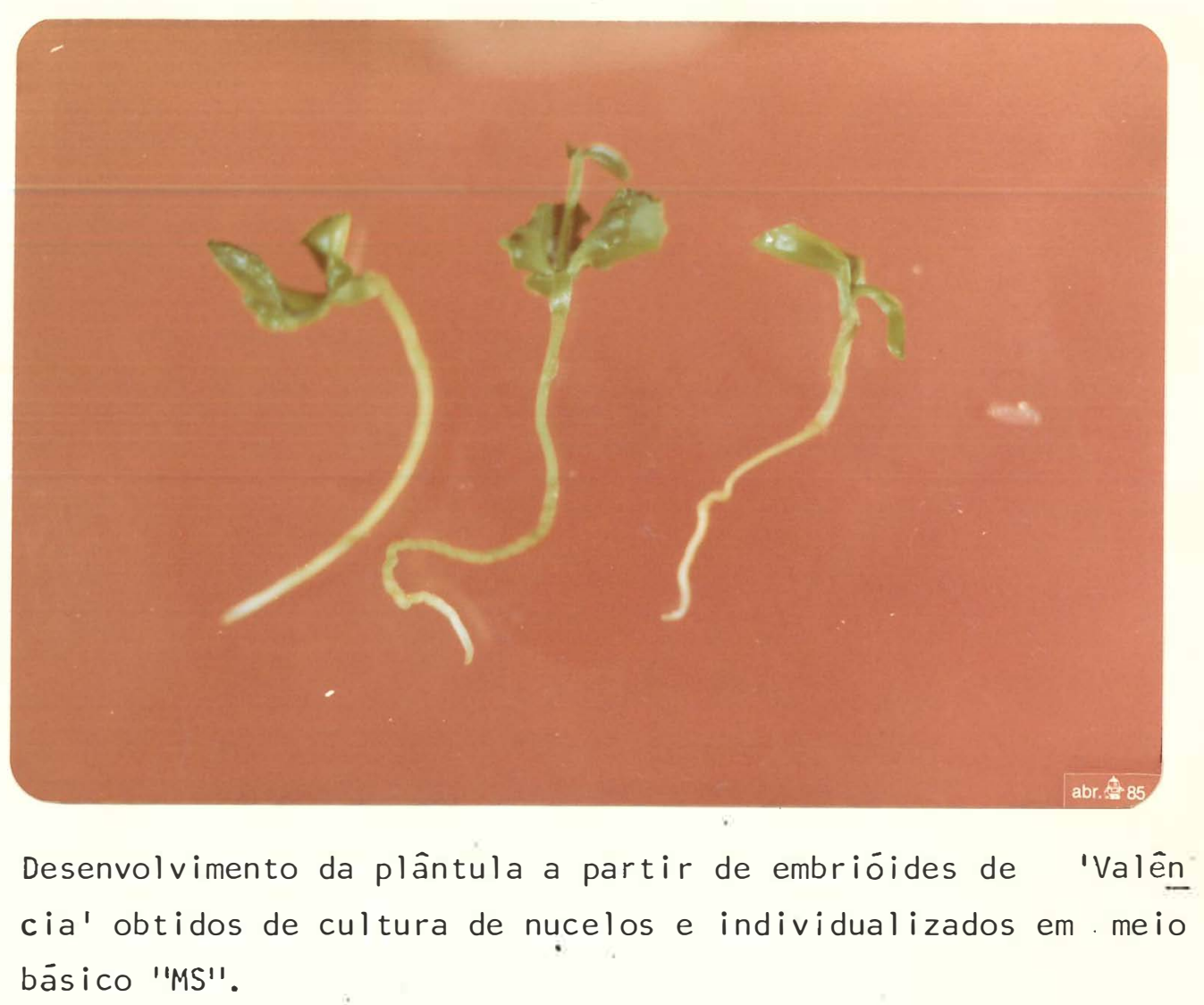

FIGURA 12. Desenvolvimento da plântula a partir de embrióides de 'Valên cia obtidos de cultura de nucelos e individualizados em - meio basico "MS".

peia adição de substâricias reguladoras do crescimenío, uma vez que não di feriram estatisticamente da testemunha. Comportamento similar tiveram os embriōides oriundos diretamente do nucelo, onde, embora a adição de $\mathrm{GA}_{3}-1$ $\mathrm{mg} / \mathrm{l}$ tivesse apresentado maior percentagem de enraizamento, não diferiu significativamente de NAA-0,1 e IBA-1,0 mg/1.

A ação do $\mathrm{GA}_{3}-1,0 \mathrm{mg} / 1$ sobre o enraizamento jā havia sido reportada (RANGASWAMY, 1961; KOCHBA et alii, 1972) com sucesso total para embrióides bem desenvolvidos e com valores variáveis dependendo da cultivar.

0 hormônio de enraizamento por excelência é o IBA, ö que não se verificou para embriōides oriundos de calos nucelares, mostrando inclu 
sive um efeito detrimental sobre os embriōides grandes, fato anteriormente evidenciado por KOCHBA e SPIEGEL-ROY (1976b). Estes autores atribuem tam bém ao NAA este mesmo efeito, discordando do evidente estímulo ao NAA em vārias concentrações $(0,1$ a $5,0 \mathrm{mg} / 1)$ sobre o enraizamento observado neste trabalho.

TABELA 14. Enraizamento de embriōides (\%) óriundos de calos nucelares e de nucelos em diversos hormônios adicionados ao meio "MS".

\begin{tabular}{|c|c|c|c|c|c|}
\hline \multirow{2}{*}{$\begin{array}{l}\text { TRATAMENTO } \\
\mathrm{mg} / 1\end{array}$} & \multicolumn{4}{|c|}{$\begin{array}{c}\text { TAMANHO DOS EMBRIOIDES ORIUNDOS } \\
\text { DE CALOS NUCELARES }\end{array}$} & \multirow{2}{*}{$\begin{array}{l}\text { EMBRIOIDES } \\
\text { ORIUNDOS DE } \\
\text { NUCELOS }\end{array}$} \\
\hline & GRANDE & MEDIO & PEQUENO & MED IA & \\
\hline "MS" & 52,3 cde & $40,9 a b c$ & $29,9 a b$ & $41,0 \mathrm{bcd}$ & $46,5 \mathrm{bc}$ \\
\hline $\mathrm{NAA}-0,1$ & $89,1 a$ & $53,1 a b$ & $38,2 a$ & $60,1 a$ & $54,0 a b c$ \\
\hline NAA $-1,0$ & 63,9 bcde & $49,8 a b$ & $32,4 a b$ & $48,7 a b c$ & $39,5 \mathrm{bc}$ \\
\hline$N A A-5,0$ & $64,8 a b c d$ & $46,5 a b c$ & $34,9 a b$ & $48,7 a b c$ & \\
\hline$I A A-1,0$ & 44,8 & $43,2 a b c$ & $16,6 a b$ & $34,9 \mathrm{~cd}$ & $28,5 \quad c$ \\
\hline $\mid B A-1,0$ & 23,2 & $39,8 a b c$ & $24,9 a b$ & 29,3 & $60,0 a b$ \\
\hline $\mathrm{GA}_{3}-1,0$ & $84,8 a b$ & $66,6 a$ & $37,3 a b$ & $62,9 a$ & $71,5 a$ \\
\hline $\mathrm{GA}_{3}-5,0$ & $75,7 a b c$ & $60,6 a b$ & $38,1 a b$ & $58,1 \mathrm{ab}$ & \\
\hline$A D S-27,0$ & 35,7 & $19,9 \quad c$ & $23,3 a b$ & 26,3 & \\
\hline $\mathrm{GA}_{3}-1,0+\mathrm{ADS}-27,0$ & 37,3 & $33,1 \mathrm{bc}$ & $13,3 \mathrm{~b}$ & 27,9 & \\
\hline
\end{tabular}

As médias seguidas da mesma letra não diferem entre si pelo teste Tukey- $5 \%$.

Um forte estímulo a formação de raiz foi observado quando plântulas obtidas "in vitro", apresentando apenas uma raiz principal, en curtada em aproximadamente 3 a $4 \mathrm{~cm}$, foram transferidas para meio suplemen tado com NAA-0,1 e 1,0 mg/l. Obteve-se até 20 novas raizes por planta em $15 \%$ das plantas sob a influência do NAA-1,0 mg/l (Tabela 15). 
.79 .

TABELA 15. Desenvolvimento do sistema radicular de plântulas de 'Valência' (que apresentavam apenas a raiz principal) em meio "MS" adicio nado de NAA.

\begin{tabular}{c|c||c|c}
\hline \multicolumn{2}{|c||}{ NAA-0,1 mg/l } & \multicolumn{2}{c}{ NAA-1,0 mg/l } \\
\hline \% DE PLANTAS & NO DE RAIZES & \% DE PLANTAS & NO DE RAIZES \\
\hline 12 & 8 & 15 & 20 \\
28 & 4 & 23 & 10 \\
36 & 1 & 18 & 5 \\
24 & (apenas a principal) & 44 & Algumas esporãdi \\
& 0 & & cas) \\
\hline
\end{tabular}

4.8. Cultura de gemas axilares

\subsubsection{Cultivar 'Valência'}

Como se observa na Tabela '16, houve para a cv. 'Valência'una diferença altamente significativa quanto a número médio de brotos com mais de $1 \mathrm{~cm}$ de comprimento entre os diversos níveis de NAA e BAP, e também pa ra a interação. Os desdobramentos de NAA dentro de BAP e de BAP dentro de NAA também mostraram significância ao nive! de $1 \%$ para todos os casos, ex ceto para NAA dentro de BAP-5,0 mg/1 e BAP dentro de NAA-5,0 mg/l.

Melhores resultados foram obtidos com NAA- 0,0 e $0,2 \mathrm{mg} / \mathrm{l}$ tan to em termos médios como principalmente na dose mais baixa de BAP $(0,2 \mathrm{mg} /$ 1). 0 BAP-0,2 mg/l foi significativamente superior aos demais tratamentos, tanto para a média como dentro de todos os niveị de NAA (Tabela 16, Figu ra 13). A combinação mais eficiente destes dois elementos se deu em NAA0,2 e BAP-0,2 mg/l (Figura 14) com uma produção média de 6,18 novos brotos 
TABELA 16. Número médio de brotos em cultura de gemas áxilares de 'Valên cia' em diferentes combinações de BAP e NAA.

\begin{tabular}{|c|c|c|c|c|c|c|c|c|c|}
\hline & \multicolumn{8}{|c|}{ NAA $(\mathrm{mg} / 1)$} \\
\hline & & \multicolumn{2}{|c|}{0,0} & 0,2 & \multicolumn{2}{|l|}{2,0} & - & 5,0 & Média \\
\hline \multirow{2}{*}{$\stackrel{\bar{\sigma}}{\bar{E}}$} & 0,0 & 0,82 & bc $A$ & $\begin{array}{l}0,77 \text { b } A B \\
42,8 *\end{array}$ & $\begin{array}{c}0,00 \\
33,3 *\end{array}$ & c & C & $\begin{array}{l}0,19 \mathrm{BC} \\
75,0 *\end{array}$ & $0,45 \mathrm{bc}$ \\
\hline & 0,2 & 3,71 & a $\quad A$ & 6,18 a $A$ & $2,00 \mathrm{a}$ & & B & $0,73 \quad c$ & $3,16 a$ \\
\hline \multirow{2}{*}{$\frac{a}{\infty}$} & 2,0 & 1,66 & b A & 0,81 b $A B$ & 0,64 & $b$ & $A B$ & $0,32 B$ & $0,86 \mathrm{~b}$ \\
\hline & 5,0 & 0,56 & c & $0,07 \quad b$ & 0,52 & $\mathrm{bc}$ & & 0,27 & $0,36 \mathrm{bc}$ \\
\hline \multicolumn{2}{|c|}{ Média } & 1,69 & $A$ & 1,96 & 0,79 & & B & $0,38 \mathrm{~B}$ & \\
\hline
\end{tabular}

* brotos com raiz (\%)

As médias seguidas da mesma letra (minúscula para níveis de BAP e maiūscu la para níveis de NAA) não diferem entre si pelo teste Tukey-5\%.

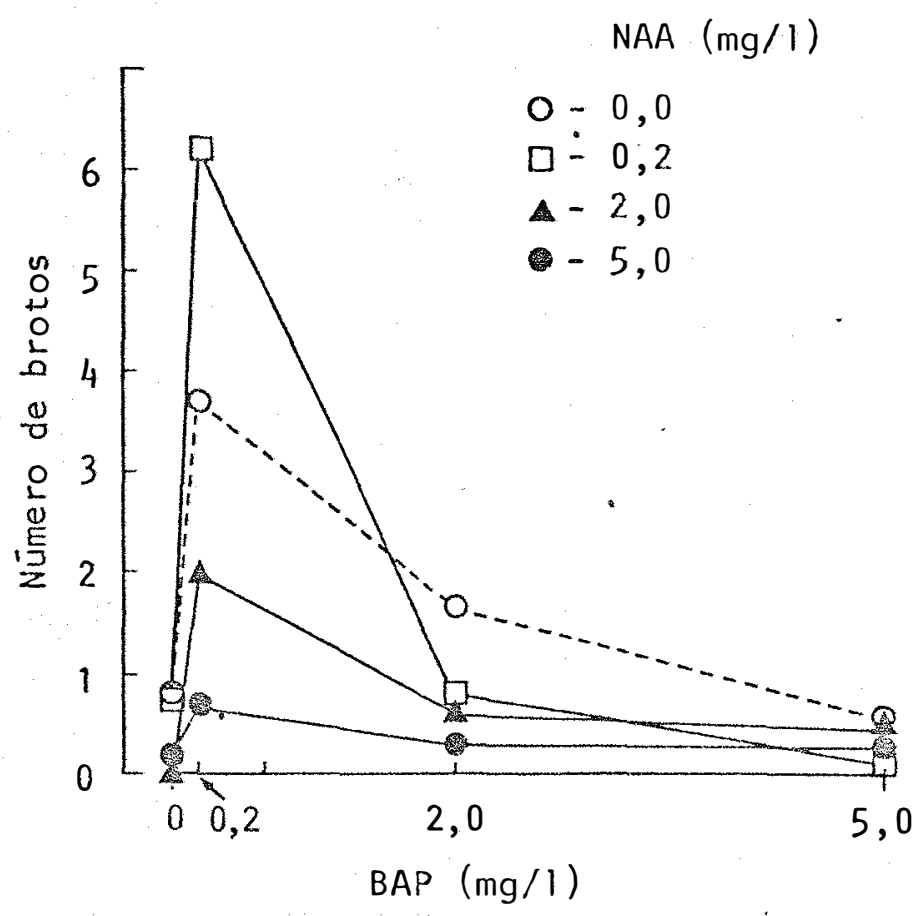

FIGURA 13. Nümero médio de brotos com mais de $1 \mathrm{~cm}$, obtidos em cultura de gemas axilares de 'Valência' em diferentes combinações 'de NAA e BAP. 


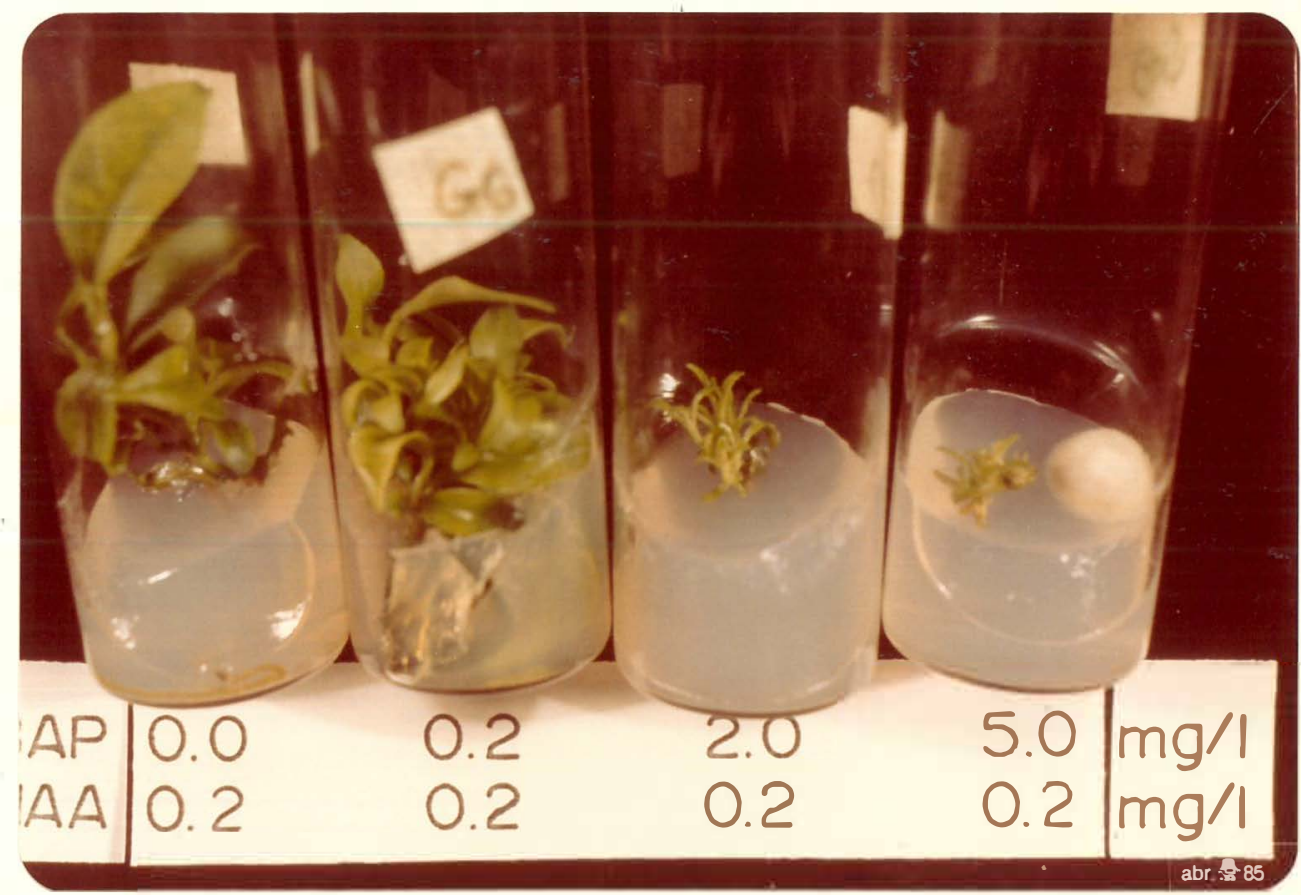

FigURA 14. Multiplicação de 'Valência' a partir de gemas axilares cultiva das em NAA-0,2 mg/l e värias concentrações de BAP.

com mais de $1 \mathrm{~cm}$ por gema cultivada "in vitro".

\subsubsection{Cultivar 'Trifoliata'}

$\mathrm{Na}$ cultura de gemas axilares de 'Trifoliata' houve uma dife rença altamente significativa com relação ao número de brotos, entre os di versos níveis de BAP e para a interação NAA $\times$ BAP. 0 desdobramento para BAP dentro de NAA foi significativo a $1 \%$ para todos os niveis de NAA, en quanto o desdobramento para NAA dentro de BAP mostrou-se com significância a $1 \%$ apenas dentro de BAP-5,0 e $10,0 \mathrm{mg} / 1$ (Tabela 17).

0 teste de Tukey a $5 \%$ indicou BAP-1,0 mg/l como o tratamento que produziu o maior número de brotos, diferindo de todos os demais para a 
.82.

média e dentro de câda nível de NAA, exceto para NAA-0,0 mg/l, onde BAP-1,0 e BAP-0,1 mg/l foram estatisticamente iguais (Tabela 17 e Figura 15).

TABELA 17. Nümero médio de brotos em cultura de gemas axilares de 'Trifo liata' em diferentes niveis de NAA e BAP.

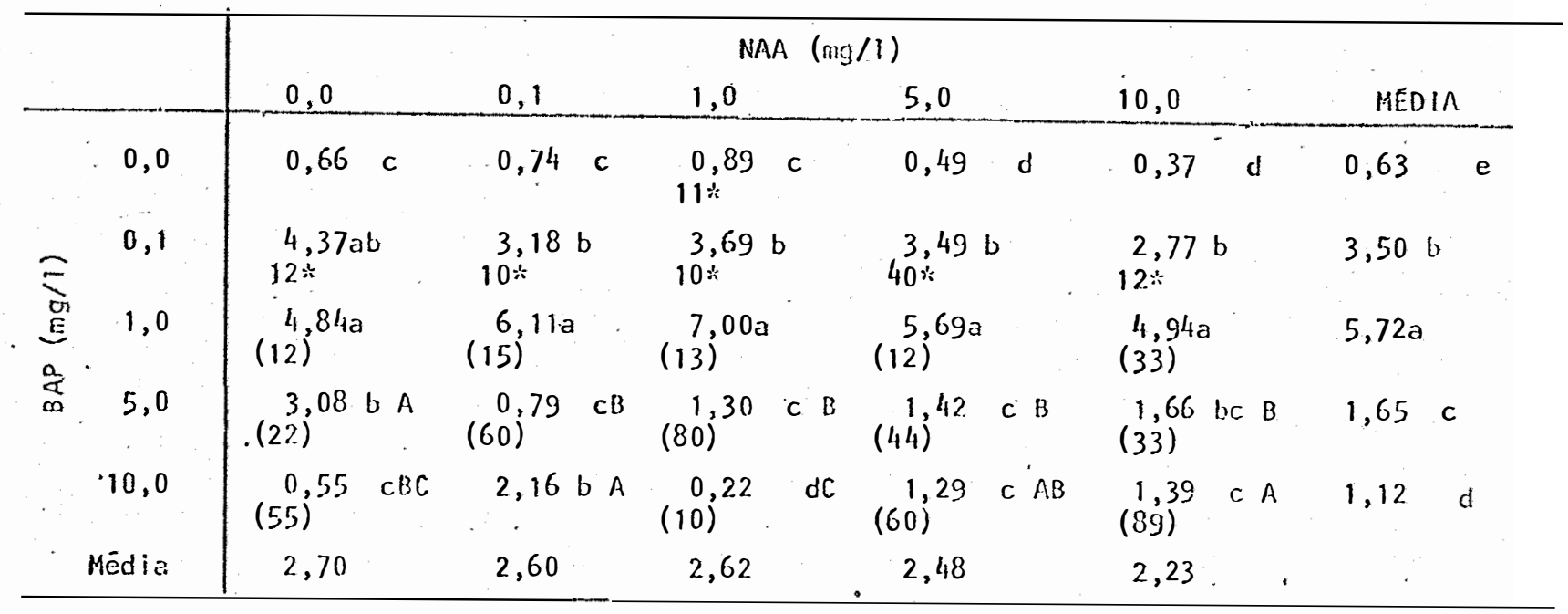

$*$ : brotos com raiz(\%); ( ) = explantes com calos

As médias seguidas da mesma letra (minüscula para níveis de BAP e maiūscu la para niveis de NAA) não diferem entre si pelo teste Tukey a $5 \%$.

A maior produção de brotos em 'Trifoliata' se deu com a com b inação $B A P-1,0$ e NAA-1,0 mg/l, porém, não diferindo estatisticamente de todas as demais doses de. NAA, neste nível de BAP.

Resultados similares foram obtidos por CHATURVEDI e MITRA (1974) com o cultivo de gemas axilares de Citrus grandis em meio suplemen tado por NAA-0,1 + BA-0,25 mg/1, produzindo até 20 a 30 novas gemas a par tir de um ünico explante. A adição de $C$ in-1,0 $+B A-1,0 \mathrm{mg} / 1$ (BOUZID, 1975) 


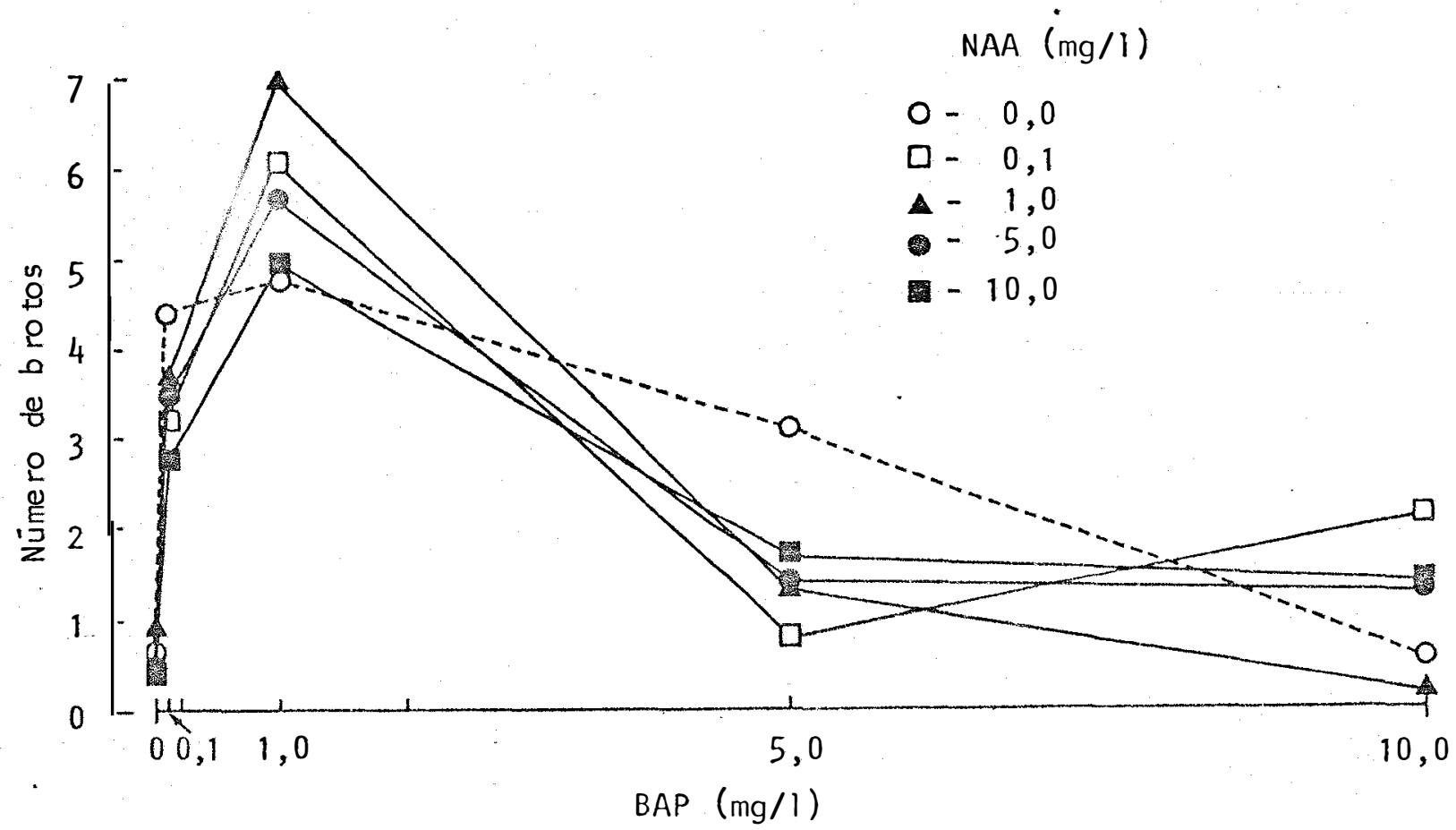

FrgURA 15. Número médio de brotos com mais de $1 \mathrm{~cm}$ obtidos em cultura de gemas axilares de 'Trifoliata' em diferentes combinações de NAA e BAP.

ou apenas de BA-0,5 a 2,0 mg/l (BARLASS e SKENE, 1982) tambēm promoveram uma boa multiplicação de gemas axilares.

Usando este sistema de propagação "in vitro", è possível re generar gemas adventícias e recuperar plantas geneticamente homogêneas de rivadas de camadas histogênicas diferentes de um indivíduo quimérico.

O tratamento mutagênico aplicado a um meristema apical dará origem a uma quimera setorial ou mericlinal. Estruturas periclinais podem ser obtidas por culturas repetidas de gemas axilares derivadas do ápice tra tado. Este procedimento, usado com a macieira (Malus domestica Borkh.) cv. 'Annurca' (DONINI, 1982), tem permitido um crescimento cont inuo e micropro 
.84 .

pagação do material até a geração $V_{2}$ em 4 meses, facilitando o isolamento de mutações somáticas induzidas e aumentando sua frequência. Os ramos $V_{2}$ podem ser enraizados ou enxertados, originando em 6 meses plantas $v_{3}$ pron tas para serem levadas ao campo.

As doses mais elevadas de BAP (a partir de $1,0 \mathrm{mg} / 1$ - Tabe la 17), independentemente da presença de NAA, evidenciaram alta percentagem de explantes que formaram calos. Estes calos de coloração esverdeada cres ceram abundantemente e mostraram elevada capacidade de regeneração de plan tas, constituindo-se num material muito interessante para estudos de indu ção de mutações.

Formação de calos a partir de segmentos de caule e folha com posterior diferenciação de plantas foi anteriormente registrado por muitos autores (GRIMBLAT, 1972; CHATURVEDI e MITRA, 1974; BHANSALY e ARYA, 1979), utilizando värias concentrações de NAA e BAP em diferentes cultivares.

0 comportamento de vários genótipos, no caso 'Valência' e 'Trifoliata', não é o mesmo frente a diferentes combinações de auxina e ci tocinina, o que evidencia a necessidade deste tipo de trabalho para cada cultivar, até mesmo dentro de uma mesma espécie.

4.8.3. Enraizamento de brotos

0 meio adicionado de NAA-0, 1 ou $1,0+\mid B A-2,0 \mathrm{mg} / 1$ foi o que proporcionou o maior indice de enraizamento de brotos para 'Valência', en quanto para 'Trifoliata' os melhores resultados foram obtidos com IBA-2,0 $\mathrm{mg} / 1$ e NAA-5,0 + BAP-0,1 mg/l (Tabela 18, Figura 16). 
TABELA 18. Enraizamento de brotos (\%) de 'Valência' e 'Trifoliata' emmeio "MS" suplementado por värios reguladores de crescimento.

\begin{tabular}{|c|c|c|}
\hline \multirow{2}{*}{$\begin{array}{c}\text { TRATAMENTO } \\
\mathrm{mg} / \mathrm{l}\end{array}$} & \multicolumn{2}{|c|}{ ENRAIZAMENTO (\%) } \\
\hline & 'Valência' & 'Trifoliata' \\
\hline$N A A-0,1$ & 43,0 & $31,5 \quad c$ \\
\hline$N A A-0,5$ & 53,0 & 11,0 \\
\hline$N A A-1,0$ & 81,0 bc & $27,0 \quad \mathrm{~cd}$ \\
\hline$N A A-5,0$ & 26,0 & 15,0 \\
\hline $\mid B A-1,0$ & $85,0 \mathrm{bc}$ & $53,0 a b$ \\
\hline $\mid B A-2,0$ & $77,0 \quad c$ & 63,5 a \\
\hline $1 B A-5,0$ & $60,5 \mathrm{~d}$ & - \\
\hline $1 \mathrm{BA}-10,0$ & 61,5 de & - \\
\hline NAA- $0,1+I B A-2,0$ & 91,0 ab & 36,5 bc \\
\hline$N A A-1,0+1 B A-2,0$ & 96,0 a & $52,0 \mathrm{ab}$ \\
\hline$N A A-1,0+1 B A-5,0$ & 44,5 de & - \\
\hline NAA $-5,0+1 B A-2,0$ & 60,0 & $30,0 \quad c$ \\
\hline NAA $-5,0+$ BAP- 0,1 & 53,5 & 60,0 a \\
\hline $\mathrm{GA}_{3}-5,0$ & 12,5 & 8,5 \\
\hline
\end{tabular}

As médias seguidas da mesma letra não diferem entre si pelo teste Tukey-5\%.

o NAA-0, 1 a $2,5 \mathrm{mg} / 1$ sozinho ou combinado com alguma citoci nina é citado como sendo o hormônio responsāvel pelo enraizamento de bro tos de värias espécies de citros (RANGASWAMY, 1975; BARLASS e SKENE, 1982). Este acentuado efeito do NAA também foi observado, antes da individualização dos brotos para meio de enraizamento, para 'Valência' na ausência de BAP (Tabela 16) e para 'Trifoliata' com adiçạo de BAP-0,1 mg/l (Tabela 17). 
.86 .

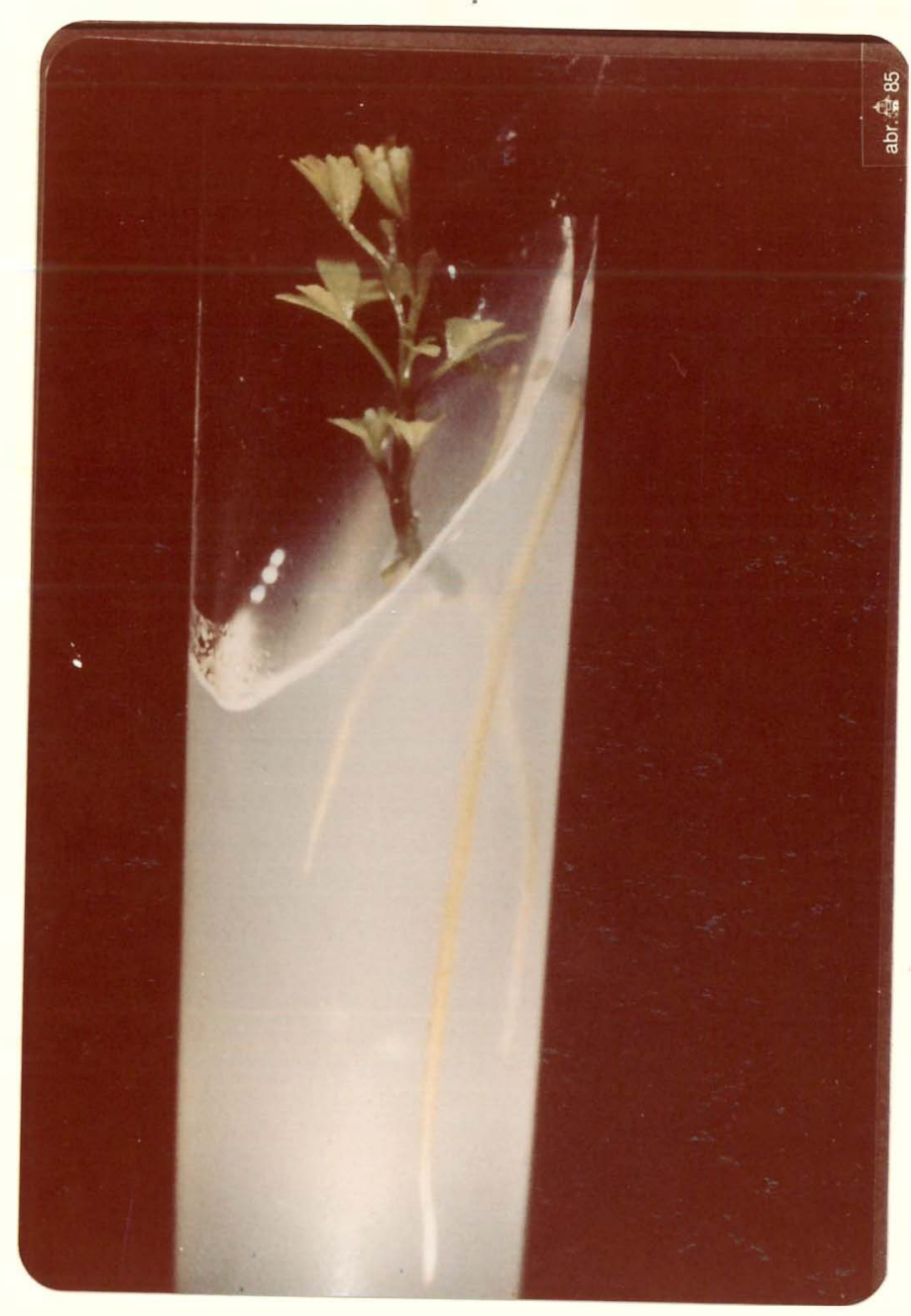

FIGURA 16. Enraizamento de brotos de 'Trifoliata' em meio "MS" adicionado de $\mid B A-2,0 \mathrm{mg} / 1$.

4.9. Cultura de segmentos do fruto de 'Pera'

Calos a partir de albedo e vesículas de frutos jovens de'Pe ra' foram obtidos praticamente em todas as combinações de Cin e 2,4-D (Ta bela 19), e Cin e IAA (Tabela 20). Todos estes calos continuaram sendo mantidos a luz ou no escuro por longos períodos, com transferências a in tervalos de 2 meses, em meio suplementado por Cin-0,25 + 2,4-D-0,5 mg/l, apresentando öt imo crescimento. 
TABELA 19. Produção de calos (\%) da cv. 'Pera' a partir de albedo e ves r culas em meio "MT" adicionado de diferentes concentrações de Cin e 2,4-D.

\begin{tabular}{|c|c|c|c|c|c|}
\hline \multirow{2}{*}{$\begin{array}{l}\text { TRATAMENTO } \\
\mathrm{mg} / \mathrm{l}\end{array}$} & \multicolumn{2}{|c|}{$\begin{array}{r}\% \text { DE EXPLA } \\
\text { ALBEDO }\end{array}$} & \multicolumn{2}{|c|}{$\frac{\text { COM CALOS }}{\text { VESICULAS. }}$} & \\
\hline & LUZ & ESCURO & LUZ & ESCURO & \\
\hline Cin-0,0+2,4-D-0,0 & 100 & 40 & 0 & 0 & \\
\hline Cin-0,0 $+2,4-D-0,5$ & 100 & 80 & 100 & 80 & \\
\hline Cin-0,0+2,4-D-1,0 & 100 & 60 & 100 & 80 & \\
\hline Cin-0,0 $+2,4-D-2,0$ & 60 & 40 & 100 & 100 & \\
\hline Cin-0,25+2, 4-D - 0,0 & 100 & 70 & 100 & 100 & \\
\hline Cin-0,25+2, 4-D-0, 5 & 100 & 75 & 100 & 20 & \\
\hline Cin-0,25+2, 4-D-1,0 & 100 & 0 & 100 & 100 & \\
\hline C.in-0,25+2, 4-D-2,0 & 100 & 50 & 100 & 100 & \\
\hline Cin-0,5 $+2,4-D-0,0$ & 75 & 40 & 40 & 25 & \\
\hline Cin-0,5 $+2,4-D-0,5$ & 100 & 60 & 100 & 100 & \\
\hline Cin-0,5+2,4-D-1,0 & 100 & 50 & 100 & 100 & . \\
\hline Cin-0,5+2,4-D-2,0 & 75 & 20 & 100 & 70 & \\
\hline $\operatorname{Cin}-1,0+2,4-D-0,0$ & 0 & 0 & 60 & 60 & \\
\hline $\operatorname{Cin}-1,0+2,4-D-0,5$ & 100 & 0 & 100. & 75 & \\
\hline Cin-1,0+2,4-D-1,0 & 60 & 40 & 100 & 100 & \\
\hline Cin-1,0 $+2,4-D-2,0$ & 25 & 100 & 50 & 100 & \\
\hline
\end{tabular}

Nenhum sinal de crescimento de calos foi observado nos seg mentos de flavedo.

Indução e crescimento de calos a partir de segmentos de fru tos citricos foram verificados por alguns autores (EINSET, 1978; NITSCH, 1965; KATO, 1980) para várias espécies, utilizando muitas combinações de auxinas e citocininas e, de modo geral, caracterizando 2,4-D e IAA como hor mônios indutores de calos nestes tecidos. 
.88.

TABELA 20. Producão de calos (\%) da cv. 'Pera' a partir de albedo e vesí culas em meio "MT" adicionado de diferentes concentrações de Cin e IAA.

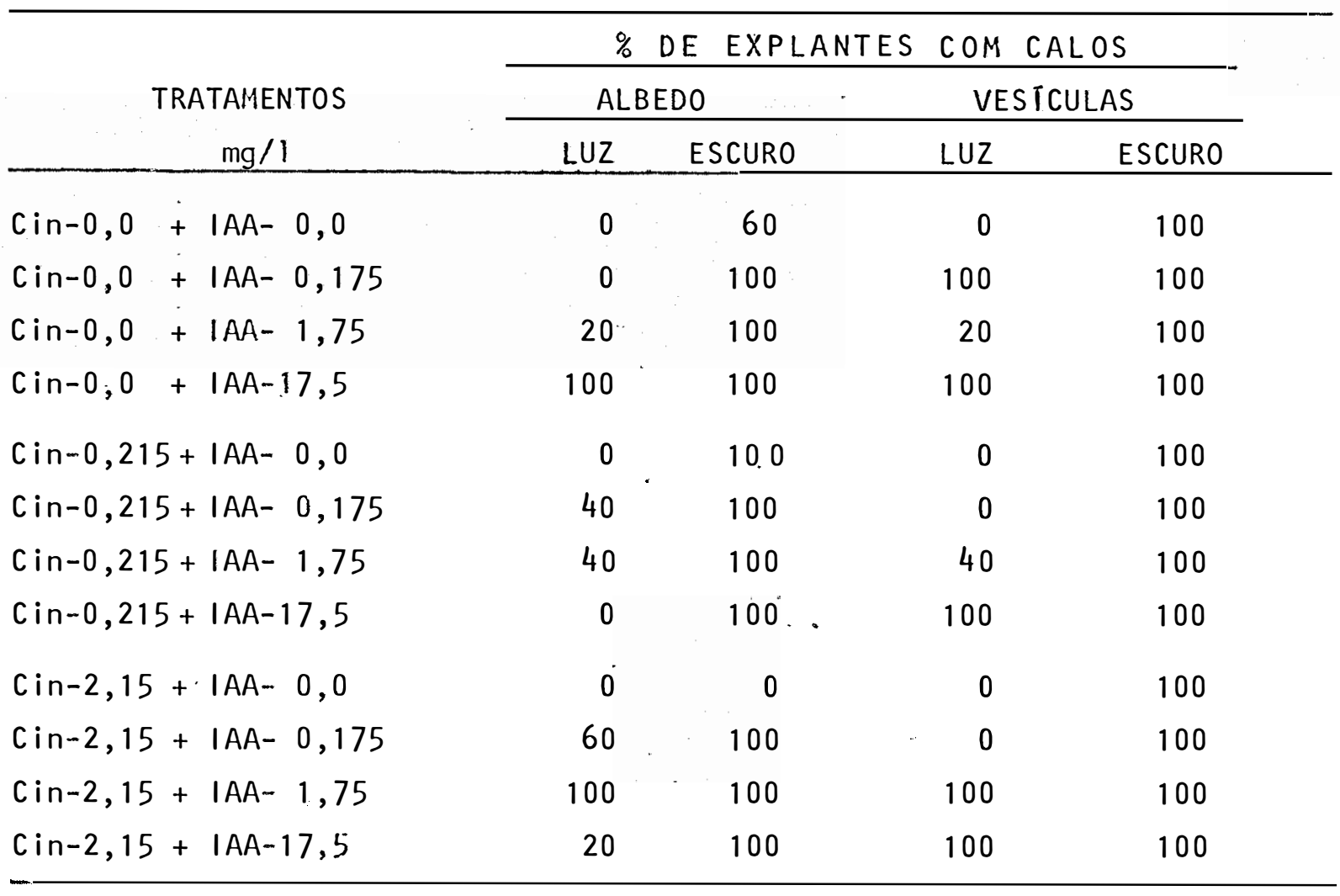

Não se obteve até então regeneração de plantas destes calos, porể, os mesmos se prestam para estudos de fenômenos morfológicos, citoló gicos e fisiológicos que podem ser conduzidos "in vitro", alheios à comple xidade de fatores que interagem na planta e. às limitações de natureza sazo nal.

4.10. Remoção das plantas para o solo

Tem se conseguido um indice próximo a 100\% de sobrevivência utilizando o seguinte procedimento: 
- Plântulas com 2-3 pares de folhas (Figura 17) são removidas dos tubos de ensaio e lavadas em água corrente para eliminar os restos de meio de cultura a elas aderido.

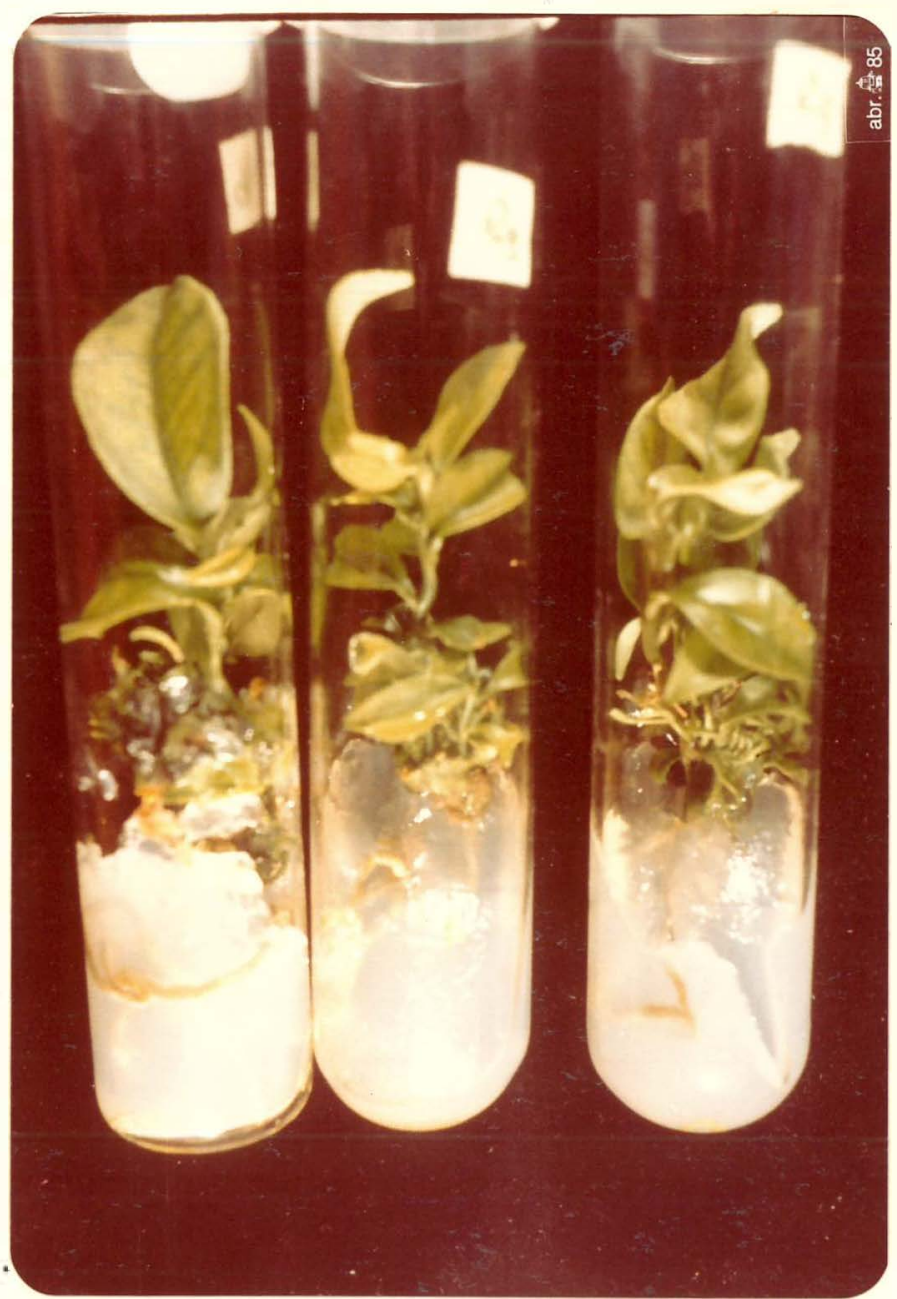

FIGURA 17. Plântulas de 'Valência' obtidas de cultura de nucelos, prontas para serem removidas dos tubos de ensaio para o solo.

- Nos casos em que o meio apresenta alguma contaminação, faz-se uma imer são das plântulas em uma solução com fungicida (Benomyl-0,6\%) por apro $x$ imadamente 5 minutos.

- A seguir, as plântulas são acondicionadas em potes plásticos contendo 
uma mistura de terra, esterco e areia $(4: 2: 1)$, e mantidas em câmara úmida, onde a umidade é fornecida por um umidificador e cujo indice é controlado por um "time-switch".

- Nestas condições, são mantidas por aproximadamente 10 dias, sendo que a cada dia procede-se uma diminuição do indice de umidade.

- Posteriormente, em casa de vegetação, permanecem em torno de 1 mês, quando são transferidas para sacos plásticos maiores ou vasos com o mesmo substrato (Figura 18 ).

FIGURA 18. Plântula de 'Valência' obtida de cultura de nucelos, com apro ximadamente 1 ano após a remoção dos tubos de ensaio. 
- Durante todo este período, as plântulas são umedeciidas com a solução nutritiva de HOAGLAND.

Uma vez bem estabelecidas as plântulas são selecionadas de acordo com o objetivo proposto. 
.92.

5. CONCLUSOES

Para as condições em que o presente trabalho foi desenvolvi do conclue-se que:

a) A data limite para extração dos nucelos da cultivar 'Valência'é 12 semanas apōs a polinização.

b) Pode-se obter "in vitro" até 12 embriōides diretamente de" um único nucelo, sem a adição de reguladores de crescimento.

c) Adição de auxinas e citocininas inibe a embriogênese em nucelos e o desenvolvimento de embrióides.

d) Hā uma formação esporādica de calos globulares altamente embrio gênicos a partir de nucelos, independentemente do meio de cultu ra e, mais marcante com adição de cinet ina-0,25+2,4-D-0,5 $\mathrm{mg} / 1$.

e) 0 aumento das doses de radiação gama sobre nucelos provoca uma redução do nümero de embriōides, acentuada em fases mais distan tes da inoculação. 
f) Para indução de mutações em cittros pode-se recomendar as doses de 1,0 a 2,0 kR, aplicadas a nucelos por ocasião da inoculação ou uma semana depois.

g) A irradiação apenas do meio de cultura aumenta a proliferação de calos, principalmente em doses mais elevadas ( $12 \mathrm{kR}$ ).

h) Há um elevado índice de anormalidades nos embrióides, o qual acentua-se com as doses mais altas de radiação, originando, po rém, plantas aparentemente normais.

i) Ovulos abortivos de 'Pera' originam embriōides à luz e calos al tamente embriogênicoss no escuro. O número de embriōides obti dos com 'Pera' é significativamente inferior ao de 'Valência'.

j) Há uma crescente redução do número de embrióides diferenciados de calos nucelares com o aumento das doses de radiação gama, sen do letal em $18 \mathrm{kR}$.

k) 0 enraizamento de embriōides é melhor estimulado pela adição de $\mathrm{GA}_{3}-1,0 \mathrm{mg} / 1$ ou NAA $-0,1 \mathrm{mg} / 1$.

1) A multiplicação de gemas de 'Valência' é mais estimulada por NAA $0,2+B A P-0,2 \mathrm{mg} / 1$ e de 'Trifoliata' por NAA-1,0 + BAP-1,0 mg/l; doses mais altas de BAP (acima de $1,0 \mathrm{mg} / \mathrm{l}$ ) produzem calos com elevado potencial morfogenético.

m) Melhor enraizamento de brotos de 'Valência' é obtido com NAA0,1 a $1,0+\mid B A-2,0 \mathrm{mg} / 1$ e de 'Trifoliata' com IBA-1,0 a $2,0 \mathrm{mg}$ 1 , ou NAA-5,0 + BAP-0,1 mg/l, ou NAA-1,0+IBA-2,0 mg/1. 
.94

n) Calos de albedo e vesículas são obtidos de praticamente todas as combinações de cinetina + 2,4-D e de cinetina + IAA, porēm, sem regeneração de plantas. 


\section{LITERATURA CITADA}

ALTMAN, A. e R. GOREN, 1971. Promotion of callus formation by abscisic acid in Citrus bud cultures. Plant Physiology. Washington, 47:844-846.

ALTMAN, A. e R. GOREN, 1974. Growth and dormancy cycles in Citrus bud cultures and their hormonal control. Physiol. Plantarum. Kopenhagen, $\underline{30}(3): 240-245$.

ALIMAN, A. e R. GOREN, 1977. Horticultural and physiological aspects of citrus bud culture. Acta Horticulturae. 78:51-50.

BACCHI, O., 1943. Cytological observations in citrus: 111. Megasporogenesis, fertilization and polyembryony. Bot. Gaz. Chicago, 105:221225.

BAR-AKIVA, A.; J. SAGIV e O. REUVENI, 1974. Physiological approaches to plant nutrition problems. Proc. 7th Int. Colloq. Plant Analysis and Fertilizer Problems. Hannover, W. Germany, :13-23.

BARLASS, M. e K.G.M. SKENE, 1982. In vitro plantlett formation from citrus species and hybrids. Scientia Horticulturae. 17:333-341.

BEN-HAYYIM, G. e J. KOCHBA, 1982. Growth characteristics and stability of tolerance of citrus callus cells subjected to $\mathrm{NaCl}$ stress. Plant. Science Letters. Amsterdam, 27(1):87-94. 
BHANSALY, R.R. e H.C. ARYA, 1978. Differentiation in explant of Citrus paradis $i$ Macf. (grapefruit) grown in culture. Indian J. Exp. Biol. New Delhi, India, 16:409-421.

BHANSALY, R.R. e H.C. ARYA, 1979. Organogenes is in Citrus limettioides (Sweet lime) callus culture. Phytomorphology. New Delhi, India, 29: 97-100.

BITTERS, W.P.; T. MURASHIGE; T.S. RANGAN e E. NAUER, 1970. Investigations on established virus-free citrus plants through tissue culture: Calif. Citrus Nurserymen's Soc. Los Angeles, California, 9:27-30.

BOTTINO, P.J., 1975. The potential of genetic manipulation in plant cell cultures for plant breeding. Radiation Botany. 15:1-16.

BOUZID, S.M., 1975. Quelques traits du comportement de boutures de Citrus en culture in vitro. C. R. Hebed. Seances Acad. Sci. Paris, Serie D, 280:1689-1692.

BRUNET, G. e R.K. IBRAHIM, 1973. Tissue culture of Citrus peel and its potential for flavonoid synthesis. Z. Pflanzenphysiol. Berlin, 69: $152-162$.

BUTTON, J. e C.H. BORNMAN, 1971. Development of nucellar plants from unpollinated and unfertilised ovules of the washington navel orange in vitro. Journal South African Botany. 37(2):127-134.

BUTTON, J. e C.E.J. BOTHA, 1975. Enzymatic maceration of Citrus callus and the regeneration of plants from single cells. Journal of Experimental Botany. Oxford, London, 26(94):723-729.

BUTTON, J. e J. KOCHBA, 1977. Tissue culture in the citrus industry. In: REINERT, J. e Y.P.S. BAJAJ (Eds.). Applied and fundamental aspects of plant cell, tissue, and organ culture. Berlin, Springer-Verlag: $70-92$. 
BUTTON, J.; J. KOCHBA e C.H. BORNMAN, 1974. Fine structure of and embryoid development from embryogenic ovular callus of "shamouti" orange (Citrus sinensis 0sb.). Journal of Exp. Bot. Oxford, London, 25(85): 446-457.

BUTTON, J. e F.H.J. RIJKENBERG, 1977. The effect of subculture interval on organogenesis in callus cultures of "Citrus sinens is". Acta Horticulturae. $78: 225-235$.

BUTTON, J.; A. VARDI e P. SPIEGEL-ROY, 1976. Root peroxidase isoenzymes as an aid in citrus breeding and taxonomy. Theoretical and Applied. Genetics. Berlin, 47:119-123.

CAILLOUX, M. 1984. Plant tissue culture: rapid propagation, induced mutations, and the potential role of protoplast techniques. In: VOSE, P.B. E S.G. BLIXT. CROP BREEDING (A COMTEMPORARY BASIS), New York, p. $311-346$.

CAMERON, J.'ं. e H.B. FROST, 1968. Genetics, breeding, and nucellar embriony. In: REUTHER, W.; L.D. BATCHELOR e H.J. WEBBER, Ed. The Citrus Industry. Berkeley, University of California Press, $2: 325-370$.

CAMERON, J.W. e R.K. SOOST, 1989. Citrus. In: Outlines of perenial crop breeding in the tropics. Wageningen, $H$. Veenman and Zonen,:129-162.

CHATURVEDI, H.C.; A.R. CHOWDHURY e G.C. MITRA, 1974. Shoot-bud differentiation in stem-callus tissue of Citrus grandis and correlated changes in its free amino acid content. Current Science. Bangalore, India, $\underline{43}(7): 536-537$.

CHATURVEDI, H.C. e G.C. MITRA, 1974. Clonal propagation of Citrus from somatic callus cultures. HortScience. Virginia, USA, $\underline{9}(2): 118-120$.

CHOUREY, P.S.; H.H. SMIIH E N.C. COMBATTI, 1973. Effects of $X$ irradiation and indolacetic acid on especific peroxidase isozymes and pith tissue of a Nicotiana amphiploid. Amer. J. Bot. Ohio, 60(9):853-857. 
DEIDDA, D. 1973. Embrioni nucellari di.clementine ottenuti in vitro. Revista della Ortofloro-frutticoltura Italiana. 54(4):291-296.

DEVREUX, M. 1973. In vitro culture and mutation breeding. In: Induced. Mutations in Vegetatively Propagated Plants. Vienna, IAEA, 41-51.

DONINI, B. 1982. Mutagenesis applied to improve fruit trees. In: Induced. Mutations in Vegatatively Propagated Plants II (Proc. Res. Co-ordination Meet., Coimbatore, 1980). Vienna, IAEA, 29-36.

EINSET, J.W. 1978. Citrus Tissue Culture: stimulation of fruit explant cultures with orange juice. Plant Physiology. Washington, 62(6): $885-888$.

ERNER, Y.; O. REUVENI e E.E. GOLDSCHMIDT, 1975. Partial purification of a growth factor from orange juice which affects Citrus tissue culture and its replacement by citric acid. Plant Physiol. Washington, 56: 279-282.

ESAN, E.B. 1973. A detailed study of adventive embryogenesis in the rutaceae. University of California, Riverside (dissertação), 233 p. ESïN, A. e R.K. SOOST, 1976. Peroxidase polymorphism in Citrus. J. Hered. Washington, 67:199-203.

ESEN, A. e R.K. SOOST, 1977. Adventive embryogenesis in Citrus and its relation to pollination and fertilization. Am. J. Bot. Ohio, 64(6): 607-14.

FROST, H.B. e R.K. SOOST, 1968. Seed reproduction: development of gametes and embryos. In: REUTHER, W.; L.D. BATCHELOR e H.J. WEBBER, Ed. The Citrus Industry. Berkeley, University of California Press, $\underline{2}: 290-324$. GALSTON, A.W. e P.J. DAVIES, 1969. Hormonal regulation in higher plants. Science. Washington, 163:1288-1289. 
GILADI, I.; A. ALTMAN e R. GOREN, 1979. A method for aseptic culture of bud explants from citrus trees. Scientia Horticulturae. 10:357-362.

GILFILLAN, I.M.; J.A. STEVENSON e W. KOEKEMOER, 1974. Gibberellic acid reduces creasing in late-season navels. Citrus and Subtrop. Fruit J. 482:4-5.

GRIMBLAT, U., 1972. Differentiation of Citrus stem "in vitro". J.Amer. Soc. Hort. Sci. Virginia, 97(5):599-603. .

HEINZ, D.J., 1973. Sugar-cane improvement through induced mutations using vegetative propagules and cell culture techniques. In: Induced Mutations in Vegetatively Propagated Plants. Vienna, IAEA, 53-59.

HENSZ, R.A., 1972. Introducing star-ruby-the new Texas grapefruit. The Packer. 1:913.

HORIUCHI, S.; E. YUDA e S. NAKAGAWA, 1976. In vitro culture of young embryo in polyembrionic citrus (1). J. Japonese Soc. Hort. Sci. 45(3): 253-260.

IGLESIAS, L.; H. LIMA e J.P. SIMON, 1974. Isoenzyme identification of zygotic and nucellar seedlings in Citrus. The Journal of lieredity. Washington, 65:81-84.

JUAREZ, J.; L. NAVARRO e J.L. GUARDIOLA, 1976. Obtention de plants nucellaires de divers cultivars de clémentiniers au moyen de la culture de nucelle "in vitro". Fruits. Paris, $31(12): 751-762$.

KATO, YUKIO, 1980. Studies on juice vesicles isolated from mature and immature citrus fruit. J. Japan Soc. Hort. Sci. 49(1):36-40.

KOCHBA, J. e J. BUTTON, 1974. The stimulation of embryogenes is and embryoid development in habituated ovular callus from the "shamout.i" orange (Citrus sinensis) as affected by tissue age and sucrose concentration. Journal of Plant Physiology. Berlin, 73:415-421. 
KOCHBA, J.; J. BUTTON; P. SPIEGEL-ROY; C.H. BORNMAN e H. KOCHBA, 1974. Stimulation of rooting of Citrus embryoids by gibberellic acid and adenine sulphate. Ann. Bot. Oxford, London, 38:795-802.

KOCHBA, J. e P. SPIEGEL-ROY, 1973. Effect of culture media on embryoid formation from ovular callus of 'shamouti' orange (Citrus sinensis). Journal of Plant Breeding. Berlin, 69:156-162.

KOCHBA, J. e P. SPIEGEL-ROY, 1976a. Improvement of plant production in citrus by tissue cultures. The Plant Propagation. 22(1):11-12.

KOCHBA, J. e P. SPIEGEL-ROY, 1976b. The use of Citrus tissue culture for mutation breeding: Effects of plant growth substances and gamma irradiation on embryogenesis. Improvement of Vegetatively Propagated. Plants and Tree Crops through Induced Mutations. Vienna, IAEA, 194: . 83-91.

KOGHBA, J. e P. SPIEGEL-ROY, 1977a. Cell and tissue culture for breeding and developmental studies of Citrus. HortScience. Virginia, USA, $\underline{12}(2): 110-114$.

KOCHBA, J. e P. SPIEGEL-ROY, 1977b. Embryogenesis in gamma-irradiated habituated ovular callus of the "shamouti" orange as affected by auxin and by tissue age. Environmental and Experimental Botany. Oxford, London, 17(2-4): 151-159.

KOCHBA, J. e P. SPIEGEL-ROY, 1982. Progress in selection for sodium chloride, 2, 4-D dichlorophenoxy acetic acid (2,4-D) and streptomycin tolerance in Citrus sinensis ovular callus lines. In: Induced Mutations. in Vegetatively Propagated Plants 11 (Proc. Res. Co-ordination Metting, Coimbatore, 1980). Vienna, IAEA, 77-89.

KOCHBA, J.; P. SPIEGEL-ROY e S. SAAD, 1980. Selection for tolerance to sodium chloride $(\mathrm{NaCl})$ and 2,4-Dichlorophenoxyacetic acid (2,4-D) in ovular callus lines of Citrus sinens is. In: Plant Cell Cultures: Results and Perspectives. 187-192. 
.101.

KOCHBA, J.; P. SPIEGEL-ROY e H. SAFRAN, 1972. Adventive plants from ovules and nucelli in Citrus. Planta. Berlin, 106:237-245.

KORDAN, H.A., 1963. Growth characteristics of Citrus fruit tissue in vitro. Nature. London, 198:867-869.

KORDAN, H.A., 1965. Nucleolar activity and starch synthesis in lemon fruit tissue in vitro. Bulletin of the Torrey Botanical Club. New York, $\underline{\text { 92 }}(1): 21-37$.

LAPINS, K.O., 1973. Induced mutations in fruit trees. Induced Mutations. in Vegetatively Propagated Plants. (Proc. Panel Vienna, 1972), IAEA, Vienna, 329: 1-20.

LESCURE, A.M., 1973. Selection of markers of resistance to base-analogues in somatic cell cultures of Nicotiana tabacum. Plant Sci. Letters. Amsterdam, Netherlands, $1(9): 375$.

LETHAN, D.S:, 1958. Cultivation of apple-fruit tissue in vitro. Nature. London, $182: 473-474$.

MAHESHWARI, P. e N.S. RANGASWAMY, 1958. Polyembryony and in vitro culture of Citrus and Mangifera. Indian J. Hort. Bangalore, India, 15:275-286.

MATSUMOTO, K., 1983. Induction of adventitious buds and their selection for $\mathrm{NaCl}$ - tolerant 1 ines in Rutaceae. Tokyo, 54 p. (Tese).

MELCHERS, G., 1972. Haploid higher plants for plant breeding. Z. Pflanzenzuchtg., 67:19-32.

MITRA, G.C. e H.C. CHATURVEDI, 1972. Embryoids and complete plants from unpollinated ovaries and from ovules of in vivo grown emasculated flower buds of Citrus spp. Bull. Torrey Bot. Club. New York, 99:184189.

MOREIRA, S.; J.T.A. GURGEL e L.F. ARRUDA, 1947. Poliembrionia em Citrus. Bragantia. Campinas, São Paulo, 2:69-106. 
MURASHIGE, T.; W.P. BITTERS; E.M. RANGAN; E.M. NAUER; C.N. ROISTACHER e B.P. HOLLIDAY, 1972. A technique of shoot apex grafting and its utilization towards recovering virus-free citros clones. HortScience. Virginia, $\underline{7}: 118-119$.

MURASHIGE, T. e F. SKOOG, 1962. A revised medium for rapid growth and bioassays with tobacco tissue cultures. Physiol. Plantarum. Kopenhagen 15: $473-497$.

MURASHIGE, T. e D.P.H. TUCKER, 1969. Growth factor requirements of citrus tissue culture. In: CHAPMAN, H.D., Ed. Proc. First Int. Citrus Symp. Riverside, Cal ifornia, 3: 1155-1161.

NAVARRO, L. e J. JUAREZ, 1977a. El imination of Citrus pathogens in propagative budwood. 11 . In vitro propagation. Proc. Int. Soc. Citriculture. 3: $373-987$.

NAVARRO, L. e J. JUAREZ, 1977b. Tissue culture techniques used in Spain to recover virus-free citrus plants. Acta Horticulturae. 78:425-435.

NAVARRO, L.; J. JUAREZ; J.F. BALLESTER; J.A. PINA e C. ORTEGA, 1979. Obtención de plantas nucelares libres de virus de diversas variedades de agrios. del grupo Navel (C. sinensis (L.) Osbeck) por cultivo de ovulos "in vitro". Anales del I.N.I.A. Madrid, Serie Proteccion Vegetal, 12:95-113.

NAVARRO, L.; C.N. ROISTACHER e T. MURASHIGE, 1975. Improvement of shoottip grafting in vitro for virus-free Citrus. J. Am. Sóc. Hort. Sci. Virginia, $100(5): 471-479$.

NITSCH, J.P., 1965. Culture in vitro de tissus de fruits. 11. Orange. Bull. Soc. Bot. Fr. Paris, 112:19-22.

NYBOM, N., 1970. Mutation breeding of vegetatively propagated plants. In: Manual on Mutation breeding. Vienna, IAEA, 119:141-148. 
OHTA, Y. e K. FURUSATO, 1957. Embryoculture in Citrus. Rep. Kihara Inst. Biol. Res. Yokohama, Japão, 8:49-54.

PIERINGER, A.P. e G.J. EDWARDS, 1965. Identification of nucellar and zygotic Citrus seedlings by infrared spectroscopy. Proc. Am. Soc. Hort. Sci. Virginia, 84:226-234.

PAREKH, L.J. e D.A. METHA, 1970. Studies on callus tissue of lemon fruit vesicle (Citrus acida) cultivated in vitro. Current Science. Bangalore, India, 39:513-515.

PARLEVLIET, J.E. e J.W. CAMERON, 1959. Evidence on the inheritance of nucellar embryony in Citrus. Proc. Amer. Soc. Hort. Sci. Virginia, 74:252-260.

RANGAN, T.S.; T. MURASHIGE e W.P. BITTERS, 1968. In vitro initiation of nucellar embryos in monoembryonic Citrus. HortScience. Virginia, 3:226-227.

RANGAN, T.S.; T. MURASHIGE e W.P. BITTERS, 1969. In vitro studies of. zygotic and nucellar embryogenes is in citrus. In: CHAPMAN, H.D., Ed. Proc. First Int. Citrus Symp. Riverside, California, 1:225-229.

RANGASWAMY, N.S., 1958. Culture of nucelar tissue of Citrus in vitro. Experientia. New York, $14(3): 111-112$.

RANGASWAMY, N.S., 1959. Morphogenetic response of Citrus ovules to growth adjuvants in culture. Nature. London, 183(4663):735-736.

RANGASWAMY, N.S., 1961. Experimental studies on female reproductive structures of Citrus microcarpa Bunge. Phytomorphology. New Delhi, $11: 108-127$.

RANGASWAMY, N.S., 1975. Morphogenes is in explants of "Citrus microcarpa" Bunge grown in vitro. Indian J. Exp. Biology. 13(2):213-215. 
SABHARWAL, P.S., 1963. In vitro culture of ovules; nucelli and embryos of Citrus aurantifolia Swingle. In: MAHESHWARI, P. Ed. Plant Embryo -logy - a symposium. Nova Delhi, 239-243.

SCHROEDER, C.A.; E. KAY e L.M. DAVIS, 1962. Totipotency of cells from fruit pericarp tissue in vitro. Science. Washington, 138:595-596.

SCHROEDER, C.A. e C. SPECTOR, 1957. Effect of gibberellic acid and indolacetic acid on growth of excised fruit tissue. Science. Washington $126: 701-702$.

SHARP, W.R. e D.A. EVANS, 1981. Plant tissue culture: the foundation for genetic engineering in higher plants. In: CROCOMO et alii. Genetic. Engineering for Biotechnology (Proc. Int. Symp. on Gen. Eng.), Piracica ba/SP., PROMOCET, 23-28.

SINGH, V.P., 1963. Raising nucellar seedlings of some Rutacea in vitro. In: Plant Tissue and Organ Culture Int. Symp. Delhi, 275-277.

SKOOG, F. e C.O. MILLER, 1957. Chemical regulation of growth and organ formation in plant tissues cultivated in vitro. In: Biological Action. of Growth Substances. 11th Symp. Soc. Exp. Biol. 11:118-131.

SPIEGEL-ROY, J. e J. KOCHBA, 1973a. Mutation breeding in Citrus. In: Induced Mutations in Vegetatively Propagated Plants. Vienna, IAEA, 91-104.

SPIEGEL-ROY, P. e J. KOCHBA, 1973b. Stimulation of differentiation in orange (Citrus sinensis) ovular callus in relation to irradiation of the media. Radiation Botany. 0xford, 13:97-103.

SPIEGEL-ROY, P. e J. KOCHBA, 1975. Production of solid mutants in Citrus, utilizing new approaches and techniques. In: Imp. Veg. Prop. Plants. through Ind. Mut. (Proc. Res. Meeting). Tokai, Japan, IAEA, 73:117-127. 
SPIEGEL-ROY, P. e J. KOCHBA, 1977. Application of tissue culture for plant improvement. In: BARZ, W.; E. REINHARD e M.H. ZENK - Plant Tissue Culture and its bio-technological application. Spinger-Verlag, New York, pp. 404-413.

SPIEGEL-ROY, P. e J. KOCHBA, 1980. Embryogenes is in Citrus Tissue =

Cultures. In: FIECHTER, A. Ed. Advances in biochemical enginnering. Berlin, Springer-Verlag, 27-48.

STARRANTINO, A. e F. RUSSO, 1980. Seedlings from undeveloped ovules of ripe fruits of polyembryonic citrus cultivars. HortScience. Virginia, 15(3): 296-297.

STARRANTINO, A. e. F. RUSSO, 1983. Reproduction of seedless orange cultivars from undeveloped ovules raised in vitro. Acta Horticulturae. Hamburg, Germany, 131:253-258.

STARRANTINO, A.; P. SPINA e F. RUSSO, 1978. Embriogenesi nucellare e sviluppo di piantine in vitro dalle nucelle di alcune specie di agrumi. Gjorn. Bot. Ital. 112:41-52.

STEWARD, F.C.; P.V. AMMIRATO e M.O. MAPES, 1970. Growth and development of totipotent cells. Ann. Bot. Oxford, London, 34:761-787.

TATUM, J.H.; R.E. BERRY e C.J. HEARN, 1974. Characterization of Citrus cultivars and separation of nucelar and zygotic seedlings by thin layer chromatography. Proc. Fla St. Hort. Soc. Talahassee, 87:75-81.

TATUM, J.H.; C.J. HEARN e R.E. BERRY, 1978. Characterization of Citrus cultivars by chemical differentiation. J. Amer. Soc. Hort. Sci. Virginia, $103(4): 492-496$.

TEICH, A.H. e P. SPIEGEL-ROY, 1972. Differentiation between nucellar and zygotic citrus seedlings by leaf shape. Theoret. Appl. Genet. Berlin, 42:314-315. 
.106.

THORPE, T.A.; V.P. MAIER e S. HASEGAWA, 1971. Phenylalanine ammonia-lyase activity in citrus fruit tissue cultured in vitro. Phytochemistry. New York, 10:711-718.

TORREY, J.G., 1966. The initiation of organized development in plants.

Adv. Morphogenesis. 5:39-91.

TUSA, N.; G. CERACI e G. OCCORSO, 1983. Coltura in vitro di ovuli in due specie di agrumi. Riv. Ortoflorofruitt. Italiana. 67:129-138.

VARDI, A. è P. SPIEGEL-ROY, 1982. Plant regeneration from Citrus protoplasts: variability in methodological requirements among cultivars and species. Theor. Appl. Genet. Berlin, 62:171-176.

VARDI, A.; P. SPIEGEL-ROY e E. GALUN, 1975. Citrus cell culture: isolation of protoplasts, plating densities, effect of mutagens and regeneration of embryos. Plant Science Letters. Amsterdam, Netherlands, 4: 231-236.

UNGER, J.W. e K.A. FENG, 1978. Growth and differentiation of juice $\because$ vesicles of orange grown in vitro. Amer. J. Bot. Ohio, 65 (5):511-515. WIDHOLM, J.M., 1978. Problem and selecting mutant cells. Newsletter. 23:2-6. 